\title{
Filozofia Hegla (półrocze zimowe 1904/1905)
}

DOI: http://dx.doi.org/10.12775/RF.2018.008

\section{Wykład pierwszy z 21 października 1904 roku}

[s. 1] Mówić o filozofii Hegla (1770-1831) teraz, kiedy jego filozofia przebrzmiała, kiedy jej czasy minęły, zdaje się bezpowrotnie? To żaden jeszcze argument. Wszak mówimy dzisiaj o filozofii Platona, Spinozy, Leibniza. Wszak to zjawiska historyczne, pominąwszy nawet ewentualnych ich dzisiejszych wyznawców. Jako zjawisko historyczne zasługuje na rozbiór. Ale powie nam ktoś, że w takim razie są ważniejsze, pilniejsze potrzeby historyczne. Są wybitniejsze postacie. A Hegel? Wszak już wkrótce po śmierci jego odzywały się głosy wcale nie pochlebne. Przypominam tylko Schopenhauera. W przedmowie do Die beiden Grundprobleme der Ethik z roku 1840, w 9 lat po śmierci Hegla, nazywa go "całkiem pospolitą głowa, ale wcale niepospolitym blagierem, szarlatanem”"1. A filozofię Hegla nazywa „kolosalną mistyfikacją która jeszcze dostarczy potomności niewyczerpanego tematu do wyszydzenia naszych czasów, pseudofilozofią paraliżującą wszelkie władze umysłu, tłumiącą wszelkie rzetelne myślenie, pseudofilozofia, która dzięki najbardziej zbrodniczemu nadużyciu mowy w miejsce rzetelnego myślenia stawia najbardziej pusta, najbardziej sensu pozbawiona, [s. 2] najbezmyślniejszą - a zatem, jak dowodzi wskutek - najbardziej ogłupiającą frazeologię; pseudofilozofia, która opierając się na pomyśle z palca wyssanym i niedorzecznym, pozbawiona jest w równej mierze podstaw jak wyników, tj. zgoła jest nieuzasadniona, a sama też niczego nie uzasadnia ani nie dowodzi, która przy tym pozbawiona wszelkiej oryginalności jest samą parodią scholastycznego realizmu, a równocze- 
śnie spinozyzmu, - a potwór ten myślowy ma jeszcze, widziane z tyłu, przedstawiać chrześcijaństwo!”2 Dalej powiada, że „Hegel nabazgrał takie brednie, jakich się przed nim żaden śmiertelnik nie dopuścił; kto więc czyta jego najgłośniejszą pracę, Fenomenologię ducha, a nie ma wrażenia, że jest z domu wariatów, ten należy do domu wariatów" ${ }^{\prime \prime 3}$. Trudno o silniejsze wyrażenia. Wszak Platona, Spinozę i wielu innych już tylko „historyczne” znaczenie posiadających myślicieli nawet najbardziej zacięci przeciwnicy poważaja; tutaj zaś widzimy zupełną pogardę, poniewieranie, zmieszanie z błotem, i to przez człowieka, który się przecież na filozofii znał! Schopenhauer odmawia Heglowi wszelką dobrą wiarę! I nie tylko Schopenhauer nie ma, powiedzmy skromnie, szczególnego [s. 3] wyobrażenia o filozofii Hegla, lecz inni także. $\mathrm{Na}$ przykład umysł zupełnie od Schopenhauerowskiego odmienny G. Th. Fechner powiada, że „filozofia Hegla jest w pewnym znaczeniu sztuką oduczenia się prawidłowego wnioskowania" ${ }^{4}$. Więc czyż warto się nią zająć? Otóż przypuśćmy, że wszystkie te zarzuty są całkiem słuszne, to przecież pozostanie prawdą nie mniejszą że ta filozofia blagierska, jak chce Schopenhauer, wywarła w swoim czasie niesłychany wpływ na umysły, a dalsze skutki i następstwa tego wpływu trwają po dziś dzień. W około 1830 roku stanowisko filozofii Heglowskiej w Niemczech dominujące. Największy rozkwit. Był to czas, w którym, jak powiada Haym (Hegel und seine Zeit, str. 4) „,wszelka nauka żywiła się przy suto zastawionym stole mądrości Heglowskiej, gdzie wszystkie wydziały antyschambrowały przed wydziałem filozoficznym, by przyswoić sobie coś niecoś z wysokiego wglądu w absolut i z wszechgibkości słynnej dialektyki, czas, kiedy to było się albo hegelianinem, albo barbarzyńcą i idiota, zacofańcem, pogardy godnym empirykiem; czas, kiedy samo państwo - proszę zważyć - nienajmniejszą podstawę swego poczucia pewności i bezpieczeństwa upatrywało [s. 4] w tym, że właśnie stary Hegel skonstruował konieczność i rozumność organizacji państwowej, czas, gdzie z tego powodu uchodziło w oczach pruskiego ministerstwa wyznań i oświaty za zbrodnię niemal, jeśli ktoś był nie-hegelianinem. Czas ten trzeba sobie uprzytomnić, aby zdać sobie sprawę, co znaczy prawdziwe panowanie systemu filozoficznego. Trzeba sobie przedstawić ów patos i ową siłę przekonania hegelianów z roku 1830, roztrząsających całkiem i najzupełniej poważnie kwestię, co też będzie za dalsza treść dziejów świata, skoro duch świata doszedł w filozofii heglowskiej do swego celu, do swej pełnej samowiedzy!"5 Więc chociażby ta cała filozofia była istotnie potworem myślowym, warto i właśnie dlatego warto sobie zadać pytanie, na czym polega ten jej wpływ? Jakim czynnikom go zawdzięcza? Wszak nic bez przyczyny się na świecie nie dzieje, a wpływ w tych warunkach musiał odpowiadać jakimś potrzebom, a były to potrzeby filozoficzne w tym wypadku. Więc wyjaśnienie, zrozumienie tego zjawiska, należy bezsprzecznie do historii filozofii, 
która musi bezstronnie, przedmiotowo zjawiska badać, rerum cognoscere causas.

Mógłby jednak jeszcze ktoś powiedzieć, że mimo wszystko wykłady [s. 5] o filozofii Hegla są czymś nie tak pilnym, jak na przykład wykłady o filozofach polskich ${ }^{6}$. Jeżeli już ma się mówić o filozofach, których znaczenie naukowe nie jest ustalone, to ci są nam przecież bliżsi. Uznaję w zupełności i tego samego jestem zdania. Tylko że właśnie kluczem do ich zrozumienia jest filozofia Hegla. Najwybitniejsi filozofowie wieku XIX w Polsce to prawie bez wyjątku Hegelianie. Wspomnę cztery najgłośniejsze nazwiska: Józef Kremer, Bronisław Trentowski, Karol Libelt, August Cieszkowski (Gołuchowski był zwolennikiem Schellinga) ${ }^{7}$. Otóż ci filozofowie wywarli wielki wpływ, a chcąc ich naukę, stopień ich samodzielności poznać, musimy wiedzieć, co się już znajduje u wspólnego ich mistrza ${ }^{8}$.

Nie zacznę [zatem] od zarysu biograficznego, którego głównym źródłem pozostanie na zawsze biografia Karola Rosenkranza, jednego ze zwolenników Hegla, profesora w Królewcu, 1805-1879, wydana w Berlinie w 1844 roku, jako suplement do kompletnego wydania dzieł [s. 6] Hegla9 ${ }^{9}$ Rosenkranz miał do dyspozycji całą korespondencję Hegla, także nie wydaną dotąd, spoczywającą razem z innymi rękopisami z jego spuścizny w królewskiej bibliotece w Berlinie ${ }^{10}$. Tutaj wolę nie rozrywać życia i dzieła. W związku [więc] traktować będę. Albowiem rozwój poglądów heglowskich w związku z jego wykształceniem i kolejami życiowemi bardzo bliskim. I dlatego od razu przystępuję do rzeczy.

\section{Młodość Hegla}

([Wykład prowadzony na podstawie:] Haym, 2. Vorlesung ${ }^{11}$ ). Jerzy Fryderyk Wilhelm Hegel, urodzony w Stuttgarcie 27 sierpnia 1770 roku $^{12}$. Rodzina z Karyntii, skąd w wieku XVI do Szwabii, z Wirtembergii emigrowała, gdyż jako przeszła na protestantyzm nie bardzo tam czuła się swojsko wobec prądów silnie katolickich w rządach tego kraju. Ojciec Hegla był herzoglich-würtembergischer Rentkammersekretär, co znaczy mniej więcej sekretarzem ministra skarbu ${ }^{13}$. Ojczyzna jego, to też ojczyzna Schellinga, urodzonego pięć lat później w 1775 roku, również w Wirtembergii, w Leonberg, miasteczku szwabskim. Matkę stracil, mając lat 13. Kochał ją czule i zawsze czule wspominał. Istnieją w największej części jeszcze jego wypracowania szkolne, dalej Dzienniki 1785-87, które prowadził, będąc $\mathrm{w}$ gimnazjum, w którym przebywał lat 10, od 1777 do 1787, więc [s. 7] od 8 do 18 roku życia, wszystko to w Stuttgarcie $^{14}$. Jeśli chodzi o główne prądy umysłowe, które wówczas działały na Hegla, to dwa trzeba wymienić: strarożytność klasyczna i racjonalizm wieku XVIII. Lektura autorów klasycznych szerokie miejsce zaj- 
muje $^{15}$. Przełożył Encheiridion Epikteta i pismo Longinosa Peri hypsous o czynniku wzniosłości ${ }^{16}$. Sofoklesem się zachwycał, zwłaszcza Antygoną ${ }^{17}$. Z zakresu klasycyzmu też tematy mów, które dla ćwiczenia retorycznego wygłaszano. Miał cztery [ulubione]: 1. Rozmowa między Antoniuszem, Oktawiuszem i Lepidusem w sprawie triumwiratu $(1785)^{18}$. 2. O religii Greków i Rzymian $(1787)^{19}$. 3. Niektóre charakterystyczne różnice pomiędzy starożytnymi a współczesno-nowożytnymi poeta$\mathrm{mi}^{20}$. 4. Pożegnalna: Marny stan sztuk i nauk u Turków ${ }^{21}$. Zakończeniem [wnioskiem] było to, że przecież $u$ nas $\mathrm{w}$ Wirtembergii, pod rządami księcia Karola jest bez porównania lepiej. Pod względem treści mowy były korzystnie cenzurowane (felix futurum omen), a pod względem sposobu wygłoszenia mniej. Braki w corporis eloquentia i w vocis firmitas. Braki, które zawsze pozostały i znalazły wyraz w świadectwie jeszcze uniwersyteckim: orator haud magnus. - Obok więc głębokiego przejęcia się wykształceniem klasycznym, o którym przez całe życie mniemał, że musi pozostać podstawą wykształcenia gimnazjalnego, [s. 8] i że ono otwiera drogę do filozofii, prąd racjonalizmu, wieku oświecenia, wtedy wpływa na niego. Tu pamiętać trzeba, że Wirtembergia była tym właśnie krajem południowoniemieckim, który w prądach umysłowych szedł za północnymi. Jak było z reformacja, tak z oświeceniem. Bawaria wprost przeciwnie. A książę Eugeniusz Karol grał rolę małego Fryderyka II, sprzyjając sam oświeceniu. Czytywał więc Hegel głównych autorów tego kierunku: Klopstock, Wieland, Leasing, Nixcolai [Nicolai], Ramler, Capem, Garve, Sulzer ${ }^{22}$. I w tym duchu patrzał też na dzieje starożytne. W mowie o religii Greków i Rzymian twierdzi, że powstała dlatego, iż te narody pozbawione były oświecenia i całkiem w duchu racjonalizmu uważa wierzenia Greków za fabrykat kapłanów, tych ludzi „,chytrzejszych i rozumniejszych, których wybrano dla pełnienia służby bożej"23. Silnie się już wówczas zaznaczający prąd w umysłowości niemieckiej, który miał wyprzeć ducha racjonalizmu, Sturm i Drang, nie pozostawił żadnych wpływów na Heglu, tak samo jak Werterianizm, sentymentalizm. A przecież Werter już w 1774, a Schillera Zbójcy w 1781. Wprawdzie jest ślad w Dzienniczku, że czytał Schillera Verschwörung des Fiesco zu Genua, ale wpływu nie ma ${ }^{24}$. [s. 9] Cały czas swych studiów wyzyskał Hegel sumiennie. Czytywał, robił wypiski, ale nic jeszcze nie wskazywało na późniejszą jego rolę. Tymczasem występują [tu] pewne rysy, które w jego filozofii później odnajdziemy. Hegel był, jako uczeń gimnazjalny, pedantyczny, filisterski, tym, co Niemcy nazywają altklug. To wynika z jego Dziennika. Dla przykładu kilka ustępów: (po części po niemiecku, po części, dla wprawienia się w stylu, po łacinie). Czwartek 21 lipca 1785: „Chodziłem na spacer z panem Clossem. Gdy przechodziliśmy koło fossy, (über den Graben) uderzano w wielki dzwon z powodu pogrzebu p. radcy rządowego Schmidlina. Równocześnie zaczęto grać na trąbonach z wieży ratuszowej, moles propinqua nubibus arduis. Ponury, 
uroczysty, powolny dźwięk dzwonu i smutny dźwięk trombonów wywarły na mnie tak wzniosłe wrażenie, że nie mogę go opisać, zwłaszcza że przy tym widziałem z czasem z daleka powozy i myślałem o żalu osieroconych" ${ }^{25}$. Piątek 22 lipca: „Znowu chodziłem z panem Clossem na spacer, egzaminował mnie o bryłach foremnych i nieforemnych"26.Albo niedziela 31 lipca: „Deficiente alia quadam materia, Adrasti calamitates enarrabo. Adrastes, Phrygiae regis filius etc." ${ }^{27}$ - Albo: [s. 10] poniedziałek 8 sierpnia: "Silentio non praetermittendum sane esse in hac factorum enarratione, in Collegio Rev. Dni Prof. Clessii praestantissimas Livii historias sub Dei auspiciis nos hodie inchoasse. Libata est a summe rev. Professore Livii vita, de qua quidem pauca ad nos pervenerunt. Quae equidem didici, paucis commemorabo. Livius Patavinus sub Augusto floruit etc." 28 - A innym razem zapisuje, jakie i za ile książki zakupił sobie (autorów łacińskich), innym razem o pożarze nocnym, przy którym z ojcem udał się na ratunek; ale znajdują się także refleksje natury naukowej, filozoficznej. Na przykład o stosunku przesądu do wiary religijnej, o istocie pragmatycznego sposobu pisania historii, - jednym słowem malują nam Hegla gimnazjalistę jako młodzieńca oddanego studiom, nauce, obiektywnie, bez własnych w tym lub owym kierunku porywów, lecz przyjmującego, wchłaniającego w siebie wiedzę. I to wiedzę najrozmaitszą: filologię, ale niemniej matematykę, historię ${ }^{29}$. Pewnego rodzaju oschłość charakterystyczna dla tego umysłu. I to zgadza się z jego systemem filozofii, który także tę trzeźwość, tę oschłość w sobie nosi, w swej konstrukcji. To sparagrafowanie całego bytu za pomocą szczegółowego belkowania logicznego już [s. 11] tutaj preformowane. A dalej druga cecha: Hegel na pograniczu albo raczej w punkcie krzyżowania się filozofii i uczoności, erudycji. Jak Arystoteles pragnął wszelką wiedzę objąć i posiąść i usystematyzować; stąd właśnie ten encyklopedyczny charakter. A trzecie: historyzm. Ta receptywność umysłu, przechodząca kolejno wszelkie fazy i okresy rozwoju ludzkości, także w systemie się odbiła. Toteż w skład systemu heglowskiego wchodzi właśnie rozwój historyczny myśli ludzkiej. Jest ta cała filozofia jednym słowem systemem encyklopedycznym, opartym na motywach logicznych i przesiąkniętym historycznymi punktami widzenia.

\section{Wykład drugi z 28 października 1904 roku}

Ale nim do tego doszło, jeszcze długa droga, która teraz prowadzi nas na uniwersytet $\mathrm{w}$ Tybindze, gdzie 27 października 1788 roku immatrykulowany jako słuchacz teologii. Mieszkał w seminarium, na miejscu funduszowym książęcym; kurs nauk trwał w uniwersytecie 5 lat, pierwsze dwa głównie filozofia, trzy teologia. Co do zewnętrznego toku w tym czasie, po dwóch latach filozoficznych stopień magistra (1790) na 
podstawie obrony rozprawy jednego z profesorów pt. De limite officiorum humanorum seposita animorum imortalitate ${ }^{30}$. Po trzech latach teologii stopień kandydata, przy czym bronił rozprawy innego profesora De ecclasiae Wirtembergensis [s. 12] renascentis calamnitatibus (1793) ${ }^{31}$. Same wykłady uniwersyteckie wielkiego wpływu nie wywarły. Nie teologia, a filozofia wolffiańska. Tylko że, tak w teologicznych, jak filozoficznych wykładach, dawał się uczuwać już wpływ Kanta przynajmniej o tyle, że profesorowie z nim polemizowali. I może ta okoliczność skłoniła Hegla do lektury Krytyki czystego rozumu, którą poznał w 1789. Równocześnie ze znajomością Kanta zaczęły dochodzić odgłosy rewolucji francuskiej. Otóż Kant i rewolucja z jednej strony, a z drugiej strony dwaj koledzy wywołują zmianę zasadniczą w poglądach Hegla. Tymi kolegami [są] Hölderlin i Schelling ${ }^{32}$. Hölderlin - rówieśnik, Schelling - pięć lat młodszy, ale bardzo szybko się rozwijający umysł. Tenże wzbudził w nim zamiłowanie do filozofii, podsycał je; Hölderlin natomiast świat klasyczny dopiero właściwie mu otworzył i uczynił zrozumiałym. Mianowicie w czasie uniwersyteckim Hegel już nie zadowalał się racjonalizmem trywialnym, filozofią popularną oświecenia. Prawa uczucia i serca wydały mu się pierwszymi. Lektura Jacobiego, twórcy tzw. filozofii wiary, uczucia; a niemniej także to konkretne pojmowanie rozumnego, racjonalnego urządzenia życia, które się przebijało w rewolucji francuskiej. Polityka w seminarium. [s. 13] Na zebraniach w czasie rekreacji i nauki zamiast czytać autorów politykowano; entuzjazm: to podsycane studentami z Mömpelgard, poza Renem położonej enklawy wirtemberskiej. Starcia rozmaite. Ci z Mömpelgardu bowiem przeciwnikami rewolucji. Więc pojedynki, dyscyplinarki ${ }^{33}$. - Więc pamiętajmy: świat helleński Hölderlin. Odwrócenie się od zimnego racjonalizmu. Głębsze ujęcie zadań rozumu, a przy tym sentymentalizm pewien, uznanie praw uczucia. W takim stanie ducha opuszcza uniwersytet. - Co do jego osoby, to i w uniwersytecie na ogół spokojny, przykładny (wyjątki, jak opóźnienie ze spaceru), tak że przezwano go staruszkiem. Ale był lubiany, od kolegów nie stronił, pił z nimi, a nawet kochał się w córce byłego profesora, imieniem Augustyna ${ }^{34}$. W albumie jego, w sztambuchu, wiele bardzo od jego przyjaciół aluzji do tej miłości, która zdaje się nawet ważniejsza, a wzajemnością się nie cieszyła. - Koniec studiów, teraz w życie, a przygotowany był, jak widzieliśmy, do zawodu duchownego. - Ale zostać zwykłą koleją losów wikarym, a potem proboszczem, nie uśmiechało mu się. Brakło mu potrzebnego patosu, a nadto na kaznodzieję nie był stworzony. Orator haud magnus.

([Wykład prowadzony dalej na podstawie:] Haym, Vorlesungen III $^{35}$ )

Więc [s. 14] wrócił jesienią 1793 po ukończeniu uniwersytetu na krótki czas do domu ojcowskiego do Stuttgartu, a potem przyjął po kilkutygodniowym zaledwie popasie $\mathrm{w}$ domu posadę guwernera w Bernie szwajcarskim, gdzie miał wychowywać dwie córeczki i siedmioletnie- 
go podówczas syna niejakiego pana Steigera, bogatego i wpływowego patrycjusza berneńskiego. Pozostał w tym domu trzy lata (jesień $1793-$ jesień 1796), a obok obowiązków guwernerskich wypełniają jego czas studia i próby samodzielnych prac na polu teologiczno-filozoficznym ${ }^{36}$. Pozostaje on w tym okresie głównie pod wpływem Kanta, Fichtego i Schellinga. Z pism Kanta interesuje go przede wszystkim Die Religion innerhalb der Grenzen der blossen Vernunft, wyd. 1793 i przedtem mu już znana, a teraz ponownie studiowana Krytyka rozumu praktycznego. Zasadniczą zaś myślą tych dzieł jest oparcie przekonania o istnieniu Boga i całego szeregu przekonań religijnych, chrześcijańskich na potrzebach moralnych duszy ludzkiej. Fichte, urodzony w 1762 roku, więc o 8 lat od Hegla starszy, wydał bezimiennie w 1791 roku rzecz Versuch einer Kritik aller Offenbarung, które uważano jakiś czas [s. 15] za dzieło Kanta, a sam Fichte już w 1794 został profesorem filozofii w Jenie. W maju w tymże roku [wyszło jego] Grundlage der gesamten Wissenschaftslehre ${ }^{37}$. Z nim Hegel nie był w stosunku osobistym natomiast z Schellingiem, kolegą z ławy uniwersyteckiej. Schelling już wydawał szereg pism filozoficznych, gdy Hegel jeszcze nic nie publikował. Pierwsze prace filozoficzne Schellinga z roku 1795 Ueber die Möglichkeit einer Form der Philosophie überhaupt i Vom Ich als Princip der Philosophie oder über das Unbedingte im menschlichen Wesen, jako też w 1896 wydane Philosophische Briefe über Dogmatismus und Kriticismus - czytał Hegel w Bernie ${ }^{38}$. - Zarówno Fichte, jak Schelling, uważali się za kontynuatorów Kanta, przynajmniej zrazu; sądzili, że sami są między sobą zgodni w swych poglądach. Hegel wniknął $\mathrm{w}$ prace Fichtego drogą prac Schellinga, którego bez najmniejszej zazdrości cenił wysoko. Wszak pisze Schellingowi, gdy tenże mu przysłał dwie pierwsze swe prace: „Nie możesz się po mnie spodziewać uwag o twej książce; jestem tutaj tylko terminatorem" ${ }^{39}$. Wyraża się o pracy z największym zachwytem, uważa ją za epokową. Później nie tylko ten stosunek osobisty się popsuł, lecz Hegel [s. 16] sam postrzegł, że między filozofią Fichtego i Schellinga powstają coraz liczniejsze i dalej sięgające różnice; stąd potem mu się własne zadanie filozoficzne krystalizuje, tak że jego filozofia jest dalszym rozwojem Schellingowskiej, młodszego latami kolegi. Słusznie porównuje Kuno Fischer ten stosunek ze stosunkiem między Anaxagorasem i Empedoklesem, scharakteryzowanym przez Arystotelesa: „Anaxagoras był helikia proteros, ergois hysteros”. Tak też Hegel i Schelling ${ }^{40}$.

\section{Wykład trzeci z dnia 4 listopada 1904 roku}

Wszelako w Bernie nie filozofia [była] jako taka na pierwszym planie jego studiów, lecz zagadnienia teologiczno-filozoficzne. Z uniwersytetu wyniósł wiedzę teologiczna, religię pozytywną. Teraz prądy nowe 
filozoficzne, poetyckie, a także hellenistyczno-pogańskie oddziałują coraz żywiej, tym więcej, że z Hölderlinem pozostaje w korespondencji ${ }^{41}$. Stąd ferment $\mathrm{w}$ duszy, pragnący wyrównania. To dążenie wyraża się w szeregu prac, niewydanych drukiem, jak np. Życie Jezusa (napisane 1795); rozprawa pod tytułem (przypominającym pracę Fichtego), mianowicie Kritik des Begriffs der positiven Religion (1796). Następnie szereg [s. 17] takich: Historia żydów; Przeznaczenie i pogodzenie się z nim; Miłość i wstydliwość; Syn Boży i człowieczy; Wieczerza; Cud; Chrzest"2. Rozprawy i rozprawki te wyjawiają nam, że Hegel z tego fermentu pomiędzy wiarą pozytywną a religią racjonalną, filozoficzna, pomiędzy wiarą kościelną a religią $w$ granicach samego rozumu skłonił się ku stronie drugiej. A w tym zupełnie zgodny z Schellingiem. Gotów razem z Schellingiem porwać się do walki przeciw religii pozytywnej, przeciw kościelnym dogmatom i ich ciężarowi, przytłaczającemu wolną i swobodną myśl ludzką (z roku 1796 Oda do Hölderlina, przypomina mu, by być wiernym postanowieniu „Der freien Wahrheit nur zu leben, Frieden mit der Satzung, die Meinung und Empfindung regelt, nie, nie einzugehn"43. - A wiemy, że zrazu uważał religię pozytywną za wymysł kapłanów, będących na usługach władzy świeckiej). Coraz silniej zarysowuje i uprzytomnia mu się przeciwieństwo między wiarą kościelną i między wiarą opartą na postulatach etycznych, czyli, jak mówi Kant, teologią moralną. Ale właśnie to zwrócenie całej swej uwagi na to przeciwieństwo zaczyna go oddalać od Schellinga. Schelling uważa teologię jako taką za rzecz już przezwyciężoną i zarzuca coraz bardziej zajmowanie się tymi problematami, nawet z ich strony historycznej. Pisze do Hegla: „Któż chciałby się zakopywać w pyle starożytności, gdy bieg czasu każdej chwili go podnieca i pobudza i ze sobą porywa?" ${ }^{44}$ I dlatego zwraca się wyłącznie Schelling ku [s. 18] filozofii. Zaprzyjaźnia się z poglądami Spinozy i wkrótce pisze Heglowi, zdumionemu nieco, że nowa filozofia sięga dalej, aniżeli do idei Boga osobistego ${ }^{45}$. Hegel to wszystko śledzi z wielkim zainteresowaniem, nawet sympatyzuje z tymi poglądami, ale sam ku ich opracowaniu się nie zwraca, lecz tkwi w zagadnieniach bardziej konkretnych i praktycznych ${ }^{46}$. Zamiast posuwać się dalej z punktów, zdobytych Kantowskim krytycyzmem, usiłuje określić bliżej stosunek tych wyników Kantowskiego krytycyzmu do faktu, że istnieje bądź co bądź religia i wiara pozytywna. Skąd się ona bierze, skoro przecież na poczuciu etycznym oparta jest religia? Dlaczego człowiek do tej teologii moralnej konstruuje cały aparat objawienia dogmatów i obrzędów? Skąd ta pozytywna treść wszelkiej, a zwłaszcza chrześcijańskiej religii? A wyjaśnienia tych kwestii znowu nie szuka na drodze spekulacji filozoficznej, lecz na drodze historycznej. I dlatego zajmuje się życiem Chrystusa, twórcy chrześcijaństwa ${ }^{47}$. W osobie twórcy swego chrześcijaństwo religią moralną; w rozwoju swym staje się religią pozytywną. A dlaczego? Primo, bo Chrystus głosił swą naukę Żydom, którzy od razu wtłoczyli 
ją w formę [s. 19] religii pozytywnej, bo innej religii nie znali. Secundo, nauka Chrystusa była głoszona szczupłej garstce ludzi w specjalnych warunkach historycznych skoro stała się nauką całego społeczeństwa, ujętego w formy państwowe, także i nauka ta musiała przyjąc organizację analogiczną ze wszystkimi następstwami tego stanu rzeczy. Samą osobę Chrystusa pojmuje Hegel historycznie, w duchu racjonalizmu, jako człowieka w rodzaju Sokratesa, nauczyciela ludzkości ${ }^{48}$. Ale ten racjonalizm złagodzony czynnikami mistycznymi; przelotnie czytywał dzieła mistyków średniowiecznych; ale więcej od tego wpływu zaważyła w tym kierunku pojmowania nauki Chrystusowej jako czystej nauki miłości, owianej tchnieniem gorącego ciepła i przeczucia czegoś poza tutejszym światem leżącego, czegoś, co wskazuje w nieskończoność, w czym znowu zgodnie z Kantem z etyki wyrasta nieśmiertelność. Że ten mistycyzm nie wybujał bardziej, należy przypisać stanowisku Hegla względem świata starożytnego, w którym w mistycyzmie greckim, eleuzyńskim miał przykład mistycyzmu wcale się od życia nie odwracającego $^{49}$. I mając wzrok zwrócony ku starożytności, stawia sobie Hegel [s. 20] dalsze pytanie, znowu historyczne: Jak wytłumaczyć zwycięstwo religii pozytywnej chrześcijańskiej nad światem wierzeń starożytnych, tym więcej, że ta chrześcijańska religia była w swej postaci pozytywnej czymś sztucznym, myślowo i narodowo obcym światu starożytnemu? I jak przedtem w stosunku Chrystusa do swego otoczenia, tak teraz w stosunku chrześcijańskiego okresu starożytności do pogańskiego szuka odpowiedzi: (Wierzenia religijne Greków i Rzymian były wierzeniami dla ludów wolnych. Ludy te żyły dla swej wolności, dla swych wolnych rzeczypospolitych. To życie było im najwyższym i myśl o tych zadaniach życie im wypełniała. W duszy i sercu swym nosiły miłość wolności i swego państwa. Gdy jednakowoż ta wolność i państwa zaczęły ginąć, ustępując miejsca cezaryzmowi, zabrakło tego, co wypełniało im życie i dawało mu wyższą, wzniosłą treść. I wtedy stali się skłonni przyjąć religię, która pustkę tę obiecywała im wypełnić, jeżeli nie zaraz, to przynajmniej widokami życia przyszłego. Boga, którego nosili przedtem W sercu, umieścili teraz poza sercem, poza światem $)^{50}$. „Uprzedmiotowienie Bóstwa szło ręka w rękę z zepsuciem i niewolą ludzkości i [s. 21] jest właściwie tylko objawem tego ducha czasu" - powiada Hegel ${ }^{51}$. I tak samo skarbiec moralności, drzemiący w sercu ludzkiem przemienił się w sumę boskich praw i przepisów. Dopiero w naszych czasach, konkluduje, zaczęto znowu te skarby rewindykować i z nieba reklamować jako własność człowieka. Ma tu na myśli oczywiście znowu teologię moralną i autonomię praktycznego rozumu Kanta. - Tak więc mamy tutaj klucz do zrozumienia, jak świat chrześcijańsko-mistyczny łączy się u Hegla ze światem klasyczno-pogańskim. Pierwotna nauka Chrystusa w oczach Hegla istotnie pokrewna ze światem klasycznym; życie pogańsko-klasyczne i życie Chrystusa było życiem pięknym, ludzkim, ale ze względu 
na swą swobodę i bogatą treść zarazem boskim. A stosunek Chrystusa do religii kościelno-chrześcijańskiej ten sam, co świata pogańsko-klasycznego do świata kościelnego poglądu, owej religii kościelno-chrześcijańskiej ${ }^{52}$. W tym złączeniu chrześcijaństwa i pogaństwa przechylają się jednak sympatie coraz wyraźniej na stronę klasycznego pogaństwa. Moment estetyczny coraz wyraźniej występuje. Stan żydostwa w chwili zjawienia się [s. 22] chrześcijaństwa nazywa stanem kompletnej brzydoty. I dlatego „wielka tragedia narodu żydowskiego nie jest grecka; nie może wzbudzić obawy i litości, albowiem obawa i litość wypływają z przeznaczenia nieuchronnie błądzącej istoty pięknej"53. A zatem tłem dla zrozumienia historii żydostwa jest tragedia grecka, pojęcia przeznaczenia, strachu, czyli obawy i litości, a nawet Chrystusa pojmuje jako człowieka, walczącego z przeznaczeniem żydostwa, usiłującego żydostwo podnieść wyżej; walczy jednak miłościa, i dlatego w walce ulega swemu przeznaczeniu. Miłość tu nie może być bronią zwycięską. Tak więc daleko odbiegł teolog młody od zakresu myśli, które mogły go były pokierować na drogę zawodu i powołania teologicznego. Stał się wielbicielem świata klasyczno-pogańskiego i tym światem mierzył chrześcijański ${ }^{54}$.

([Wykład prowadzony dalej za] Haymem, Vorlesungen IV ${ }^{55}$ ).

Tak więc w okresie pobytu w Szwajcarii Hegel w dwojakim kierunku przede wszystkim umysł swój rozwinął: w historycznym i w religijnym. W obu kierunkach znacznie dojrzał i pogłębił swe poglądy. W tym pierwotnym racjonaliście, pedantycznym nieco i suchym odezwało się zrozumienie pełni życia, na wzorze helenizmu, uczucia gorącej miłości na tle [s. 23] postaci Chrystusa; a czynnik estetyczny także niemałą odgrywał w tym rolę. Ale i jeszcze w jednym bardzo odmiennym kierunku budziło się teraz zainteresowanie: kwestie państwowo-administracyjne i polityczne. Napisał rozprawkę o zmianach, jakie w organizacji wojskowej pociąga za sobą zmiana formy rządu z monarchicznego na republikański; nadto szczegółowo studiował ustawodawstwo kantonu berneńskiego co do przepisów podatkowych ${ }^{56}$. - Wszystkie te studia, myśli, zajęcia nie potrafiły go jednak pogodzić z pobytem w Bernie; toteż z radością powitał w jesieni 1796 list Hölderlina, który miał posadę guwernera we Frankfurcie nad Menem i w tym samym mieście dla Hegla takąż posadę wynalazł ${ }^{57}$. Opuściwszy w jesieni 1796 Berno, udał się do Stuttgartu, aby czas jakiś w domu pobyć, u Ojca i siostry, a w styczniu 1797 objął posadę we Frankfurcie w domu niejakiego p. Gogela, bogatego kupca ${ }^{58}$. 


\section{Wykład czwarty z dnia 11 listopada 1904 roku}

Zaczyna się czwarty okres życiowy: 1. Młodość do uniwersytetu; 2. Uniwersytet; 3. Berno, 4. Frankfurt. W 1. okresie w gimnazjum, był polihistorem; w 2. republikaninem, w 3. teologiem i historykiem, w 4. zaś okresie, który trwał lat cztery, [s. 24] od stycznia 1797 do końca roku 1800 krystalizuje się wszystko w kierunku filozoficznym, spekulatywnym $^{59}$. W Frankfurcie też powstał pierwszy zarys, szkic jego systemu filozofii ${ }^{60}$. Ale musimy śledzić fazy tej genezy, gdyż geneza ta zarazem też oświetla kierunek i zasadniczy punkt wyjścia jego filozofii. Zrazu nic jeszcze na to nie wskazywało. Miasto Frankfurt, jego przeszłość, dalej sąsiedztwo tylu wypadków w walkach napoleońskich ważnych zwróciło jego uwagę na stosunki i kwestie polityczne. Czytuje pisma treści politycznej, prawniczej, społecznej. Jego ojczyzna ściślejsza, Wirtembergia, staje mu się przedmiotem studiów krytycznych i pisze: Ueber die neusten inneren Verhältnisse Würtembergs, besonders über die Gebrechen der Magistratsverfassung, 1798 (nie drukuje, bo mu odradzają) ${ }^{61}$. I niezawodnie już tutaj, w Frankfurcie zajmowały go i układały się myśli inne, które spisał już dopiero po opuszczeniu Frankfurtu, około roku 1801, ale które tak samo jak tamta rzecz o Wirtembergii, wyrażają się o stosunkach politycznych całych Niemiec bardzo pesymistycznie ${ }^{62}$. „Niemcy nie [s. 25] są państwem" ${ }^{\prime 3}$ - oto zasadnicza myśl tej rozprawki: brak organizacji, wybujały indywidualizm jednostek i państewek, brak silnej władzy, a w środkach zaradczych okazuje się zależnym od lektury Machiavellego ${ }^{64}$. Dowodem, że te wszystkie myśli już w Frankfurcie go zajmowały, jest fragment, niewątpliwie w owym czasie spisany, a zawierający charakterystykę politycznego położenia ówczesnych Niemiec. Zdaje sobie sprawę, że dawne stosunki polityczne i społeczne oraz ekonomiczne zostały zachwiane, że nowe ich ukształtowanie musi nastąpić; obecnie zaś stan rzeczy chaotyczny, bez steru, wszystko kotłuje i fermentuje, i w tym ujawnia się obecnie wielka słabość polityczna i społeczna Niemiec. Wszędzie dysonans, sprzeczność między tym, co jest, a czego ludzie pragną. Brzemię stosunków dawnych przygniata wszystkich; wszyscy pragną czegoś lepszego, przez cały świat daje się odczuwać tęsknota za czymś nowym, innym. W tym ogólnym poczuciu leży też rękojmia, że dane stosunki nieznośne ustaną i że sprzeczność między ideałem i życiem zostanie usunięta. Tak, jak teraz jest, pozostać nie może. [s. 26] Wszystko, co istnieje, utraciło wszelką doniosłość i godność. Stało się „czymś czysto negatywnym"65. I teraz następuje ustęp znamienny: „lepsze życie owiało swym tchnieniem te czasy; a popęd ku niemu podtrzymuje się tym, co działają wielkie charaktery jednostek, ruchem, panującym w całych narodach, obrazami, które tworzą poeci o przyrodzie i o przeznaczeniu; ograniczeniom wszelkim naznacza kres 
metafizyka, określając zarazem ich konieczność w związku całości”"66. Otóż tu mamy cenne bardzo dla genezy jego filozofii wyznanie. Powołuje się na poetów, powołuje się na ducha czasów, i wyraża przekonanie, że metafizyka potrafi zakreślić kres ograniczeniom, które jako ciężar życiowy dają się we znaki, że potrafi dowieść, iż te ograniczenia są konieczne jako składniki całości pięknej i wspaniałej ${ }^{67}$. Marzy więc o metafizyce, która szłaby równolegle z poezją Goethego i Schillera, z duchem czasu, a to znaczy, że ta metafizyka tak samo, jak te dwa czynniki ma wyrównać sprzeczności pomiędzy ideałem i życiem. Poezja czyni to, godząc je za pomocą fantazji; duch czasu, tj. sam bieg wypadków z tego ducha wynikający, doprowadzi do jakiegoś nowego ukształtowania rzeczywistości, zgodniejszego od danego z pragnieniami człowieka; metafizyka zaś, którą ma Hegel na myśli, pogodzi ideał z życiem w ten sposób, że rzeczywistość pokaże nam pod idealnym punktem widzenia [s. 27]. Aby zaś tę rzeczywistość pod tym idealnym punktem widzenia przedstawić i niejako tym sposobem widzenia ją przeniknąć, sam ten sposób widzenia musiał być jasno skrystalizowany i zupełnie niejako sformułowany. Otóż podstawę do tego znowu ów kierunek myśli, który od czasów uniwersyteckich coraz głębiej się wrażał w jego duszę: kierunek teologiczny albo, jak teraz lepiej po okresie berneńskim powiedzieć możemy, kierunek filozofii religii. Toteż w Frankfurcie przerabia swój rękopiśmienny traktat o tym, co nadało chrześcijaństwu charakter religii pozytywnej ${ }^{68}$. Pisze nowy wstęp. Znacznie modyfikuje swe stanowisko. Już nie jest racjonalistą czystej krwi, którym był względem pozytywnej treści religii. Ta treść o tyle tylko musi być poddana krytyce, o ile „pretensje swe podnosi wbrew rozumowi i rozsądkowi"69. Gdzie to nie zachodzi, nieuzasadnioną jest pretensją rozumu krytykowanie tej treści pozytywnej. Gdzie to nie zachodzi, nieuzasadnioną jest pretensja rozumu krytykowania tej treści pozytywnej. Trzeba oceniać religię z punktu widzenia historycznego. Nawet rzeczy najbardziej sprzeczne z rozumem wtedy, gdy w nie wierzono, były czymś naturalnym i zgodnym z duchem ludzkim. Stały się złem z chwilą gdy ludzkość się zmieniła, w rozwoju swym wyżej postąpiła. - A czym [s. 28] jest w takim razie religia, skoro mimo wszystko treść jej pozytywna, dogmatyczna zmianie ulega? Odpowiedział na to pytanie w Bernie historycznie, analizując życie i naukę Chrystusa; teraz spekulatywnie, filozoficznie zagadnienie to rozważa: rozważanie to musi, to są jego słowa: „przemienić się w metafizyczny rozbiór stosunku tego, co skończone, do tego, co nieskończone"70. Z całą więc energią przystępuje do tego rozbioru, dokonuje go na tle pojęcia, które już dawniej w teologiczno-historycznycch jego rozbiorach zasadniczą odgrywało rolę: pojęcia życia ${ }^{71}$. Wszak życie Chrystusa, jako życie miłości, życie pogańskie jako życie wolne dawało mu klucz do zrozumienia religii Chrystusowej i religii helleńskiej. I teraz życie da mu ten klucz do rozbioru metafizycznego. Człowiek jest życiem jednost- 
kowym, cząstką życia w ogóle, życia powszechnego, a przecież czymś innym, aniżeli to całe nieskończone otaczające go życie jednostek i ustrojów. Otóż o ile życie ludzkie jest myślące, potrafi w tym całym chaosie otaczającego go życia dopatrzyć się życia w ogóle, życia absolutnego, nie ograniczonego, nie podległego zniszczeniu i śmierci; życie to nazywa się Bogiem. A to wzniesienie się [s. 29] od życia skończonego, ograniczonego, do nieskończonego, nieograniczonego, to właśnie jest religia. Wtedy też wszechświat inaczej się przedstawia. Przedstawia się jako jedność ożywiona, jako nieskończone wszechżycie. Rozum wprawdzie, rozpatrując rzeczy, wnosi w nie przeciwieństwa; nie może rozważać rzeczy tylko z punktu widzenia życia, lecz także jego przeciwieństwa, śmierci; ale tej konieczności wnoszenia w rozważanie rzeczy przeciwieństw religia nie podlega; albowiem ona jest właśnie wzniesieniem się życia skończonego do nieskończonego. Dlatego filozofia musi się kończyć religią72.

\section{Wykład piąty z 18 listopada 1904 roku}

Myśli te skreślił Hegel z datą 14 września 1800 roku, a więc na krótki tylko czas przed opuszczeniem Frankfurtu ${ }^{73}$. Tam więc zadanie filozofii już mu się skrystalizowało. Albowiem już tylko mały krok do samego systemu filozofii. Krok ten zrobiony z chwila, gdy Hegel zapomina o tym, co sam o stosunku filozofii do religii powiedział. Filozofia musi się kończyć religia, albowiem filozofia nie jest w stanie ująć nieskończonego życia; może tylko wykazać skończone życie i na podstawie rozumowej domagać się jego uzupełnienia. Tak był powiedział. Ale przy tym nie wytrwał. Jego cała natura [s. 30], a zarazem różne wpływy wykształcenia dotychczasowego popchnęły go o krok dalej: nie wystarcza mu, że zrozumiał, czym jest religia, jaka jest jej istota. Ta myśl, że człowiek w skończonych formach życia dopatruje się życia nieskończonego, spokoju mu nie daje. Pragnie się naprawdę dopatrzeć. Pragnie to dopatrywanie się przeprowadzić. Z faktu, że rozum podjął religijne wzniesienie się ducha ku życiu nieskończonemu, wyłania się w jego rozmyślaniach pojmowanie samego tego nieskończonego życia. Filozofia, tłumacząca istotę religii, upatrując ją we wznoszeniu się od życia skończonego do nieskończonego, zaczyna tłumaczyć samo to wznoszenie się. Filozofia dopatruje się w wszechświecie, w życiu skończonym Boga, życia nieskończonego; zaczyna więc refleksyjnie czynić to, co uczuciowo czyni i wyłącznie czynić powinna religia. I tym sposobem powstaje w głowie Hegla pierwszy zarys systemu ${ }^{74}$, o którym sam pisze 2 listopada 1800 roku do Schellinga: „Tok mego wykształcenia naukowego, które rozpoczynało od podrzędnych potrzeb ludzkich, nieuchronnie popchnął mnie ku nauce samej, [s. 31] a to, co w wieku młodzieńczym było mi ideałem, musiało przybrać charakter refleksji, musiało się stać zarazem systemem"75. 
Tak więc sam Hegel nam źródło swego systemu wskazał jasno, a cokolwiek o genezie tego systemu powiedziałem, miało tylko być niejako komentarzem do tego krótkiego zdania. Widzimy stąd zarazem, jak różne to źródło u Hegla w porównaniu z Kantem lub chociażby z Fichtem. Kanta ku filozofii popycha bądź co bądź potrzeba znalezienia niewzruszonych podstaw wiedzy. Sumienność naukowa badacza. Hegla ku temu popycha potrzeba ułożenia sobie całości świata i życia w jakąś formę uporządkowaną. Popęd raczej poetycki aniżeli naukowy; popęd ujęcia wszechświata według pewnego ideału, typu gotowego w duszy Hegla. Niedaremnie świat klasyczny, odnowiony w poezjach Schillera i Goethego oddziaływał na Hegla. Ta pełnia życia helleńskiego, pogłębiona religijnością chrześcijaństwa, staje się przewodnim motywem metafizyki Heglowskiej. Jak Schiller i Goethe zhelenizowali przyrodę i przeznaczenie ludzkie, tak Hegel zhellenizował metafizykę $e^{76}$. Tylko mniej estetycznie. Ale i on pod względem merytorycznym każe nam wierzyć, że wszelkie braki i niedoskonałości naszych form życia, naszej wiedzy, [s. 32] naszej wiary, wyrównują się, skoro je jako cząstki nieskończonego wszechżycia zaczniemy rozważać!

Nim nakreślę zasadnicze myśli jego pierwszego szkicu filozofii, jeszcze kilka dat z życia zewnętrznego. Na ogół czuł się Hegel w Frankfurcie zadowolony znacznie więcej aniżeli w Bernie. Tylko katastrofa, której uległ jego przyjaciel Hölderlin we wrześniu 1798, znowu rzuciła cień na jego życie ${ }^{77}$. Wkrótce większe nieszczęście: śmierć ojca, który umarł nagle 14 stycznia 1799 roku; pozostało nieco majątku; rodzeństwo, tj. dwaj bracia Hegla i siostra wraz z nim podział przeprowadzili, tak że pozostało mu około $3000 \mathrm{złr}^{78}$. Zaczyna więc już całkiem konkretnie myśleć o obraniu kariery akademickiej. Pragnie się habilitować w Jenie, w owej stolicy ówczesnej filozofii niemieckiej. Pisze po kilkuletniej przerwie w korespondencji do Schellinga ów list z 2 listopada 1800 roku, prosząc o informacje co do Bamberga, gdzie Schelling niedawno bawił, a gdzie Hegel pragnie jakiś czas w zupełnym spokoju przygotować się do habilitacji ${ }^{79}$. Wbrew temu zamiarowi udaje się wprost do Jeny z Frankfurtu i przybywa tam w styczniu 1801 roku. Pozostał sześć lat; przyszedł z zarysem systemu w głowie. Jakiż to system?

[s. 33] ([Wykład w dalszym ciągu prowadzony za] Haymem, V. Vor..$^{80}$ )

Spisany [został] na 132 arkuszach w czasie frankfurckim; gotów był z tym, gdy pisał do Schellinga ów list ${ }^{81}$. Rękopis, jak wszystkie inne w królewskiej bibliotece w Berlinie; dosłowne wyciągi podaje Rosen$\mathrm{kranz}^{82}$, tak aby oddać, ile możności, całość poglądów; nadto w Hayma książce o Heglu (Hegel und seine Zeit) z roku 1857, który oparł swe przedstawienie na oryginalnym rękopisie, można rzecz poznaćs3. Sam styl niesłychanie zawiły i ciemny. [Hegel] Nigdy nie był stylista, choć piórem władał, poezje pisał. Goethe powiedział, że brak mu lekkości w przedstawianiu rzeczy. Wilhelm Humboldt powiedział o nim, że 
„język u niego się nie przełamał"84. To dotyczy jego późniejszych dzieł, a cóż dopiero $w$ tym pierwszym zarysie, gdzie sam się bił i łamał ze swymi myślami? „Język matematyki i logiki na przemian się mieszają i luzują się z echami wspaniałymi i poetyckimi" (Haym) ${ }^{85}$. Czasem ciemniejszy niż Böhme, czasem znowu abstrakcyjniejszy aniżeli Arystoteles. A do tego wszystkiego jeszcze ta bezpośredniość, z jaką nas wprowadza w swój świat myśli. Żadne wprowadzenie, nawiązanie do rzeczy znanych, swojskich, żadne orientowanie. Od razu, z pierwszym zdaniem jesteśmy w świecie nowym zupełnie, nieznanym ${ }^{86}$. [s. 34] Żadnej ścieżki wiodącej w ten labirynt. Jedynym kluczem albo znajomość późniejszych pism - tego teraz suponować nie mogę - albo też geneza systemu. To było też powodem, dlaczego o niej tak obszernie mówiłem. Ta geneza, widzieliśmy, miała za punkt wyjścia potrzebę ideału, potrzebę pogodzenia tego, co jest z tym, co wszyscy pragną. Zgoda i związek pomiędzy stroną zewnętrzną i wewnętrzna, pomiędzy częściami i całością pomiędzy formą a treścią miał być przeprowadzony, tak jak to przeprowadziła Grecja klasyczna w poezji i w sztuce, w życiu państwowym i obyczajowym ${ }^{87}$. Przeciwieństwo usunięte tam było pełnią życia, $\mathrm{w}$ pierwotnym chrześcijaństwie miłością $\mathrm{w}$ religii $\mathrm{w}$ ogóle pogodzeniem życia nieskończonego ze skończonym. To pogodzenie przeciwieństwa między tymi biegunami ma być pojęte za pomocą refleksji, za pomocą przenikającej istotę rzeczy myśli. Świat musi być tak pojęty w całości, jakim się przedstawiał w pewnym wycinku w klasycznej Grecji, jakim się przedstawia zawsze w sercu człowieka głęboko religijnego, upatrującego wszystko pod punktem widzenia obejmującym wszystko i godzącym wszystko w miłości Boga ${ }^{88}$. Stworzyć [s. 35] takie pojmowanie rzeczy wymaga ogromnego wysiłku myślenia, a obejmie ta praca cały wszechświat. Wszystko co jest, ma się zlać i pojednać w pięknej i harmonijnej całości. Nie chodzi o to, by tę całość wszechrzeczy analizować, wykryć jej różnice, przeciwieństwa, podziały, lecz podziały znieść, różnice okazać jako jedności, przeciwieństwa pogodzić. Chodzi jednym słowem o to, by wszechświat przedstawić jako piękny, żywy kosmos. Chce wykazać, że w wszechświecie jako całości wszystkie części układają się w całość harmonijna; chce nam ukazać wszechświat jako wielki organizm, w którym nie ma nic martwego, lecz szczegół sam przez się martwy staje się ze względu na całość żywym a służącym jej organem, narzędziem ${ }^{89}$. Chce pokazać, że wszechświat jest totalnością nieskończoną życia, wykazać we wszystkim, co skończone, że jest skończone i że właśnie dlatego wymaga uzupełnienia w kierunku tego, co nieskończone. Ale to zadanie wydaje się niemożebnym do spełnienia. Jaka bowiem może być podstawa takiej budowy myślowej? Z jednej strony świat ma być skończona, doskonałą całością. Z drugiej strony musi w tej całości skończonej znaleźć wyraz jej mnogość i różnorodność, wszystko, co jest cząstka, [s. 36] szczegółem, ułamkiem ${ }^{90}$. A po drugie: gdy mamy wzrok 
zwrócony ku nieskończoności, wznosimy się ponad wszystko, co skończone, ograniczone, niedoskonałe. A z drugiej strony myśląca refleksja nie może się tak, jak uczucie w ekstazie religijnej, wznieść do owej nieskończoności, lecz pozostaje przykuta do jednostkowych, konkretnych objawów; do tego rozgranicza poszczególne twory i formy bytu ${ }^{91}$. Więc chyba podstawa dla takiego pojmowania wszechświata, dla takiego poglądu na świat, jakiego pragnie Hegel, może być tylko ta, że całość jako całość, mimo, że jest w sobie skończona i doskonała, mimo, że jednolita i wyższa ponad wszelkie przeciwieństwa i ograniczenia, przecież w sobie te przeciwieństwa i ograniczenia zawiera. To jest myśl, która już w spekulacji dogmatyków chrześcijańskich znalazła swój wyraz. I rzecz godna uwagi, że Hegel zajmował się właśnie tą stroną spekulacji tych. Mianowicie mam na myśli pojęcie Trójcy. Jedność, a przecież mnogość. Dalej: Bóg staje się człowiekiem, a przecież człowiek ma wznieść się do Boga i stać się takim, jakim jest jego ojciec w niebie. Otóż dogmatem Trójcy Hegel się zajmował w czasie frankfurckim i to właśnie ze strony jego mistyczno-symbolistycznej. [s. 37] (Rosenkranz, 101)92. Współczesny mu filozof teozoficzny Baader, którego wpływ także na Schellinga wyrył swe piętno, nasunął mu myśl napisania rozprawki, którą mamy w rękopisie, pt. Boski trójką̧ ${ }^{93}$. O ile u Baadera trójkąt znanym sposobem symbolizuje Trójcę ${ }^{94}$, o tyle Hegel tym się nie zadowalając, skonstruował trójkąt z trójkątów złożony, który miał właśnie wyrazić totalność życia ${ }^{95}$. To wmyśliwanie się $\mathrm{w}$ symbolikę trójkąta, kto wie, czy nie wywarło wpływu decydującego na całe uczłonkowanie jego systemu. Wszelako jako istota dogmatu Trójcy i wcielenia Syna Bożego przedstawiała się Heglowi, jak to wiemy, miłość, która znowu jest godzeniem przeciwieństw, łagodzeniem ograniczeń wszelkich, jednoczeniem różnic. To pojęcie miłości u Hegla odegrało wielką rolę. Określało tę miłość jako wyrzeczenie się siebie, przeciwstawienie sobie przedmiotu ukochanego, a potem znowu odnalezienie się $\mathrm{w}$ tym ukochanym przedmiocie. I tak pojęta miłość zdawała się wcale odpowiednią na zasadnicze pojęcie filozofii, która miała spełnić powyżej uwydatnione zadanie. A przecież nie wystarczało to Heglowi. Albowiem miłość może tylko odczuć harmonię i zgodność całości mimo różnorodności i przeciwieństwa cząstek. A filozofowi, filozofii musiało o to chodzić, aby pomyśleć, refleksyjnie pojąć tę zgodność w różnorodności. Ani więc symbolizm dogmatyczny Trójcy, ani miłość tego zadania spełnić nie może ${ }^{96}$.

\section{Wykład szósty z 25 listopada 1904 roku}

[s. 38] Istota podstawy wszechbytu nie w miłości tkwić może, bo ona refleksji niedostępna; istota podstawy wszechbytu musi tkwić w czemś, co istotnie pokrewne jest refleksji, myślowemu ujęciu wszechświata. „Zro- 
zumiałym wyrazem dla pojęcia Boga jako wszechżycia byłaby miłość" powiada Hegel; szuka jednak, jak sam powie „wyrazu głębszego"97. Jaki to wyraz, skąd go wziąć? Od razu powiem, wziął go od Fichtego, przeistaczając zasadnicze pojęcie filozofii Fichteańskiej podobnie jak Platon przeistoczył zasadnicze pojęcie filozofii Sokratesowej ${ }^{98}$. Mianowicie Sokrates urobił pojęcie pojęć ogólnych, jako przedmiotowych podstaw wiedzy i jej celu; te pojęcia ogólne potem Platon zhipostazował, nadał im byt przedmiotowy, i w tym m.in. z pewnością wpływ plastyczno-konkretnego sposobu pojmowania, tak charakterystycznego dla Greków ${ }^{99}$. Dla Fichtego celem filozofowania było wykrycie absolutu, tj. ostatecznej podstawy, źródła wszechrzeczy. Znalazł on ten absolut w praczynie ${ }^{100}$. Nie czyn czyjś, lecz czyn absolutny, przez który powstaje absolutna jaźń. Jaźń stawia się sama, das Ich setzt sich selbst ${ }^{101}$. To punkt wyjścia. Drugi [s. 39] krok: Jaźń przeciwstawia sobie niejaźń. Mianowicie według Kanta treść wiedzy z doświadczenia, z otoczenia, z rzeczy samych $\mathrm{w}$ sobie; forma zaś z podmiotu poznającego. U Fichtego także treść z podmiotu. Istotą świadomości, podmiotu, jest działanie, czyn; ale czyn potrzebuje przedmiotu, i dlatego podmiot sobie stwarza przedmiot, otaczający go świat przedmiotowy. Świat jest uzmysłowionym materiałem naszego obowiązku. Ale i trzeci jeszcze krok. Przeciwstawiwszy sobie niejaźń, jaźń poznaje, że niejaźń jest identyczna z jaźnia, o ile jest także jej wytworem. I tak to przeciwieństwo się wyrównuje, godzi, znosi. Teza, antyteza, synteza; dalej ważna tu myśl, że jaźń niejako z siebie wychodzi, a potem znowu do siebie powraca, zupełnie, jak to $\mathrm{w}$ akcie miłości się dzieje, gdzie podmiot kochający zwraca się do drugiego, a w tym drugim znowu siebie, swe uczucia wskutek współczuwania odnajduje ${ }^{102}$. To wszystko były myśli, które niejako się Heglowi nadawały bardzo, harmonizowały z własnymi ${ }^{103}$. Ale przecież wielka jeszcze różnica. Fichte [był] naturą praktyczną, do czynu się zrywającą i dlatego filozofię czynu stworzył; Hegel był umysłem bardziej teoretyczno-kontemplatywnym. [s. 40] A dalej, podobnie jak Platon w porównaniu z Sokratesem, także etykiem, praktykiem, i Hegel w porównaniu z Fichtem miał zwrócony umysł więcej na byt przedmiotowy, poza jaźnią będący. I jak Plato ogólne pojęcie Sokratesa, tak Hegel zhipostazował ów praczyn absolutny ${ }^{104}$. Mianowicie praczyn świadomości, powracający po przeciwstawieniu sobie niejaźni do siebie, przetłumaczył Hegel na działanie istoty wszechświata; co robi u Fichtego podmiot, to u Hegla czyni wszechświat, a raczej jego istota ${ }^{105}$. Na to trzeba było przyjać, że wszechbyt sam jest istotą myśląca, duchowa, który z siebie niejako wychodzi, stwarzając tym sposobem do swego bytu, tezy, byt czegoś innego, antytezę, a potem znowu wyszedłszy $\mathrm{z}$ siebie, do siebie $\mathrm{w}$ syntezie powraca. A zatem absolut, istota wszechbytu jest duchem ${ }^{106}$. Oto oś, około której obraca się filozofia Hegla w tym najwcześniejszym i w każdym późniejszym okresie swego rozwoju. Das Absolute ist Geist - to się powtarza po niezli- 
czone razy w jego wykładach i pismach ${ }^{107}$. Takie twierdzenie pozwalało mu pojąć wszechbyt jako wszechżycie, pozwoliło mu objąć logicznie uczłonkowanym poglądem i jego ideały, i rzeczywistość. Z tej zasadniczej tezy płynie cały podział i zarys jego systemu. [s. 41] Tym samym też w ogólnym zarysie układ systemu dany. Będzie obejmował trzy części. Pierwsza zajmie się duchem absolutnym jako takim, duchem który niejako sam się uświadamia, sam się jako istniejącego stawia i znajduje, wykrywa. Ta część, to Logika i Metafizyka ${ }^{108}$. Druga część zajmie się duchem, o ile on niejako poza siebie wychodzi, uprzedmiotowia siebie, sam się sobie przeciwstawia. To jest Filozofia przyrody, albowiem przyroda jest właśnie uprzedmiotowionym duchem ${ }^{109}$. Trzecia część zajmie się duchem absolutnym, o ile on $\mathrm{w}$ tej przyrodzie, $\mathrm{w}$ tym uprzedmiotowieniu siebie odnajduje i poznaje, analogicznie jak miłość, analogicznie jak jaźń, odnajdująca w przedmiocie myślenia refleksyjnego znowu siebie $^{110}$. Duch więc także od przyrody jako od czegoś innego ku sobie samemu się zwraca. To jest Filozofia ducha ${ }^{111}$. A zarazem to wszystko teza, antyteza, synteza ${ }^{112}$. - Może też teraz zrozumiałem, że ta troistość podziału i pochodu nie jest czymś czysto dowolnym; wiadomo, że liczba trzy odgrywa wielką rolę we wszystkich spekulacjach (Kantowska tablica kategorii: Jakość, Ilość, Modalność [...] Relacja), a tutaj specjalną ma podstawę właśnie $\mathrm{w}$ akcie miłości, i $\mathrm{w}$ akcie myślenia - więc $\mathrm{w}$ dwóch ideach, które Heglowi zawsze były bardzo bliskie.

\section{Wykład siódmy z 2 grudnia 1904 roku}

[s. 42] Ale to tylko ogólny schemat, a w dodatku taki, który może zakrawa na fantastyczny pomysł. Wszechświat pojęty jako duch uprzedmiotowiający się i znowu do siebie powracający ${ }^{113}$. Trzeba nie tylko pomyśleć sobie, że tak jest, lecz trzeba to także wykazać, trzeba dowodów. I to właśnie jest zadaniem całego, szczegółowo przeprowadzonego systemu. Trzeba treść konkretną świata wywieść z absolutnego ducha, trzeba w każdej formie bytu wykazać, że ona właśnie ma te cechy, które jako duch sam się uświadamiający, jako duch przedmiotowy, jako duch powracający do siebie mieć winna; trzeba więc każdą konkretną rzecz, każdy wycinek życia i bytu rzeczywistego zarazem logicznie wywieść z idei całości świata, z zasadniczej myśli systemu, z ducha absolutnego. Logika, abstrakcja, musi ręka w rękę iść z żywą treścią rzeczywistości. Ale to zdaje się niemożliwym. Abstrakcja, logika, i żywa treść rzeczywistego bytu, to przecież przeciwieństwa. Tak, ale właśnie dlatego potrzebny jest jakiś kompromis. Logika musi się naginać, musi swe ostrze stępiać, a rzeczywistość musi ze swej strony do pewnego stopnia przystosować się do Logiki. Całość życia straci przy tym nieco na swej bezpośredniej [s. 43] żywości i plastyczności; ale też Logika straci przy tym 
nieco ze swej nieugiętości, ze swego nieubłaganego ostrego charakteru, stanie się nieco elastyczną. Każdy byt będzie ujęty w pojęciu jakimś, ale też każde pojęcie będzie przyobleczone w szatę bytu, realizowane; każdy szczegół będzie określony jako taki, ale zarazem jako cząstka całości; każda rzecz tym samym będzie zawsze wskazywać na rzecz inna, i jeszcze inna, i tym sposobem przyczyni się to wykazywanie tej natury pojęciowej, dalej ciągle postępującej w każdej rzeczy do tego, że wszystkie rzeczy razem przedstawią się jako żywy proces absolutnego ducha. Stąd te ciągłe i ciągle powtarzające się zwroty w wykładzie Hegla: „realizowanie się pojęcia”, tj. rozszczepianie się pojęcia i stworzenie tą drogą czegoś nowego; "zakres pojęcia zwiera (zamyka) się jako całość”, jeżeli to, co do zakresu należało, znowu do siebie powraca, stawszy się przedtem swym przeciwieństwem ${ }^{114}$. Zwroty te lepiej później zrozumiemy. Teraz jednak one nam pozwalają przynajmniej rozumieć, że w całym systemie Hegla, obok zasady: "absolut jest duchem”, tkwi jeszcze, o ile chodzi o przeprowadzenie systemu, zasada druga: „ów absolut, ów [s. 44] duch przebywa proces dialektyczny"115. To znaczy, że cały wszechświat musi być pojęty jako proces, jako przebieg, jako przejście, jako nieskończona ilość stanów przejściowych, ustawicznie przechodzących $\mathrm{z}$ jednych form $\mathrm{w}$ drugie, $\mathrm{z}$ jednych określeń $\mathrm{w}$ drugie, ale tak, aby te wszystkie określenia, te wszystkie formy razem dały znowu całość bytu, żywego, konkretnego, pojętego jako ustawicznie się 1) uświadamiający, 2) uprzedmiotowiający, 3) do siebie powracający absolut, jako całość zamknięta w sobie i zaokrąglona, obfita w niekończone formy ${ }^{116}$. Oto $t z w$. proces dialektyczny, którego pełne znaczenie także później poznamy dokładniej, gdy ono i u Hegla w późniejszym rozwoju przybierze wyraz pełniejszy; teraz zapamiętajmy sobie tylko, że ten dialektyczny charakter procesu, przebiegu absolutu, a tym samym i systemu, który ten proces, ten przebieg przedstawia, wyłuszcza, zapewnił właśnie systemowi Hegla taki wpływ - między innymi. - Wszelkie kategorie logiki otrzymały tutaj nową jakąś treść, stały się żywymi, przestały być czymś suchym i stężałym. Cały sposób traktowania pojęć i innych kategorii logicznych z gruntu rewolucjonowany. Wszystko płynne, ruchome, powiewne, lotne, żywe. To dialektyka także w złym znaczeniu. [s. 45] Dla przykładu zaraz z początku jego wywodów. Samego początku co prawda, brak. Nie wiadomo, co było punktem wyjścia tego rękopisu ${ }^{117}$. Rozpoczyna się od wywodów, dotyczących pojęcia jakości, Qualität ${ }^{118}$; mianowicie pełny tok analizy pojęcia granicy, kresu. To pojęcie bowiem prowadzi ze sfery pojęcia jakości w sferę pojęcia ilości, Quantität ${ }^{119}$. Dowodzi, że pojęcie kresu, granicy, jest wyrazem tego, czym ,jakość jest wprawdzie, o ile chodzi o jej istotę absolutna, czym jednak być nie powinna, o ile chodzi o jej istotę, iszczącą się w konkretnym bycie" ${ }^{\prime 120}$. Mianowicie jakość jest odnoszeniem przedmiotu do niego samego; jakościowo go określamy, jeżeli określamy go ze względu na niego samego; z chwilą jednak, w któ- 
rej chcemy także w tym określeniu uwzględniać granice przedmiotu, tym samym uwzględniamy także to, co poza tym przedmiotem leży, co więc wskazuje poza przedmiot, na coś innego, drugiego, a tym samym wchodzimy w sferę pojęcia ilości ${ }^{121}$. - Mamy tu próbkę bardzo charakterystyczną i nie trudno zrozumiałą sposobu filozofowania, Heglowskiej dialektyki. Widzimy, jak u Hegla kategorie myślenia, więc abstrakcje logiczne, [s. 46] martwe niejako formy, przybierają ruch i życie. Nie stoją obce obok siebie, rozgraniczone definicjami, lecz przechodzą w siebie, przetwarzają się w siebie, okazują się w swej istocie czymś pokrewnym, tak że abstrakcja i konkretność, ostre linie logiczne i miękkie linie rzeczywistego bytu w jedną spływają się całość. - Nie będę wdawał się w szczegóły tego pierwszego zarysu; widzimy, jakim był; zobaczmy, że zasadnicze myśli i metody wszystkie przeszły w późniejszy, ostateczny kształt systemu ${ }^{122}$. Dalszy rozwój tego systemu dokonał się pod wpływem tych wszystkich podniet życiowych i umysłowych, i filozoficznych, które działały na Hegla w Jenie. Tam dojrzało wszystko, co dotąd było jeszcze nie dojrzało.

Wiemy, że miał zamiar udać się nie wprost, lecz zrazu do Bamberga. List do Schellinga z 2 listopada 1800 roku $^{123}$. Otóż zdaje się, że Schelling w liście, którego już nie posiadamy, skłonił go do zmiany zamiaru i namówił go, by się wprost do Jeny udał. I tak też uczynił Hegel, przybywając do Jeny w styczniu roku 1801. Rzuca się, jak się sam wyraża „in den litterarischen Haus von Jena", w wir literacki w Jenie ${ }^{124}$.

[s. 47] ([Wykład nadal prowadzony według] Hayma, VI. Vor. $\left.{ }^{125}\right]$

Jena, małe miasteczko uniwersyteckie, wówczas centrum umysłowego życia w Niemczech. Schiller. Wilhelm Humboldt. Czasami bawił tu Goethe, Reinhold, tu Fichte, Schlegel, Novalis, Tieck, tu na koniec Schelling. Heglowi nie był ten duch całkiem obcy. Goethego i Schillera czytał, ich ideałami klasycznymi się upajał ${ }^{126}$. Fichtego Wissenschaftslehre znał i był pod jej wpływem; Schellinga dzieła czytał w czasie frankfurckim. Ale rozwijał siebie i swe poglądy przecież w sposób samodzielny, spokojny. Przybywszy do Jeny, wszedł w świat przeto nowy, a wątpliwe było, czy w tym nowym świecie dla niego i jego systemu, mimo iż ten system wyrósł na Fichtem po części, będzie miejsce, zwłaszcza, że już samego Fichtego nie było tam. Ale i Schelling był wyszedł od Fichtego, i to w znacznie wyższej mierze od Hegla; więc najlepszym wprowadzeniem $w$ ten nowy świat dla Hegla uwydatnienie swego tym sposobem pośredniego związku z Schellingiem. Istotnie też dokonały się pewne modyfikacje $w$ poglądach Hegla pod wpływem ponownego osobistego i naukowego zetknięcia z Schellingiem. To jest nowy okres w tworzeniu się systemu Heglowskiego, i aby go zrozumieć, rzućmy okiem na system [s. 48] Schellinga ówczesny, na stosunek jego do całego poprzedniego ruchu filozoficznego w Niemczech, o ile ten ruch nam właśnie dla zrozumienia sprawy potrzebny ${ }^{127}$. 
W tym celu zauważmy, jaka była zasadnicza myśl Kantowskiej filozofii, nie tylko dotyczy jego teorii poznania. Myślą tą krytycyzm, pogodzenie dogmatyzmu i sceptycyzmu na gruncie praktycznym ${ }^{128}$. Rozum nie tylko teoretyczny, lecz także praktyczny, sumienie. A ten praktyczny pierwszeństwo przed teoretycznym. Ten rozum praktyczny jest sobie tak samo prawodawca, jak rozum teoretyczny prawodawcą przyrody. Rozum praktyczny ma w sobie prawo kategorycznego imperatywu, a ten kategoryczny imperatyw łączy się z postulatami praktycznymi istnienia Boga, wolnej woli, nieśmiertelności duszy. Tak więc pogląd na świat opiera się na praktycznych czynnikach, na działaniu ludzkim. Cały świat pod znakiem moralizmu. Tę myśl doprowadził Fichte do ostateczności ${ }^{129}$. Rozum nie tylko daje prawa przyrodzie i sobie, ale sam stwarza przyrodę, i ten czyn twórczy jaźni jest początkiem wszystkiego, nawet jej samej. Kompletny despotyzm jaźni, potęga jej u szczytu. [s. 49] Cały świat, cały proces dziejowy, to tylko ustawicznie działanie jaźni, przeciwstawiającej sobie niejaźń i znowu do siebie powracającej. Ale ten świat, który jaźń sobie przedstawia, nie odzwierciedla tej jaźni zupełności i dokładnie jest tylko słabym jej odbłyskiem. Nie jest tym, czym być powinien i czym jaźń w nim być powinna. Więc ma się ten świat stać innym, ma spełnić zadanie, zakreślone mu prawem moralnym. Czysta więc forma naszej jaźni iścić się może tylko w nieskończonym procesie dziejowym, przekształcającym świat zmysłowy, przyrodę, niejaźń w świat moralny, jako odblask i wyraz prawdziwej istoty jaźni. Cały więc świat zmysłowy, cała przyroda tylko fazą przejściowa, tylko czymś niedoskonałym, a właściwym panem, właściwą pania, jedynym bytem rzeczywistym jaźń ${ }^{130}$.

\section{Wykład ósmy z 9 grudnia 1904 roku}

[s. 50] Pogląd ten, siłą swych myśli i siłą przekonania, z którym Fichte go głosił, olśniewał niejednego, olśnił także Schellinga ${ }^{131}$. Zrazu uważał się też za kontynuatora albo raczej za propagatora i apostoła tego poglądu. Uzasadniał, wyjaśniał, jak Fichtego pogląd musiał się wyłonić z Kantowskiego. Ale nie pozostał na tym stanowisku Schelling, a zepchnęły go z niego prądy, które wówczas także silnie się zaznaczały i także pośrednio od Kanta swój początek wiodły. Kant uznawał zjawiskową rzeczywistość empirycznej przyrody, a jej byt opierał na rzeczach samych w sobie, na bycie przedmiotowym z zupełności. W jego oczach przyroda nie była tak strasznie czymś niskim w porównaniu z umysłem, co więcej, ten umysł uszlachetniał ją niejako, ujmując ją w prawa swoje własne. I to taki pogląd zgodny z nowo rozbudzonym z końcem wieku XVIII ruchem na polu nauk przyrodniczych. W ciągłym związku z filozofią zrazu nauki przyrodnicze rozpoczynały swój pochód triumfalny. Che- 
mia i fizjologia, geologia i zoologia. Dzieła, jak np. Philosophie zoologique Cuviera 1832 albo Zoologie philosophique Lamarcka 1829, są tutaj bardzo znamiennym symptomem ${ }^{132}$. Otóż przyroda to coś, co także Schellinga żywo interesowało. Dlatego też szukał i znalazł wyjście, aby stanowisko Fichtego pogodzić z bardziej szanującym stanowiskiem wobec przyrody. Powiedział sobie więc: tak, Fichte ma rację, umysł ludzki tworzy przyrodę i daje jej prawa; wszechświat tylko projekcją [s. 51] naszej jaź$\mathrm{ni}^{133}$. Ale właśnie dlatego wolno nam, a nawet trzeba tę projekcję jak najdokładniej poznać. Trzeba świat i przyrodę studiować. Przystępuje do dzieła, przedstawia szczegółowo przyrodę jako rodzaj ilustracji żywej i zmysłowej naszej i absolutnej jaźni. Obok filozofii jaźni absolutnej stawia filozofię przyrody, tego odzwierciedlenia jaźni. I ciągle uważa się za wykonawcę myśli Fichteańskich, a przecież powoli, nieznacznie stanowisko wskutek tego swe przesuwa i odsuwa od Fichtego. Zapomina powoli o jaźni jako źródle przyrody i przyrodę samą w sobie, jako równouprawniony obok jaźni byt rozważa. Zapomina, że przyroda „słabym odblaskiem naszego własnego bytu, mającego się rozwijać przez całą wieczność"134. Filozofia przyrody obok filozofii transcendentalnej jako równouprawniona gałąź; transcendentalna podporządkowuje świat obiektywny, realny, podmiotowemu, oddalonemu; przyrody filozofia odwrotnie. Obie gałęzie nawzajem się uzupełniają ${ }^{135}$.

Na tym stanowisku był Schelling, gdy nowe prądy nowy zwrot w nim wywołały. Te nowe prądy, to romantyzm. Wiemy, że klasycyzm Schillera i Goethego w krainie ideału starał się pogodzić wszelkie przeciwieństwa rzeczywistości i marzeń. [s. 52] Ale te ideały były dalekie; poznawszy je jednak, starano się ściągnąć je niejako na ziemię; sztuka, która je nam ukazała, ma się stać przewodniczką w życiu, może $w$ ten sposób ideały, stworzone w wyobraźni, przyobleką szatę rzeczywistości. I oto wyłoniła się z epoki klasycznej poezji niemieckiej rychło bardzo romantyka. Wyobraźnia i tylko wyobraźnia, ale nie tylko w poezji, lecz także w życiü ${ }^{136}$.

Czym dotąd rozum i nauka, tym stać się miała wyobraźnia i sztuka. Więc na najwyższym stopniu piedestału stanął artysta, twórczy geniusz. Entuzjazm ten w związku z Fichteańską filozofią tworzy teorię genialnego osobnika, rozwiniętą przez Schlegla. Nie jaźń jako istota moralna, jak to Kant, a po nim Fichte chcieli, lecz jaźń jako istota artystyczna i genialno-twórcza, oto pani świata i życia. Oto duch, który w pewnej fazie opanował Schleiermachera, oto duch, który całkowicie opanował Schellinga ${ }^{137}$.

To, co nam daje wyobraźnia wobec dzieła sztuki, zarówno gdy je tworzymy, jak gdy się nim zachwycamy, to samo ma się stać naszym udziałem także wobec świata. Więc nie drogą [s. 53] rozumowej analizy świat zrozumiemy, lecz obejmiemy go [drogą żywego odczuwania, drogą konkretnego ujęcia, spoglądając nań okiem artysty, a nie anato- 
ma. Oto myśl zasadnicza, wyrażona u końca dzieła z roku 1800 z marca, w Systemie transcendentalnego idealizmu ${ }^{138}$. W tej książce: niezgodność między ideałem jaźni a jej odblaskiem w świecie, w przyrodzie, może być wyrównaną przez stanowisko estetyczne względem świata. A jeżeli mamy zająć wobec świata stanowisko estetyczne, wtedy sztuka staje się nam kluczem dla jego pojmowania; albowiem sztuka właśnie jednoczy twórczą myśl artysty z przedmiotowym jej realizowaniem ${ }^{139}$.

Więc sztuka jest „wiecznym organon i dokumentem filozofii", ,"sztuka jest wzorem nauki"140. Cała więc filozofia wraz ze wszystkimi naukami musi na nowo „powrócić do ogólnego morza poezji, z którego wypłynęła"141. Sztuka musi się stać ogólnym schematem dla sposobu ujęcia wszechświata, dla poglądu na świat. - Myśl tę przeprowadza w dalszym ciągu Schelling śmiało i konsekwentnie. Czyni skok z poziomu nauki w bezdenność poezji. Filozofia stała się poezją. Stanowisko estetyczne przestało być jednym z licznych, uzupełniających się stanowisk, stało się stanowiskiem jedynym, wyłącznym. [s. 54] Sztuka stała się aprioryczną zasadą konstrukcji świata. Jak w dziele sztuki podmiotowa twórczość i przedmiotowy byt $\mathrm{w}$ jedno się zlewają stają się czymś identycznym, tak też strona podmiotowa, idealna, umysłowa i przedmiotowa, realna, zmysłowa świata staje się identyczną ${ }^{142}$.

I oto jesteśmy $\mathrm{w}$ pełni filozofii identyczności ${ }^{143}$. Powstała ona pod wpływem właśnie wspomnianych prądów, w połączeniu z jeszcze jednym, w połączeniu z wpływem Spinozy, którego już dawniej Schelling wielce był umiłował. Więc identyczność, oto teraz formułka zbawcza. Przeciwieństwo i zarazem równoległość filozofii transcendentalnej i filozofii przyrody cudownie się sprowadza do pierwotnej identyczności wszystkiego. Identyczność początkiem, najwyższym prawem, końcem wszystkiego. Wszystko, co jest, w gruncie rzeczy jest identycznym. Nie jaźń, nie rozum, nie duch początkiem siebie i przyrody, lecz identyczność ducha i przyrody początkiem ducha i przyrody. Jak artysta wszędzie widzi harmonię i identyczność pierwiastków twórczych natury ludzkiej z dziełem tworzonym, tak też filozof identyczność w wszechświecie widzi. Filozofia, to jak twórczość artysty, darem geniusza, specjalnego uzdolnienia. I to nam tłumaczy i treść i formę filozofii Schellinga ${ }^{144}$. [s. 55] [Haym, VII ${ }^{145}$ ]

Tak więc Schelling był dokonał bardzo silnego zwrotu w swych poglądach w czasie bardzo krótkim. System transcendentalnego idealizmu w marcu 1800 roku, a już z początkiem roku 1801 Wykład mego systemu filozoficznego (Darstellung meines Systems) ${ }^{146}$.

W pierwszym dziele jeszcze Fichte, w drugim filozofia identyczności, Spinoza. I może nie bez słuszności jest uwaga Hayma, że właśnie przybycie i wpływ Hegla, który przecież właśnie z początkiem, w styczniu 1801 roku do Jeny przybył, dokonał w Schellingu tego przewrotu. Albowiem owa Darstellung widocznie z najwyższym pośpiechem pisa- 
na, całkiem nie przetrawiona, nie wykończona w szczegółach, pobieżny szkic. Może być, że zetknięcie się osobiste z Heglem spowodowało szybkie pisanie i publikowanie poglądów, które już dojrzewały w Schellingu i częściowo znalazły wyraz u samego końca Systemu transcendentalnego idealizmu ${ }^{147}$. - Jakiż więc był stosunek obu filozofów pod względem ich poglądów, a także ich stosunek osobisty po przybyciu Hegla do Jeny?

\section{Wykład dziewiąty z 20 stycznia 1905 roku}

Niezawodnie mamy tu rysy pokrewne i rysy różne ${ }^{148}$. I. Pokrewieństwo: a) obaj dogmatykami w przeciwieństwie do krytycyzmu Kanta, b) obaj ze [Tu następuje pisana odręcznie notka Kazimierza Twardowskiego zapisana na stronie nienumerowanej. Jest to streszczenie części wykładu Hayma: Rekapitulacja: 1) Lata gimnazjalne; 2) Lata uniwersyteckie (Hölderlin, świat klasyczny, rewolucja francuska); 3) Guwernerka w Bernie szwajcarskim 1793-1796, teologia, historia, lekt. filozofii; Fichte i Hölderlin, obok Kanta, Racjonalizm w chrześcijaństwie na tle świata klasycznego; 4) Guwernerka w Frankfurcie początek 1797- początek 1801, Polityka a filozofia System własny. Podstawowe myśli: "Jaźń Fichtego" uprzedmiotowiona. Rozum a duch. świadomość = absolut, zarazem - praktycznego rozumu oraz rozum teoretyczny, Teza : antyteza : synteza; Log. i metodol.: Fil. przyrody: fil. ducha: Metoda dialektyczna; 5) Początek 1801 Jena - Schelling. Ten zrazu całkiem Fichte. Potem przyroda jako równoznaczna obok jaźni. Romantyzm - pierwiastek konstrukcji poetyckiej. Wyobraźnia. Spinoza filozofia identyczności] [s. 56] stanowiska autonomicznego rozumu, teoretycznego i praktycznego, zeszli [się] na stanowisku, w którym całość wszechbytu pierwsze zajmowała miejsce, c) obaj wskutek tego usunęli dualizm, do którego prowadził Kant zjawiskami i rzeczą samą w sobie, rozumem teoretycznym i praktycznym, a który jeszcze u Fichtego mimo sprowadzenia wszystkiego do absolutnej jaźni pod względem moralnym istnieje, i w jego miejsce postawili monizm, d) obaj zamiast dedukcii koncepcję dają e) dla obu w przeciwieństwie do Kanta i Fichtego przyroda, świat zewnętrzny przedmiotem równorzędnym badania, f) obaj daja jednym słowem system zaokrąglony, czego ani Kant, ani Fichte nie uczynili, g) a u obu system ten ma pewien wspólny rys charakterystyczny: wszechbyt, odbity w systemie, jest jednolita harmonijną całością, niemalże dziełem sztuki. - To cały szereg rysów wspólnych. - II. Ale są i ważne różnice: a) Inną drogą każdy doszedł do własnego systemu. Schelling zrazu pod wpływem Fichtego całkowitym; stopniowo się emancypuje, ale stara się utrzymać zgodność z Fichtem. Przyroda go wabiła, ale i jaźń [s. 57] go ciągnęła ku sobie. Waha się, aż na koniec skokiem śmiałym zrywa z Fichtem, przy czym jednak jeszcze w przedmowie do Darstellung powiada, iż nie jest niemożebną rzecza, 
by Fichte jeszcze kiedyś wspólną z nim wyznawał filozofię. - Inaczej u Hegla, gdzie nie ma takich wahań i stopniowych zmian stanowiska. Od razu ma w zarysie pogląd swój gotów, a raczej od razu w pewnym kierunku pogląd ten nie tworzy. Wprost ku celowi zmierza, a cel ten nie zmienia się kolejno. Schelling porusza się w zakolach, a Hegel po prostu w górę idzie; b) Zwrot w filozofii Schellinga przez estetykę romantyzmu spowodowany. U Hegla natomiast klasycyzm. Schelling znał go tylko z drugiej niejako ręki; Hegel czerpał u źródła. Schelling pod względem estetycznym, a ten wzgląd decydujący dla jego systemu, był potomkiem klasycyzmu niemieckiego, gdy tymczasem Hegel stanął obok tego klasycyzmu i jego zasadnicze idee filozoficzne wyrażał, gdy Schiller i Goethe czynili to w poezji; c) Wskutek swej linii rozwojowej Schelling w późniejszych fazach, przebywszy fazę Fichteańska, zupełnie ją niejako złożył ad acta. Była to dla niego sprawa raz [s. 58] na zawsze załatwiona. Kant i Fichte überwundener Standpunkt. Teraz Spinoza mu wzorem i kierownikiem. Inaczej Hegel. U niego poglądy Kanta, Fichtego, Shellinga nawet wetkane w system, wchodzą niejako w skład. Cały materiał myślowy Kanta i Fichtego wchodzi w konstrukcję systemu Hegla, jak to jeszcze zobaczymy; d) Dalej. Obaj wprawdzie jako całość harmonijną wszechświat pragną przedstawić. Ale u Schellinga to stanowisko jest subiektywne bardziej, stanowisko artysty, tworzącego i używającego dzieło sztuki; u Hegla natomiast chodzi o zanalizowanie warunków i cech, dzięki którym to dzieło jest piękne, jednolite, zaokrąglone. Schelling artysta wobec dzieła, impulsywnie zachwycający się nim i opowiadający nam o tym; Hegel znawca, analizujący to dzieło.

Tak by można mniej więcej przedstawić stosunek obu systemów. W owej chwili. Więc różnice ważne. A jedna zwłaszcza Heglowi musiała się rzucić $\mathrm{w}$ oczy. Schelling nie był gotów z tym nowym swym systemem; nie był on wykończony, a Hegel już [s. 59] miał w głowie i na papierze system, który był obmyślany w szczegółach. Ale zasadnicze tendencje systemów pokrewne. Monizm, objęcie całości, punkt widzenia estetycznej harmonii. I to musiało nasunąć Heglowi myśl, która się właśnie w jego postępowaniu objawiła: Myśl, użyczenia Schellingowskiemu systemowi ze swego, czego mu brakło: wykończenia w szczegółach, sformułowania rzeczy zaznaczonych, ścisłego uświadomienia całej treści i konsekwencji tych poglądów. Stał się zrazu interpretatorem systemu Schellingowskiego. To jemu samemu było potrzebne. Wszak o Heglu nikt nic nie wiedział, a Schelling gwiazdą jasną był; wszak między nim a Schellingiem pokrewieństwo tym większe, im bardziej ich rozpatrywano w stosunku do Kanta i Fichtego. Ta nowa filozofia niekantowska, niefichteańska musiała sobie zdobyć grunt, a i Schelling i Hegel mieli taką filozofię; więc zdobywając grunt dla Schellinga i dla siebie Hegel grunt zdobywał. O ile uświadamiał sobie różnice między sobą a Schellingiem, nie wiemy. Dość, że zrazu zidentyfikował zupełnie swo- 
ją filozofię z Schellingiańską. Oto pierwsze stanowisko, które zajął Hegel w Jenie. ([Odwołanie Twardowskiego do wykładu] Hayma, 157 ${ }^{149}$ ).

[s. 60] Stanowisko to i na zewnątrz było widoczne. Mawiano, że Schelling zapisał sobie ze swej ojczyzny (Wirtembergii) towarzysza broni; Hegel przeciw temu protestował; ale przyznać trzeba, że sam dał powód do takiego pojmowania swego stosunku do Schellinga ${ }^{150}$. Wszak stanowisko to narzuca się niemal w pierwszej książce, którą wydał Hegel w Jenie, w połowie roku 1801 pt. Differenz des Fichteschen und Schellingschen System der Philosophie ${ }^{151}$. W książce tej Hegel ani jednej słówkiem nie zdradza, że posiada swój własny system filozofii. Przeciwnie, wygłasza zdanie, że filozofia Schellinga jest jedyną prawdziwą i słuszną filozofia, że ona jedyna wzniosła się nad wadliwy punkt widzenia, reprezentowany przez Fichtego, do trafnego sposobu patrzenia na rzeczy i spoglądania na świat. Ani jednej uwagi krytycznej w odniesieniu do Schellinga. Staje z większą stanowczością na stanowisku Schellinga, aniżeli sam Schelling. Schelling bowiem, jak widzieliśmy, nie uważał za rzecz wykluczona, że jeszcze na polu filozofii zejdzie się z Fichtem; natomiast Hegel uważa to za rzecz wykluczona, i całkiem jaskrawo podkreśla zasadnicze różnice dzielące ziejącą przepaścią Schellinga [s. 61] od Fichtego. Słowami Schellinga uzasadnia jego poglądy; dowodzi, że jedynym trafnym poglądem jest pogląd absolutnej identyczności podmiotu i przedmiotu; trzeba zarówno podmiot, czyli rozum, jak przedmiot, czyli przyrodę uznać za zjednoczenie, identyczność podmiotu i przedmiotu. Tak rozum i przyroda będą działami osobnymi wiedzy, a przecież te działy, tj. filozofia transcendentalna, czyli ducha, i filozofia przyrody dzięki identyczności tego, o czym traktują nie wejdą ze sobą w sprzeczność. Różnica między działami tylko ta, że w jednym podmiotowa, idealna, duchowa, w drugim przedmiotowa, realna, przyroda dominująca mniej lub więcej. - Otóż to całkiem Schelling, a nadto wyraźniej, dobitniej, jaśniej sformułowany aniżeli sam Schelling, którymi może dopiero ta książka Hegla w zupełności uwydatniła jego własne stanowisko. Faktem jest, że dopiero odtąd Schelling sam tak jasno i stanowczo formułuje swe poglądy; formalną stronę wykończenia swego poglądu zawdzięcza w znacznej mierze niewątpliwie Heglowi ${ }^{152}$.

\section{Wykład dziesiąty z 27 stycznia 1905 roku}

[s. 62] Nic dziwnego, że wobec takiego stanowiska Hegla działalność obu w Jenie zrazu zupełnie się zlała w jedno. Utworzyli spółkę filozoficzno-literacką do której wniósł Schelling stanowisko, rozgłos, firmę, a Hegel swą wytrawność, swą niezmordowaną pracowitość. Filozofia absolutnego idealizmu, zwana tak dla odróżnienia od Fichteańskiej filozofii podmiotowego idealizmu, w ustach Schellinga i Hegla nazywa się 
krótko „nasza” filozofiaa ${ }^{153}$. Ta wspólność objawiła się zaraz też w działalności akademickiej Hegla. Hegel bowiem przyjechał do Jeny, by się habilitować ${ }^{154}$. Wprawdzie nie brakło tam docentów filozofii. Fichtego, co prawda nie było; przybywszy do Jeny w 1794 roku jako następca Reinholda, pozostawał tam do roku 1799, w którym z powodu tzw. sporu o ateizm (Atheisemusstreit) musiał uniwersytet opuścić. Ale mamy na przykład daty z lat 1803/4. W letnim półroczu 1803 wykładali w uniwersytecie 52 profesorowie i docenci. $Z$ nich filozofię 12; mianowicie 3 prof. zw., 2 nadz. i 7 doc. prywatnych. Na wydziale filozoficznym było w ogóle 9 doc. pr., a z nich 7 filozofii. W zimie 1803/4 48 sił nauczycielskich w uniwersytecie; z tego 12 wykładało filozofię. Więc czwarta część. W lecie 1804 na wydziale filozoficznym było 7 doc. pr. [s. 63], a z tego 6 wykładało filozofię. Ogółem sił nauczycielskich było 42, z tego filozofów 9. Do nich należał Hegel. Obok niego np. Fries, Krause, i inni mniej znani ${ }^{155}$. Praca habilitacyjna Hegla dla niego i jego stanowiska filozoficznego bardzo charakterystyczna. Tytuł: Dissertatio philosophica de orbitis planetarum. Pro licentia docendi, Ienae $1801^{156}$. Chciał w pracy tej apriorycznie dedukować prawa Keplerowskie ruchu planet. Między innymi dowodzi tam, że między Marsem a Jowiszem nie może być planety; dowodzi na podstawie wziętych z Timeusza [Timajosa] Platońskiego spekulacji liczbowych; tymczasem już wtedy astronomowie wiedzieli, że tam jest planeta, mianowicie Cerera (Ceres)! ${ }^{157}$ - Otóż na podstawie tej pracy habilitował się Hegel dnia 27 sierpnia 1801 roku, więc w dniu urodzin, kończąc lat $31^{158}$. Zaraz na następne półrocze zimowe ogłosił w programie wykładów: Ge. Wilh. Frid. Hegel privatim Logicam et metaphysicam docebit hora VI. ad VII gratis introductionem in philosophiam tractabit et disputatorium philosophicum communiter cum Exellentessimo Schellingio diriget ${ }^{159}$. W 1805 roku był już prof. nadzw. bezpłatnym; w 1806 jego płaca wynosiła 100 talarów (list Goethego). - Więc wspólne seminarium filozoficzne! A innym widomym znakiem tej spółki filozoficznej było wspólnie przez nich wydawane i redagowane [s. 64] czasopismo pt. „Kritisches Journal der Philosophie". Wyszły tylko dwa tomy w roku 1802; to w ogóle wówczas bardzo przyjęte ${ }^{160}$. Fichte z Niethammerem wydawali swego czasu „Philosophisches Journal”, 1795-1797 ${ }^{161}$; sam Schelling wydawał już przedtem „Zeitschrift für speculative Physik" w Jenie, 1800-1801, dwa tomy, a potem „Neue Zeitschrift für speculative Physik” (Tübingen), tylko jeden tom, 1802. Większość artykułów tam Hegel umieszczał, tylko czwartą część Schelling. Ale kto, co pisał, nie wiedziano; bez podpisu i w jednym duchu. Podobnie jak Schiller i Goethe Xenia, a podobieństwo także w tym, że ostrze krytyczne i polemiczne, wraz z satyrą bardzo silnie były reprezentowane. Zwłaszcza przeciw Reinholdowi zwracali się. Wiele kwestii, wspólnie przedyskutowanych przez obu redaktorów, potem $\mathrm{w}$ formie dialogów ukazywały się w tym czasopiśmie. Do dziś dnia nie można o wszystkich artykułach decydować, czyjego są pióra. - Tak 
więc wspólna praca, wspólna działalność; blaskiem i honorami Schelling pierwsze zajmował miejsce, ale powoli Hegel kładł podwaliny pod swe późniejsze stanowisko, zaćmiewające Schellinga ${ }^{162}$.

[s. 65] ([Kontynuacja wykładu za] Haymem, VIII ${ }^{163}$ ).

Tymczasem jednak pod jednym względem odbił się wpływ Schellinga na Heglu w sposób całkiem niewątpliwy: pod względem formy. Dowodem na to dalsza jego praca filozoficzna nad rozpoczętym we Frankfurcie systemem. Tam były powstały: Logika oraz metafizyka i fizyka. Teraz dodał trzecią część System moralności (System der Sittlichkeit $)^{164}$ - (mylne u nas często tłumaczenie przez obyczajność zam[iast] moralność). Obejmuje 22 arkusze, zewnętrzną pobudką do opracowania tego systemu moralności było przygotowanie się do zapowiedzianych na półrocze letnie 1802 i zimowe 1802/3 wykładów pt. jus naturae (w lecie jus naturae, civitatis et gentium ${ }^{165}$, w zimie tylko jus naturae ${ }^{166}$ ). Były to dziedziny filozofii, dla których Schelling nie okazywał zbytniego zainteresowania. Jemu przyroda bożyszczem była, gdy tymczasem właśnie Hegel od czasów nauk swych najbardziej zajmował się kwestiami historyczno-politycznymi. Wiemy już, że te kwestie go w Frankfurcie zajmowały ze strony krytycznej, że napisał tam w 1798 o wewnętrznych stosunkach Wirtembergii, że tam też dojrzewały myśli, spisane potem już w Jenie o [s. 66] Niemczech jako o państwie i o ustroju Niemiec ${ }^{167}$. Otóż uzupełnieniem niejako, a z drugiej strony filozoficznem zaspokojeniem tych politycznych interesów jego umysłu był System der Sittlichkeit, teraz powstały. Ten system moralności był koniecznym zakończeniem jego systemu filozofii; wszak właśnie po tezie absolutnego ducha i antytezie ducha uprzedmiotowionego w przyrodzie musiała nastąpić synteza ducha powracającego do absolutu ${ }^{168}$. Otóż ten system moralności w zupełności opiera się na tym samym gruncie, co reszta filozofii Heglowskiej: na klasycyzmie. Nie ma śladu owego romantycznego kultu genialnej jednostki, indywidualizmu, kultu, cechującego koła romantyczne, do których całą duszą należał Schelling, kultu, któremu byłby był dał Schelling wyraz, gdyby on był wówczas pisał system moralności. Natomiast jest ten cały system moralności Heglowskiej pod względem treści obrazem życia klasycznego greckiego w kierunku państwowym, społecznym, artystycznym i religijnym. Ta forma życia jest tu u Hegla podniesiona do znaczenia absolutnej wartości i miary. To zupełnie w zgodzie z dotychczasowym trybem myślenia. [s. 67] Wiemy, jak pojmował chrześcijaństwo z punktu widzenia tego klasycyzmu; wiemy, jak usiłował pojmować wszechświat jako harmonię, jako kosmos, gdzie każdy szczegól, każdy byt konkretny nabiera pełnego znaczenia i uprawnienia ze względu na całość $\mathrm{i}$ jak ta całość jest $\mathrm{w}$ duchu panteistycznym eleatów wyrazem absolutu jednego. Teraz ten absolut ze sfery pojęć zstępuje w sferę konkretnej rzeczywistości. Dotąd trzeba go było odnajdywać pod powłoką myślenia i przyrody; obecnie staje przed nami kon- 
kretnie i żywy. System moralności, to jest właściwa teraz filozofia ducha, synteza. $\mathrm{W}$ późniejszym systemie ta filozofia ducha znacznie bogatsza; wyprzedza ją nauka o duchu subiektywnym, czyli psychologia i antropologia; następuje po systemie moralności nauka o duchu objawiającym się w sztuce, religii, filozofii; teraz zaś to wszystko ściąga się i wyraża wyłącznie w systemie moralności. Teraz dla niego absolut realizował się całkowicie w życiu moralnym; duch moralny był teraz dla niego duchem absolutnym w absolucie, der Absolut - absolute Geist ${ }^{169}$. Obiektywna moralność, objawiająca się w życiu państwowym [s. 68] jest więc najwyższą formą realizowania się ducha absolutnego. Nic wyższego pomyśleć się nie da. Dlatego zowie się tym, co „boskie”, das Göttliche. W sferze moralnej bowiem jednostka istnieje sposobem wiecznym; w sferze moralnej nie jego indywidualność się objawia i działa, lecz tkwiący w nim duch ogólny, absolutny. Tutaj zupełnie iści się pogląd filozoficzny na rzeczy, według którego wszystko jest w Bogu i żaden byt szczegółowy nie jest. Religia danego narodu nie jest niczym innym, jak uświadomieniem sobie tej boskości własnej, objawiającej się w życiu moralnym. Zjednoczenie jednostki z całością w państwie jest boskością narodu, gdy naród wyobraża sobie to zjednoczenie, wytwarzające jego boskość, w formie konkretnej, jednostkowej, dochodzi do pojęcia Boga, którego czci. Moralność zaś przybiera w narodzie formę najwyższą wtedy, gdy owo wyobrażenie boskości konkretne wciela w rzeczywistość swego życia moralnego. „Im bardziej naród jednoczy się z sobą, z natura, z moralnością, tym bardziej wchłania w siebie boskość i tym bardziej usuwa od siebie religię ${ }^{\prime 170}$. Oto w myśl Kantowskiej zasady, proklamującej [s. 69] pierwszeństwo praktycznego rozumu, sumienie, przed pojęciami religijnymi i wyprowadzającej wiarę w Boga z poczucia etycznego. Tylko, że u Hegla pierwszeństwo to otrzymuje nie rozum praktyczny, lecz jego objawy w życiu moralno-państwowym ${ }^{171}$.

\section{Wykład jedenasty z 3 lutego 1905 roku}

W swych wykładach, które na podstawie tego systemu moralności wygłosił [Hegel], i do których jeszcze wygotował inne rękopisy, mamy zastosowanie tych oderwanych twierdzeń do rozwoju historycznego ${ }^{172}$. Życie moralne, w którym naród czuje boskość w sobie, a która wyraża się $\mathrm{w}$ jego religii, jest zarazem miarą tej boskości. Było ono wysoce rozwinięte w starożytnej Grecji. Upadło z nią razem. Miejsce tej moralności, jednoczącej w sobie ducha i przyrodę, zajęła religia sama jako surogat ${ }^{173}$. Powstało chrześcijaństwo. Wiara w boskość moralnego życia skoncentrowała się tutaj w wierze w boskość jednostkową. Ale duch ludzki dążył do odbudowania wiary w boskość własną urzeczywistniającej się $\mathrm{w}$ jego życiu moralnym. To prowadzi do ruchu reformatorskiego, do 
protestantyzmu. Ale pełna świadomość tej boskości, danej ludzkości przez moralność, [s. 70] dopiero w filozofii występuje. Ale nowa religia dopiero wtedy powstanie, gdy zrealizuje się najwyższa idea tej filozofii, gdy „wolny naród będzie znowu istniał i rozum odnajdzie znowu swą rzeczywistość jako ducha moralnego, który będzie na tyle śmiałym, by na własnym gruncie i ze swego własnego majestatu utworzyć sobie swą własną postać religii"174.

Tak samo, jak w tej konstrukcji idealnej jednostka roztapia się w życiu moralnym ogółu, w którym się system moralności urzeczywistnia, tak też i pod każdym innym względem $w$ tym państwowym życiu jednostka pod ogół się podprowadza, całkiem w myśl starożytnych poglądów Platona i Arystotelesa, którzy dzielność i cnotę uważali za możliwe tylko w państwie i tylko dla państwa kazali jednostce istnieć. Państwo i ojczyzna zastępują niejako u Hegla kategoryczny imperatyw, w czym wolno nam się dopatrzeć prócz wpływów Platońskich i Arystotelesowych także wpływów Fichteańskich. Hegel nawet szkicuje państwo idealne, bardzo podobne do idealnej rzeczypospolitej Platona. Rządy i ustawodawstwo mają spoczywać [s. 71] w rękach starszyzny i kapłanów, czytamy u Hegla, a cała ludzkość podzielona na trzy stany itd. ${ }^{175}$.

Ale jeżeli wskazaliśmy na wpływy prowadzące do takiego podporządkowania jednostki pod ogół w państwie, godzi się pamiętać, że w tych wpływach jeszcze coś innego się mieści. Ta apoteoza ogółu, a zarazem pewne lekceważenie bytu jednostkowego $\mathrm{w}$ tym stopniu każe się domyśleć wpływów Spinozistyczno-Schellingowskich, gdyż właśnie Schelling był niewyczerpany w hymnach na cześć i wspaniałość absolutu. Nadto cały szereg wyrazów, głównie wyraz „potencja” przypomina na każdym kroku Schellinga. Można więc powiedzieć, że wprawdzie System moralności powstał jako dalszy konsekwentny rozwój systemu w Frankfurcie skoncypowanego, że jednak sposób jego nakreślenia byłby inaczej wypadł, gdyby nie pobyt w Jenie i wpływ Schellinga. Trudno byłoby to śledzić w szczegółach; na jedno tylko zwracam uwagę. Owa dialektyka, która w Frankfurcie ma znaczenie podmiotowo-przedmiotowe, a bardziej przedmiotowe aniżeli podmiotowe, albowiem przedstawia faktyczne przetapianie [s. 72] się różnych form bytu, teraz otrzymuje charakter przeważnie podmiotowy jako instrument poznania objawiającego się $\mathrm{w}$ różnych formach absolutu. Toteż cały system ma charakter konstrukcji podmiotowej, a nie rozwoju przedmiotowego; a właśnie ta podmiotowa konstrukcja jest jedną z głównych cech filozofii Schellinga ${ }^{176}$. Formalizm, schematyzm, mania klasyfikacji. Kilka jeszcze słów o całym układzie Systemu moralności: A. Moralność absolutna według jej stosunku, tj. jako niedoskonałe jeszcze zjednoczenie szczegółów i ogółu. Jest to nauka o moralności przyrodzonej, B. Strona negatywna, czyli wolność, czyli zbrodnia. C. Moralnośćc 177 . 
A. Moralność absolutna według jej stosunku, jako stosunek objawia się w różnych potencjach, postaciach, stopniach urzeczywistnienia się. I. Pierwsza potencja, to moralność przyrodzona jako wyobrażenie, poczucie praktyczne. Objawia się jako (a) szereg potrzeb, prowadzących do (b) pracy, a ta praca znowu trojaka w swych rezultatach itd. II. Druga potencja, gdzie praca nie tylko wytwarza dobra dla zaspokojenia potrzeb, ale też dobra zbytkowe itd. ${ }^{178}$ B. Strona negatywna przeciwienstwo między [s. 73] jednostką a ogółem bywa zniesione na korzyść jednostki. Znowu szereg potencji, prowadzących do klasyfikacji i definicji różnych zbrodni ${ }^{179}$. C. Jeżeli przeciwieństwo między jednostką a ogółem bywa zniesione na korzyść ogółu. I znowu różne potencje: Moralność absolutna w stanie spoczynku, to forma ustroju politycznego. Konstytucja w najszerszym znaczeniu. Gdy rozważamy ją w ruchu, wtedy to jest samo rządzenie, czynniki rządu. $Z$ tym się łączy podział na trzy stany: Stan waleczności, czyli arystokracja, szlachta; stan uczciwości, czyli stan mieszczański; stan zaufania, czyli stan rolniczy. Ciekawa też uwaga, że nie należy dzielić władzy ustawodawczej, wykonawczej i sądowniczej. A zadania rządu znowu jako zadania dla zaspokojenia 1) systemu potrzeb, 2) systemu sprawiedliwości, 3) systemu kształcenia (do czego też zalicza wychowanie, naukę, środki policyjno-administracyjne, dalej wyrobienie karności, czynność kolonizacyjna $)^{180}$.

([Kontynuacja wykładu za] Haymem, IX ${ }^{181}$ )

Ten dział filozofii, mianowicie filozofia moralności pierwszy [został] opublikowany ${ }^{182}$. W „Kritisches Journal der Philosophie” znajduje się na końcu artykuł obszerny: Ueber die wissenschaftlichen Behandlungsarten des Naturrechts, seine Stelle in der praktischen [s. 74] Philosophie und sein Verhältnis zu den positiven Rechtswissenschaften"183. Tu jednak też nieco inne ugrupowanie i rozczłonkowanie. Jako druga część nie występuje zbrodnia, czyli występek, lecz tak: pierwsza część - dziedzina życia praktycznego (potrzeba, praca, posiadanie) ${ }^{184}$; druga część - sfera prawa ${ }^{185}$; trzecia część - sfera moralności ${ }^{186}$. Tu zarazem stanowczo i wyraźnie państwo występuje jako „duch absolutnie żywy"187; poza państwem, w którym jako w absolutnej moralności "najprawdziwiej jednoczy się absolutna forma z absolutną substancją" 188 , nic w ogóle już dalszego nie ma; religia tak jak w owych rękopisach tylko uświadomieniem sobie, odzwierciedleniem moralności, ujawniającej się w życiu państwowo-społecznym. Po raz pierwszy natomiast występuje tutaj historia ${ }^{189}$. Ale także z tego moralno-politycznego punktu widzenia. Różne formy państwowości, kolejno występujące, są różnymi formami urzeczywistniania się ducha świata, absolutu. W całości, w totalności tych form urzeczywistnienia się ducha świata mamy drugą i końcową konsumację idei ducha, postulowanej przez logikę i metafizykę. Tak więc natura fizyczna [s. 75] i natura moralna znowu występują jako dwie jedynie możliwe formy, w których się przejawia absolut; znowu ich trychotomia: absolutny duch, objawia- 
jący się w przyrodzie, objawiający się i powracający do siebie w świecie moralności. A ustosunkowania oczywiście takie, że natura moralna wyższa od fizycznej; albowiem istota absolutu polega na „nieskończonej ekspansji i nieskończonym skupianiu tej ekspansji w sobie samym". Otóż ekspansja to przyroda, skupianie się, to absolutna moralność. Tak więc tutaj występuje bardzo jasno stosunek tej filozofii moralności do poprzednich części systemu. Co w rękopisach raczej jako chronologiczne następstwo działów jego filozofii się przeciwstawiało, to tutaj jako organiczny związek występuje ${ }^{190}$.

\section{Wykład dwunasty z 10 lutego 1905 roku}

Zarazem jednak $\mathrm{w}$ tej rozprawie inna jeszcze rzecz uzupełniona: mianowicie stanowisko inteligencji w systemie absolutu. W rozdziałach rękopiśmiennych, traktujących o filozofii przyrody, konstruuje Hegel przyrodę z eteru ${ }^{191}$. Cały ten proces ma wykazać, że w przyrodzie odbywa się stopniowy pochód od poznania do samopoznania (Das Werden der Erkenntnis). Przeciwstawienie bowiem przyrody absolutnemu duchowi daje mu przedmiot [s. 76] poznania wiedzy; ale ten duch absolutny musi dojść do samopoznania w sferze moralnej; więc przyroda właśnie prowadzi od tego poznania, aż do progu filozofii moralności. Otóż w rozprawie, o której mówimy, wywodzi Hegel między innymi, że właśnie $\mathrm{w}$ inteligencji realizuje się poznanie; albowiem dopiero $\mathrm{w}$ inteligencji proces indywidualizowania stopniowego, wytwarzający wszelkie formy istnienia w przyrodzie, dochodzi aż do absolutnego swego zaprzeczenia, do możności uogólnienia. Ta możność uogólnienia w połączeniu $\mathrm{z}$ absolutem jednocześnie znajduje zaś swój najpełniejszy wyraz w moralności, gdzie właśnie jednostka w każdym konkretnym czynie wyraża najogólniejsze prawa moralne; za czym moralność jest właśnie urzeczywistnieniem inteligencji. A ponieważ inteligencja jest wynikiem procesu przyrodzonego, więc moralność jest tym samym też urzeczywistnieniem, prawdą, przyrody i absolutnie-absolutnym urzeczywistnieniem idei absolutnego ducha ${ }^{192}$.

Ale te wszystkie wywody, wyjaśnienia i konstrukcje są tylko jedną stroną tej rozprawy i wielu innych w „Kritisches Journal der Philosophie” ogłoszonych. Druga strona: polemiczno-krytyczna. [s. 77] I w ogóle cały szereg rozpraw takich $\mathrm{w}$ "Journalu". Albowiem potrzeba sprecyzowania swego stanowiska względem innych poglądów, co już rozpoczęto w pracy o różnicy systemu Fichteańskiego i Schellingiańskiego. Mamy więc na przykład: Glauben und Wissen oder die Reflexionsphilosophie der Subiectivität in der Vollständigkeit ihrer Formen als Kantische, Jakobische und Fichtesche Philosophie ${ }^{193}$. Albo: Wie der gemeine Menschenverstand die Philosophie nehme, dargestellt an den Werken des Herrn Krug ${ }^{194}$. Albo: Rückert und 
Weiss, oder die Philosophie, zu der es keines Denkens und Wissens bedarf (autorstwo Hegla wattpliwe) ${ }^{195}$ itd. Poznanie w najogólniejszych zarysach stanowiska krytycznego Hegla oświetli nam pod jednym względem jego własne stanowisko ${ }^{196}$. Przede wszystkim co do stanowiska ogólnego krytyki filozoficznej Hegel jest zdania, że jak krytyka artystyczna nie stwarza dopiero dzieła sztuki, lecz je suponuje, tak też krytyka filozoficzna. A zarazem przekonanie, że jak piękno jest jedno, tak też i filozofia tylko jedna jest, i że tą jedną filozofią jest filozofia absolutu, filozofia przez niego głoszona. Nie istnieją różne filozofie, lecz [s. 78] jest jedna filozofia, a wszystko inne [jest] tylko pozorną filozofia, więc w gruncie rzeczy nie-filozofią. Tak więc krytyka nie może być stronnicza, nie może być polemika, gdyż walczy z przeciwnikami wcale nie równorzędnymi, lecz pozorami. Filozofia prawdziwa tym, że się zjawia, niszczy od razu wszelkie pozorne filozofowanie. Przypomina to ową pewność siebie romantycznych jednostek genialnych, owo poczucie siebie Schlegla i innych. Filozof staje na stanowisku bardzo wzniosłym i wysokim, z którego z pewnym politowaniem spogląda na usiłowania tych wszystkich, co także chcą być filozofami i sądzą, że na to wystarczy pewne oświecenie umysłu i zdrowy rozsądek. $Z$ tego stanowiska więc krytykuje się poglądy Kanta, Fichtego, Reinholda, Jakobiego i Herdera, Schleiermachera i wielu innych. Kanta i Fichtego z pewnym respektem, tamtych z ironią, sarkazmem i złośliwością ${ }^{197}$. Co do Kanta: Krytyka wskazuje, że on wprawdzie przeczuwał miejscami prawdziwą filozofię, ale zawsze znowu od niej odbiegł. Prawdziwa filozofia polega na przekonaniu, że podmiot i przedmiot $\mathrm{w}$ gruncie rzeczy jednym i tym samym, że są absolutem, absolutnym duchem. Otóż to mamy u Kanta zaznaczone na przykład w pojęciu piękna i celowości organicznej; [s. 79] a najbardziej w pojęciu "rozumu wyobrażającego", w pojęciu „wyobrażenia intelektualnego" ${ }^{\prime 198}$. Ale Kant to pojęcie uważa za niczym nie dające się uzasadnić przypuszczenie, za pomysł, realności jego nie uznaje, i tak myśl, która była prawdą i byłaby go zaprowadziła do prawdziwej filozofii, znowu porzucił. Więc nie doszedł do prawdziwej filozofii. A całkiem podobnie ma się rzecz z Fichtem. I ona, filozofia Fichtego dotknęła się prawdy, a potem znowu ją zepsuła, od siebie odrzuciła. W punkcie wyjścia, w absolutnej jaźni, która jest podmiotem, a przedmiotem zarazem $\mathrm{o}$ ile $\mathrm{w}$ niej ten przedmiot drzemie, Fichte zupełnie chwycił prawdę. Ale zarazem potem się z nią rozstał. Albowiem dowodzi nam dalej, że właśnie w świecie identyczności tej nie ma między podmiotem i przedmiotem, że raczej podmiot musi sobie poddać przedmiot, że w nieskończonym procesie historycznym to ponowne zjednoczenie przedmiotowej strony bytu z podmiotową musi się iścić. A tym samym opuścił on zasadnicze twierdzenie filozofii prawdziwej, że podmiot i przedmiot są tym samym, identyczne ${ }^{199}$. Podobnie potem innych filozofów rozbiera i ocenia. - Ale to nasuwa pytanie, jakim prawem Hegel tak krytykował. 
Mówi [s. 80] nam o swej prawdziwej filozofii; ale czy uzasadnia jej prawdziwość? Czy czuje się do tego uzasadnienia w ogóle zobowiązanym? Otóż tutaj, w owej fazie swego filozofowania wprost odrzuca żądanie takiego uzasadnienia. Wyśmiewa Reinholda, który chciał filozofii Kanta dać lepsze uzasadnienie: Ergründungs- und Begründungstendenz ${ }^{200}$. Aby dojść do filozofii, trzeba uczynić w nią skok à corps perdu, na oślep, z pieca na łeb. Rozum bowiem tym tylko wznosi się do filozoficznej spekulacji, że „wznosi się sam do siebie, że powierza się sam sobie i absolutowi, który jest jego przedmiotem" ${ }^{\prime 201}$. W tym znaczeniu absolut jest wprost założeniem wszelkiej filozofii, którego szukać można tylko dlatego, że już istnieje przed wszelką filozofia, a szuka i znajduje się absolut w ten sposób, że rozum uwalnia się od świadomości wszelkich ograniczeń, wszelkich negacji, wszelkich skończoności, tkwiących właśnie w nie-absolucie. Żądanie dowodzenia absolutu nazwał wprost bezczelnością i ograniczeniem głównym prostego rozumu chłopskiego, który swe żądania, ważne dla świata skończonego rozszerza i rozciaga także na sferę absolutu. ([odwołanie bezpośrednie do] Hayma, 190202).

[s. 81] Prawda, że Hegel sam nie od razu do tego absolutu doszedł, w którego objęcia każe się teraz adeptom filozofii rzucać od razu, jednym zamachem. W swej logice i metafizyce (rękopis frankfurcki) stopniowo doń doszedł, a wiele rzeczy przemawia za tym, że w swych wykładach w Jenie wyznaczał właśnie logice zadanie dowiedzenia i uzasadnienia tego stanowiska filozofii absolutu, ducha absolutnego ${ }^{203}$. Wszelako w swych publikacjach w „Kritisches Journal” nie ma ani śladu dowodu albo uznania potrzeby dowodu. Tu zaczyna się wszystko od "postulatu” „prawdziwego wyobrażenia intelektualnego", wyobrażenia, w którym wszechświat i wszystko przedstawia się jako identyczność bytu idealnego i realnego, wyobrażenia, które Kant znał jako właściwość hipotetyczną hipotetycznego intellectus archetypus ${ }^{204}$. Co najwyżej otrzymuje pewne wskazówki, jak to mamy uczynić, aby ów postulat spełnić, podobnie jak Schelling już był postąpił, aby wyrwać się ze stanowiska „subiektywnego" filozofii Kantowskiej i Fichteańskiej. W tej filozofii bowiem stoimy na stanowisku świadomości, na stanowisku więc podmiotowym. Aby się z tego stanowiska wydobyć, aby dojść do [s. 82] czystego wyobrażenia intelektualnego, musi refleksja filozoficzna abstrahować od tego czynnika podmiotowego; $w$ ten sposób „owo wyobrażenie transcendentalne jako podstawa filozofii nie będzie miało ani podmiotowego, ani przedmiotowego charakteru, nie będzie samowiedza, przeciwstawioną materii, ani materia, przeciwstawioną samowiedzy, lecz będzie czystą i absolutna, ani podmiotowa ani przedmiotową identycznością" ${ }^{205}$. - Ale oczywiście, taki postulat i nawet najbardziej szczegółowe wskazówki jego spełnienia nie zastępują dowodu. Proszę zważyć, jaki stosunek tego wszystkiego do Fichtego. U Fichtego to wszystko, co on rzekł, miało własną rację, o ile chodziło o uzyskanie absolutnie pewnego punktu oparcia. 
Żądając, byśmy stanęli na stanowisku czystej samowiedzy, daje wyraz przekonaniu, już przed nim tylekrotnie wyrażonemu, że nasze ",ja”, ów substrat samowiedzy, nieodłącznie towarzyszy wszelkiemu myśleniu, że nie możemy się go pozbyć. Jaźń nasza jest więc niewzruszoną podstawą wszelkiego filozofowania ${ }^{206}$. Natomiast u Hegla, podobnie, jak u Schellinga, właśnie mamy od tej podstawy, od tej jaźni abstrahować, mamy świadomość i [s. 83] samowiedzę zmusić do milczenia, usunąć na bok, wyzbyć się jej. Mamy, reflektując i myśląc, abstrahować od tego, co reflektuje i myśli. Czy jest to możliwe, czy możliwe coś analogicznego? Tak, w różnych chwilach życia. W sztuce, gdy oglądając dzieło sztuki, z wszystkim niejako się rozpływamy w nim, o sobie zapominamy. Tak samo w chwilach ekstazy religijno-mistycznej. W tej ekstazie następuje owa haplosis, henosis nowoplatończyków; owe zlanie się jednostki z Bogiem, absolutem. I tu znowu widzimy, jak stanowisko filozoficzne Hegla, tak jak Schellinga, wyrasta właśnie z czynników pewnych pozafilozoficznych ${ }^{207}$. Sztuka, estetyczne zachowanie się wobec świata, oto świat grecki. A ekstaza religijna, to, jak widzieliśmy w młodym teologu Heglu także miało podstawy. U Schellinga więc intelektualne wyobrażanie jest skokiem ze sfery sztuki w sferę filozofii. U Hegla jest to skok ze sfery sztuki i religii $\mathrm{w}$ sferę filozofii. $U$ jednego i drugiego mamy tu więc pomieszanie, i spojenie rzeczy i różnych punktów widzenia. To pomieszanie rzeczy do siebie nienależących da się oczywiście genetycznie rozumieć, da się wyjaśnić, ale [s. 84] takie wyjaśnienie nie jest uzasadnieniem ${ }^{208}$.

\section{Wykład trzynasty z 17 lutego 1905 roku}

Mimo to Hegel jest tego zdania, że jego stanowisko jest słuszne i jedynie uzasadnione. Co więcej, jest tego zdania, że nie może być o tym wątpliwości. A nawet znajdujemy w nim poczucie potrzeby pewnego uzasadnienia, co prawda pozornego tylko, które w gruncie rzeczy uzasadnieniem nie jest. Mianowicie uprawnienie intelektualnego wyobrażenia ma wyniknąć z tego, że właśnie stając na stanowisku tego intelektualnego wyobrażenia i z niego wychodząc, można dojść do zaokrąglonego, harmonijnego systemu, obejmującego wszechświat i będącego najpełniejszym jego wyrazem. Więc fakt oparcia takiego systemu na wyobrażaniu intelektualnym ma dowieść, że ten punkt wyjścia jest słuszny. To wygląda tak, jak gdyby rzekł artysta: Kto wątpi, że mam talent, ten niech spojrzy na me dzieło. Skoro mogłem stworzyć prawdziwe dzieło sztuki, więc to, na czym się ono we mnie opiera, ma rację bytu, jest prawdziwym talentem. Mamy tu więc poniekąd znowu podstawienie artystyczno-estetycznego punktu widzenia w miejsce logicznego. - Otóż w swych [s. 85] krytycznych i polemicznych artykułach właśnie stara się 
wykazać, jak zwalczane przez niego systemy filozofii grzeszą brakiem tego, co on uważa za dowód racji bytu swego własnego, jak grzeszą brakiem zaokrąglenia, wykończenia, jak są czymś połowicznym, sztucznym, martwym, pokawałkowanym i rozerwanym, bez jedności, całości i harmonii. Przede wszystkim zamiast zjednoczenia myśli i rzeczywistości, filozofii i życia mamy w nich rozdwojenie, martwotę formalizmu, nieuchwytność życiową transakcji. I tak na przykład Kant w swej etyce zamiast o woli, o chceniu i dążeniu człowieka mówi o formie woli, abstrahując od wszelkiej konkretnej treści naszego chcenia ${ }^{209}$. Oburza się na takie rozkawałkowanie tego, co w rzeczywistości tworzy jedną całość, jak właśnie forma i treść woli; oburza się na powstające stąd operowanie samymi wyrazami i słowami. I twierdzi, że to, co wynika z filozofii, musi się dać bezpośrednio zastosować do życia, musi być zgodne z potocznym sposobem wyobrażania, musi być czymś konkretnym, żywym, rzeczywistym. Tymczasem co widzimy u Fichtego? Rozerwanie jaźni i przyrody, podmiotu i przedmiotu; tak samo jak u Kanta rozerwanie [s. 86] dziedzin piękna i dobra. „System tyranii i rozbratu piękna i dobra" ${ }^{210}$. - To wszystko bardzo piękne i czyta się z pewną może nawet satysfakcją; ale to nie może nas przekonać, że filozofia Hegla także nie jest tylko systemem abstrakcyjnym, że i ona nie jest pełną rzeczywistościa, lecz operowaniem pojęciami oderwanymi. I nie pomoże tu także konstrukcja historyczna, która również ma wykazać jedyne prawo bytu i jedyną rację istnienia właśnie dla systemu Hegla. Hegel rozwodzi się i zdaje sobie sprawę o swym stanowisku w pochodzie filozofii. On swoją filozofię historycznie wywodzi z przeszłości. To przykład jedyny w swoim rodzaju. Wiemy już, że w ogólnym pochodzie tej filozofii Hegel upatruje epokę grecka, jako harmonijna, po czym następuje naruszenie harmonii; po części znowu stworzenie harmonii tej w chrześcijaństwie, ale w miarę, jak intelektualne założenia się zmieniły, na gruncie których chrześcijaństwo mogło dać owo harmonijne zjednoczenie skończoności i nieskończoności, znowu rozdwojenie i niepokój. Otóż filozofia Hegla ma ponownie dać owo zjednoczenie. - Ale nie tylko w tej ogólnej historycznej perspektywie [s. 87] Hegel konstruuje swe stanowisko, lecz także pod względem stosunku do swego czasu i do bezpośredniej przeszłości. Mianowicie wykazuje, jak nowożytna kultura umysłowa wyrosła z zasady protestantyzmu, jak dalej ta zasada i wyrosła z niego kultura ma charakter przede wszystkim podmiotowy, wyrażający się $w$ tęsknocie za wiecznym pięknem i wiecznym szczęściem, a nie w zaspokojeniu tej tęsknoty w bezpośrednim niejako oglądaniu wiecznego piękna i w posiadaniu szczęścia. Stąd ograniczenie do doczesności i skończoności (albowiem tylko doczesność i skończoność może człowiekowi zastąpić ową niedoścignioną, wieczną piękność). Stąd eudajmonizm, stąd dążenia wieku oświecenia, zmierzające właśnie, aby drogą intelektualnej kultury zapewnić człowiekowi doczesne szczęście. I na tym gruncie wy- 
rosła też filozofia Kanta, Fichtego, Jakobiego. To, co skończone, uczynili oni absolutem; poza to sięgnąć nie pozwalaja i stąd wytworzyli ostre przeciwieństwo absolutu i skończoności, realności i idealności, i właściwie tylko w dalszym ciągu poprowadzili dzieło Locke'a i Voltaire'a. Jak w dramatach Kotzeubego i Ifflanda wzdychaja, oczy ku niebu [s. 88] ([Bezpośrednie odwołanie do] Hayma, 204211) wznoszą i poza tym pozostają na ziemi. Ale właśnie dlatego nadszedł czas dla filozofii nowej, w której by myśl nie była cieniem tylko, lecz rzeczywistościa, pierwiastkiem organizującym rzeczywistość, w której wynagrodzono by przyrodzie zniewagę wyrządzoną jej przez filozofię Kanta i Fichtego, w której rozum sam pozostawałby w żywej i serdecznej zgodzie z przyrodą. Że nadszedł czas dla takiej filozofii, na to wskazują liczne objawy, z których najwybitniejszym jest stanowisko, które zaczyna sobie zdobywać sztuka, poezja. A filozofią tą jest „absolutny idealizm”, stający ręka w rekę z budzącym się do nowego życia ruchem na polu sztuki. Absolutny idealizm jest zwiastunem czasu, w którym istnieć znowu będzie „wolny lud"212. A skoro będzie ten wolny lud, także nowa powstanie religia, wytworzona przez pogląd na świat absolutnego idealizmu. Nowa ta religia zastąpi religię samej tylko tęsknoty, protestantyzm. Wszak już sam idealizm absolutny jest właściwie powrotem do pogody umysłowej i czystości serca greckiego poglądu na świat ${ }^{213}$.

Znowu więc wszystko się skupia i organizuje w ideale świata klasycznego. Ten świat klasyczny tak mu się wydaje pożądania godnym, [s. 89] że całe życie według niego w społeczeństwie chce urządzić i że dla Niemców kreśli ideał państwa rysami tak pokrewnymi obrazowi platońskiego państwa ${ }^{214}$. Ten ideał klasyczny w ogóle tak go opanowuje, w formie spotęgowanej uczuciowością pewną romantyki, że z tego punktu widzenia na wszystko patrzy i wszystko ocenia. Na przykład występuje w jego stanowisku ówczesnym względem katolicyzmu. Jest Heglowi sympatyczniejszy od protestantyzmu ${ }^{215}$. Uważa, że w katolicyzmie chrześcijaństwo stało się religią piękną, co następnie w wykładach swych ówczesnych szeroko i z pewną lubością uzasadniał. Stawiał go wyżej od protestantyzmu. W katolicyzmie widzi jeszcze identyczność podmiotu i przedmiotu; w protestantyzmie natomiast sam subiektywizm. A takie sądy znowu oświetlają nam stanowisko Hegla względem Schellinga i całej romantyki, z jej tęsknotą za średniowieczem, dymem kadzideł, pełnym brzmieniem dzwonów, półcieniem witraży itd. ${ }^{216}$ ([Kontynuacja rozważań za] Haymem, X217)

Ale już niedaleki był koniec tego sojuszu z Schellingiem i romantyką. Schelling bowiem i z nim filozofia romantyzmu zaczęła kroczyć drogami, po których Hegel nie mógł za nimi pójść. Coraz bardziej frazeologia, formalizm, dowolność najzupełniejsza zamiast logicznie, naukowo budowanych i przeprowadzanych [s. 90] wywodów. Fantazja, mistycyzm, zarozumiałość, mętność, to wszystko coraz wyraźniej sta- 
wało się znamieniem tej filozofii. Otóż tego zaczynało być niebawem Heglowi za wiele, gdyż przecież tradycje, w których on się wychował, w których się jego umysł ukształtował, bądź co bądź pragnęły pewnej rozumniej prawidłowości, nie mogły abdykować z rozumu na rzecz samego marzycielstwa. I to, co w innych warunkach byłoby może bardzo trudne, stało się dla Hegla o tyle łatwiejsze, że Schelling w roku 1803 opuścił Jenę, ożeniwszy się z rozwiedziona, o 12 lat od niego starszą żoną A. W. Schlegla, aby objąć profesurę w Würzburgu ${ }^{218}$. Skoro ustał codzienny kontakt osobisty, zaczęła się przygotowywać wielka reakcja w duchu Hegla, zwrot bardzo stanowczy. Zaczął krytycznym wzrokiem patrzeć na filozofię absolutnego idealizmu. Jak poprzednio razem z Schellingiem krytycznie rozpatrywał i zwalczał filozofię Kanta, Fichtego, Jakobiego, Herdera, Reinholda, Schleiermachera i innych, tak teraz krytycznie zwrócił się przeciwko filozofii romantyki, filozofii Schellinga. To co przedtem uważał za ostatni wyraz filozofii, teraz stawało mu się okresem przejściowym, coraz wyraźniej [s. 91] uświadamiał sobie, że nie wystarczy kruszyć kopii w obronie piękna, lecz że trzeba także utorować drogę prawom rozumu. Pracę tę zaczął Hegel niemal zaraz po odejściu Schellinga z Jeny. Cały niemal swój czas poświęca teraz wykładom, gdy przedtem liczne artykuły w czasopiśmie wiele mu czasu absorbowały. Rok rocznie wykłada teraz cały swój system filozofii, ogłoszony jako „Philosophiae systema universum” 219 albo jako „Tota philosophiae scientia"220, a zawierający logikę i metafizykę, filozofię przyrody i filozofię ducha. W tych wykładach z ustawicznym kontaktem nie z Schellingiem już, lecz z uczniami, odczuł także potrzebę, którą przedtem sobie lekceważył, potrzebę metody $\mathrm{w}$ filozofii $\mathrm{w}$ tym znaczeniu, by wprowadzić młodzież w swój gmach myśli, a nie wymagać z taką pewnością siebie od uczniów, jak wymagał tego od publiczności, by od razu, z pieca na łeb, skoczyła w absolut, a zarazem wzniosła się do intelektualnego wyobrażania absolutu. Odczuł potrzebę przeprowadzenia dowodu, że jego stanowisko jest słuszne, że tak, a nie inaczej trzeba poczynać sobie z filozofią. Owocem tego zasadniczego zwrotu, prowadzącego zarazem do systemu Hegla [s. 92] w tej postaci, w której system ten do potomności przeszedł, było wydane w roku 1807 dzieło pt. Phänomenologie des Geistes ${ }^{221}$. (Zewn. okoliczności druku i wydania zob. K. Fischer, VIII, 1. pg. $68^{222}$ ). W lutym 1806 druk rozpoczęty, skończony w styczniu 1807. Wykończenie rękopisu przypadło właśnie w październiku 1806, kiedy to 14 października rozegrała się bitwa pod Jeną 223 . Hegel widział wtedy na własne oczy Napoleona i pisze o tym dnia 8 października: „Cesarza, tę duszę świata, widziałem udającego się konno przez miasto na rekonesans; jest to istotnie dziwne uczucie, gdy się widzi takiego osobnika, siedzącego tu na koniu, skoncentrowanego $\mathrm{w}$ jednym punkcie, a przecież obejmującego cały świat i nad całym światem panującego" ${ }^{224}$. Pełen podziwu. - A w liście do Schellinga, dnia 1 maja, przesyłając mu egzem- 
plarz fenomenologii, pisze: „Brak wykończenia ostatnich partii zechciej pobłażliwie wybaczyć także i z tego względu, że ukończyłem redakcję dzieła w ogóle o północy przed bitwą pod Jeną" 225 . Nie tylko dzieło, lecz i sam Hegel ucierpiał wskutek tej bitwy, gdyż należał do tych, których wojsko francuskie zupełnie splądrowało; Goethe kazał mu z tego powodu doręczyć 10 talarów, bo Hegel nie miał co jeść226.

\section{Wykład czternasty z 24 lutego 1905 roku}

[s. 93] Znamienna Przedmowa do Fenomenologii ducha. Obszerna, 101 stron. Jest ona wyraźnym, stanowczym zerwaniem z kierunkiem Schellinga $\mathrm{w}$ filozofii ${ }^{227}$. Nigdzie nazwisko Schellinga nie jest wymienione; ale nigdzie nie może być wątpliwości, że jego [Hegel] ma na myśli. A właśnie, nie wymieniając Schellinga, zawarował sobie w ogóle możność tak stanowczej polemiki i krytyki swego do niedawna przyjaciela. Można by, jak słusznie zauważa Haym, nazwać tę Przedmowę rozprawą z Ueber die Differenz des Schellingschen und Hegelscher Systems der Philosophie $e^{228}$. Jest to przedmowa programowa, dla całej dalszej działalności Hegla charakterystyczna, zarazem najlepiej nam objaśniająca jego intencje. Zwraca się przede wszystkim przeciw owej manii genialności, która zrazu w poezji obóz swój roztoczyła, ale „zamiast poezji, o ile w ogóle twórczość tej genialności miała jakiś sens, wytwarzała trywialną prozę albo, o ile się ponad nią wznosiła, wariackie elokubracje"229. Ale tak właśnie dzieje się obecnie z filozofia, gdzie owa genialność [s. 94] się rozpanoszyła. Filozofowanie „które wyniośle i z góry spogląda na pojęcie, a wskutek braku pojęcia uważa się za myślenie obrazowe i poetyckie, rzuca na targ dowolne kombinacje wyobraźni, zdezorganizowanej tylko myśleniem, a kombinacje te nie są ni rakiem i ryba, ni poezja, ni filozofią"230. Przeciw tej pseudofilozofii na każdej stronie wycieczki. „Piękno, Świętość, Wieczność, religia i miłość, oto wędki, których potrzeba, aby wywołać chęć zakosztowania (tej filozofii); nie pojęcie, lecz ekstaza, nie trzeźwo krocząca naprzód konieczność rzeczowa, lecz wrzący zapał, oto ma być zachowanie się i rozszerzanie się bogactwa, tkwiącego w substancji" ${ }^{\prime 231}$. Z pogardą owa prorocza i wieszcza gadanina spogląda na wszelkie określenie, na wszelką ścisłość; z dala trzyma się od pojęcia, od konieczności, od refleksji, gdyż rzeczy te to cechy skończoności. A właśnie w obronie tych rzeczy z całą stanowczością występuje Hegel: Określenie, miara, forma, pojęcie, refleksja! Tylko w pojęciu, powiada, „prawda dla siebie ma czynnik istnienia”"232, czyli prościej: tylko w pojęciu prawda może znaleźć swe uzasadnienie i swój wyraz.

Nie trzeba bujać, wyobraźnią się upajać, lecz trzeba [s. 95] „poważnej, cierpliwej, przykrej niekiedy pracy"233. Filozofia nie ma wzbudzać nabożeństwa, lecz wiedzę. Przeciw formalizmowi, który jest brakiem 
wszelkiej formy, zwraca się w obronie formy. Zaleca jako konieczną rzecz analizę i rozróżnianie, dystynkcje. Nie chce, by mieszano i gmatwano tego, co myśli „wyróżnia”. Sam do niedawna w „Kritisches Journal” lekceważąco o zdrowym rozsądku się wyrażał; teraz śpiewa mu hymny pochwalne. Tylko „piękno bezsilne nienawidzi rozumu, albowiem rozum żąda od niego, czego ono nie potrafi" ${ }^{234}$; ale w istocie rozum, wyposażony w zdolność rozróżniania, jest „najbardziej podziwu godna, największa, a raczej absolutną potęgą" ${ }^{235}$. A zgodnie z taką czcią dla rozumu czci teraz też zrozumiałość, zwracając się przeciw wszelkiemu ezoteryzmowi, przeciw filozofowaniu dla szczupłego grona wybrańców wtajemniczonych, jakie właśnie uprawiała nowa filozofia w swej pustej zarozumiałości. Filozofia jako nauka rozumowa z istoty swej dla wszystkich jest przeznaczona. Nie prowadzi do niej jakaś droga królewska, tj. otwarta tylko dla wybrańców; istnieje droga wszystkim dostępna, dla wszystkich równa, a tą drogą jest właśnie uprzystępniona rozumową formą [s. 96] nauki droga prawdy. Albowiem tylko to, co ,,jest pod każdym względem określone, jest zarazem egzoteryczne takie, że można się tego nauczyć i że może się stać własnością powszechną"236. - Ale Hegel wyraża się jeszcze dobitniej i jeszcze silniej przeciwstawia swoje zamiary filozofii Schellingiańskiej. W filozofii Schellinga uchodzi za spekulatywny sposób rozważania rzeczy właśnie to, że usuwa się wszystko, co jest wyróżnione i określone. „Rozważać jakiś byt takim, jakim jest $\mathrm{w}$ absolucie, polega tu na tym, że się mówi, iż właśnie teraz była o nim mowa, jako o czymś; ale $\mathrm{w}$ absolucie, $\mathrm{w}$ owem $\mathrm{A}=\mathrm{A}$, nie ma nic takiego, tam wszystko jest jednym. Otóż takie przeciwstawianie tej jednej wiedzy, że $\mathrm{w}$ absolucie wszystko jest sobie równe, poznaniu rozróżniającemu, posiadającemu jakąśs treść, albo też to przedstawianie swego absolutu jako nocy, w której wszystkie krowy są czarne, to nie jest niczym innym jak naiwnością, wynikającą z pustki rozumowej" ${ }^{237}$. Naturalnie, że Hegel nie ma dość słów potępienia dla owego formalistycznego schematyzowania, przy pomocy którego wszystko ma być z absolutu wyprowadzone; [s. 97] powiada na przykład: „Jeżeli na przykład formalizm przyrodniczy twierdzi, że rozum jest elektrycznością albo że zwierzę jest azotem, albo że równa się północy i południowi itd. Albo że je reprezentuje, jeżeli formalizm ów wypowiada te twierdzenia tak sobie w nagiej postaci, jak tu właśnie, albo jeżeli je też zaprawi obszerną terminologia, wtedy nad taką siła, obejmującą rzeczy sobie tak dalekie w jednym poglądzie, może brak doświadczenia wpadać w pełen podziwu zachwyt, może czcić w tym głeboką genialność, może też radować się zabawnością takich określeń i pogratulować sobie, że czuje się spokrewniony z tak wspaniałym sposobem postępowania”. "Ale mechanizmu tej mądrości nie trudno się nauczyć, nie trudno też samemu nim się posługiwać; ale skoro raz się ten mechanizm zna, powtarzając go, wywołuje się tak samo nieznośne nudy, jak powtarzaniem sztuczki kuglarskiej, której mechanizm już zna- 
my" 238. "Narzędziem tego monotonnego formalizmu nie trudniej się posługiwać jak paletą malarza, na której byłyby tylko dwie barwy: czerwona i zielona, aby zasmarować płótno barwą czerwoną, gdy to ma być [s. 98] obraz historyczny, a zielona, gdy to ma być pejzaż" ${ }^{239}$. Więc przeciw wszelkiej dowolności, przeciw wszelkiemu fantazjowaniu, a w obronie, ścisłości, metodyczności, w obronie systematyczności. Wyraźnie powiada: „Prawdziwa forma, w której jedynie istnieje prawda, to jest system naukowy" ${ }^{240}$. (I dlatego też Fenomenologia ducha ma na tytule: System der Wissenschaft, I. Teil, Phänomenologie d. G. $)^{241}$. - Ale zapytacie Państwo, jak stoi sprawa z historyczną konstrukcją Hegla, który przecież poprzednio dowodził, że filozofia absolutnego idealizmu właśnie dziejową koniecznością jest? Powiadał, że stanąć na tym samym stanowisku absolutnego idealizmu było dla Hegla odnowieniem sposobu myślenia i poglądów, panujących dawniej w klasycznym świecie greckim, a potem w chrześcijaństwie; stanowisko absolutnego idealizmu było dla Hegla przezwyciężeniem protestantyzmu i filozofii oświecenia wraz z filozofią refleksji Kanta, Reinholda, Fichtego. Filozofia absolutnego idealizmu była dla niego równoznaczna z uzasadnieniem filozoficznym okresu odczuwania estetycznego, czci dla piękna, które właśnie wówczas w dość barbarzyńskich przedtem pod tym względem w Niemczech zaczęło się budzić $^{42}$. Więc cóż z tą całą konstrukcją? Otóż nie [s. 99] inaczej teraz konstruował historycznie swe stanowisko. To prawda wszystko, co mówił. „Duch istotnie ruszył się i wysunął się ponad swą poprzednią postać" ${ }^{243}$. Cała ta masa dotychczasowych pojęć i poglądów rozluźniła się, zapada się jak mara senna w nicość (pamiętajmy, że Hegel patrzył na rewolucję polityczną francuską i na rewolucję pokojową poezji klasyków i romantyków niemieckich). Więc filozofia musi też tę nową epokę powitać, uznać, zrozumieć, wyrazić. A istotną cechą tej nowej epoki jest to, że zadowolenie estetyczne zaczyna znowu powracać w serca i umysły ludzkie i z resztą natury człowieczej w jedną całość zaokrągloną się zlewać. Ale zaczyna się. Stoimy dopiero na początku tej nowej epoki. Tylko dlatego, że rozerwanie i rozdźwięk poprzednich epok dał się nam tak bardzo we znaki, tylko dlatego, że brak absolutu pogrążył wszystkich w tak bardzo wielką za nim tęsknotę, tylko dlatego brano ową mętną wodę, podawaną przez filozofię romantyczna, prawiącą o pięknie, świętościach, absolucie itd., brano za czystą ciecz źródlaną i zapalczywie chciano nią gasić swe pragnienie. A tak samo, jak ta nowa epoka powstała wskutek zlania się, łączenia się i stapiania się nader licznych czynników i prądów umysłowych, kulturalnych, tak też może się ta epoka zrealizować i wypełnić, [s. 100] pozwoli się tym czynnikom wszystkim i prądom rozwinąć się i istotnie w całość zespolić. Romantyka jest więc tylko pierwszym przebłyskiem, pierwszym przeczuciem nowej epoki. Jest plonem poprzedzającej ją filozofii refleksji i oświecenia. Dalszy postęp musi na tym polegać, że owa filozofia refleksji na nowo się wzniesie 
na tle zbudzonej obecnie do życia estetycznej stronie umysłu ludzkiego. I to właśnie jest zadaniem obecnej filozofii. Więc prawdą pozostaje, że filozofia ma stanąć na stanowisku absolutu i wszechświat, wszechbyt pojmować z estetycznego punktu widzenia, ale na tym stanowisku musi ona pozwolić się na nowo rozwinąć ścisłym określeniom i rozróżnieniom rozumowym i napełnić je wyższym jeszcze znaczeniem. Tak więc wygląda rzecz pod względem konstrukcji historycznej, a wiemy już, jak ma wyglądać pod względem metodyczno-formalnym ${ }^{244}$. Ale nie trudno na tej podstawie wywnioskować, że teraz i dla zasady filozofii Heglowskiej, dla zasady, pod względem merytorycznym wyrażonej w słowach „absolut jest duchem”, a pod względem przedstawienia wyrażającej się $\mathrm{w}$ dialektyce, trzeba nowego sformułowania ${ }^{245}$.

\section{Wykład piętnasty z 3 marca 1905 roku}

[s. 101] Otóż takie nowe sformułowanie znajdujemy, a jego stosunek do dawniejszego, podobny jak stosunek nowej konstrukcji historycznej do dawniejszej. Jako równoznaczna z dawniejszą formułką: „absolut jest duchem” występuje teraz formułka: „Prawdziwy byt trzeba pojmować nie tylko jako substancję, lecz tak samo też jako podmiot" ${ }^{\prime 246}$. Albo: „Absolut jest zarówno substancją jak podmiotem" ${ }^{247}$. Oto nowy klucz do systemu Hegla w obecnej, estetycznej postaci. Ale ten klucz wymaga kilka słów objaśniających. Absolut w znaczeniu Schellinga, pojęty spinozystycznie jako tożsamość podmiotu i przedmiotu, jako indyferencja podmiotu i przedmiotu, nie może służyć za punkt wyjścia dla filozofii, która pragnie być ezoteryczna, która pragnie liczyć się z wymogami ścisłości rozumowej ${ }^{248}$. Albowiem tak pojęty absolut wykluczał wszelką świadomość, wszelką samowiedzę, był niezdolny sam do poznawania czegokolwiek i nie mógł być przez nikogo poznawany. "Jeżeli” powiada Hegel „wiek się oburzał, gdy mu kazano pojmować Boga jako jedną jedyną substancję, to podstawą tego oburzenia było instynktowne poczucie, że w takiej substancji samowiedza nie jest zawarta, lecz zniesiona" ${ }^{249}$. I w związku z tym zwraca się w sposób nam już znany przeciwko twierdzeniu, że w [s. 102] absolucie jest wszystko sobie równe, że jest on „noca, w której wszystkie krowy są czarne"250. Więc możność filozofii tym jest uwarunkowana, że absolut nie jest taką noca, zacierającą wszelkie różnice, lecz że w nim są różnice, że absolut sam w sobie się rozróżnia, że jest samorozróżnieniem, samoczynnościa, jednym słowem podmiotem. Podmiot bowiem, to jest samoczynna forma bytu. To znaczą słowa: „Według mego rozumienia rzeczy, które usprawiedliwić może dopiero przedstawienie samego systemu, wszystko zależy na tym, aby pojmować i wyrażać byt prawdziwy nie tylko jako substancję, lecz w równej mierze jako podmiot" ${ }^{\prime 251}$. Ta formułka znaczy więc, że absolutu 
nie można tak rozumieć, jak to czyniła romantyczna filozofia, lecz że trzeba to stanowisko skorygować filozofią Kanta i Fichtego. Znaczy ta formułka: Wszechświata nie można tylko wstawić i oprawić po prostu w ramy estetycznego pojmowania wszechrzeczy, lecz trzeba, aby refleksja wykończyła tło i otoczenie obrazu w takie ramy wstawionego. Formułka znaczy: Pogląd na świat musi wprawdzie, jak u Greków, polegać na poczuciu harmonii $\mathrm{z}$ wszechświatem, ale zarazem musi ten pogląd na świat zawierać w sobie poczucie siebie samego, swej własnej umysłowości, wyrobione filozofią refleksji i całą kulturą protestantyzmu. [s. 103] ([Odwołanie do] Hayma, 221252) Aby sobie uświadomić stosunek tego obecnie sformułowanego fundamentu systemu i obecnie skrystalizowanego systemu do jego pierwszej postaci, wywiezionej z Frankfurtu i następnie modyfikowanej, przypomnijmy sobie, że ów system pierwotny miał dwie zasadnicze myśli: Wszechświat jest całością piękną, harmonijna, zaokragglona, a zarazem duchem, gdyż jego istota jest duchem. Więc wszechświat podlega zarazem zasadniczemu procesowi ducha każdego, procesom refleksji, zastanowienia się, przeciwstawienia sobie siebie i poznania, że to ta rzecz jest identyczną z nim samym. To myśl jedna. A druga: Wszechświat, wszechbyt jest wszechżyciem, więc wszystkie jego części i członki pozostają w ciągłej od siebie zależności, ciągle na siebie wskazuja, w siebie przechodza, w siebie się rozwijaja jak w każdej istocie żyjącej, kształtując się w całość. Oto sens i uzasadnienie metody dialektycznej. - Otóż teraz rzecz ma się zasadniczo tak samo. Wszystko tylko dojrzało, przeszedłszy nieco wahań rozwojowych. Teraz system jak dojrzały mężczyzna, przedtem był młodzieńcem, jeszcze nie wyrobionym. [s. 104] ([Odwołanie do] Hayma, 221/2253) Przez pierwsze dwa i pół roku pobytu w Jenie system poddawał się Schellingowi, do niego się stosował, do niego się przytulał niejako; skutkiem tego strona estetyczna wyrobiła się znacznie i uwydatniła się bardziej. W następnych trzech latach odsunął się od Schellingianizmu; więc znowu wszedł bardziej w swe prawa czynnik logiczny, refleksyjny. W czasie pobytu $\mathrm{w}$ Jenie rozprawiał się na wszystkie boki z innymi poglądami filozoficznymi, toteż własny pogląd coraz bardziej się klarował, coraz wyraźniejsze przybierał rysy i kształty, a zarazem coraz bardziej uświadamiał sobie, jak dalece tkwi w swych podstawach w niemieckiej filozofii przełomu obu wieków, w Kancie, a zwłaszcza w Fichtem.

Stąd więc owa formułka, według której absolut jest duchem, ale będąc jako duch substancją jest też zarazem podmiotem. Stąd też teraz sprecyzowanie istoty i roli, jaką posiada w tym poglądzie dialektyka. Teraz dopiero dialektyka przedstawia się jako uformowana, prawidłowa metoda, którą nie tylko, jak przedtem się posługuje, ale której znaczenie podnosi i którą usiłuje jako czynnik zasadniczy systemu scharakteryzować. Wprawdzie postępował dialektycznie już w swym pierwszym zarysie; ale tam [s. 105] ([Odwołanie do] Hayma, 222/3254) owa forma 
dialektyczna była przytłumiona pomysłami, treścia, jako rusztowanie była zakryta wykonaniem gmachu. Prawo przeciwstawiania sobie siebie i znowu powrotu do siebie było środkiem, było służkiem, samo znaczenia dla siebie nie miało. Prawo tak mało miało znaczenia, że w Systemie moralności zupełnie zostało zepchnięte przez inne formalne strony widzenia. W owym Systemie sposób przedstawienia porusza się po Kantowskim przeciwieństwie wyobrażania i myślenia dyskursywnego, po schematach schellingiańskich rozstępywania i identyfikowania się. Ale obracanie się $w$ tych formach właśnie jeszcze bardziej zaostrzyło Heglowski zmysł formułowania i dlatego wracając teraz do swych pierwotnych form, ściślej je uwydatnił, a zarazem wyraźnie zaznaczył znaczenie tej formy. I rzecz ciekawa i znamienna. Tak jak pod względem zasady merytorycznej zbliżył się teraz do Fichtego, nazywając absolut „,substancją-podmiotem", tak też pod względem swej metody ku Fichtemu się bardziej teraz zwraca, przejmując od niego metodę tezy, antytezy i syntezy, metody, która wyłuszcza, jak absolut substancji staje się podmiotem [s. 106] ([Odwołanie do] Hayma, 223/4255), a potem znowu powraca z podmiotowości w swą substancjalność absolutną. Często posługuje się w tej mierze w Fenomenologii wyrazami, które wprost przypominają Fichtego. U Fichtego Jaźń absolutna przeciwstawiała sobie niejaźń, i poznawała tę niejako siebie samą. A u Hegla dowiadujemy się, że żywa substancja tylko o tyle jest bytem, będącym naprawdę podmiotem, o ile „jest ruchem stawania siebie samej, czyli pośrednictwem pomiędzy stawaniem się czymś innym a sobą samą"256. To pośrednictwo między stawaniem się czymś innym a sobą sama, pośrednictwo, na którym polega istota poznania absolutnego, „,nie jest niczym innym, jak poruszającą się samorówność, czyli jest refleksją w sobie samą, czynnikiem jaźni samobytnej, (des für sich seiendes Ich)"257. Metoda więc na tym będzie polegała, że punktem wyjścia będzie byt sam w sobie, das Ansichsein, po czym nastąpi das Anderssein, a na koniec das Fürsichsein ${ }^{258}$. Zatem metoda w zupełności identyczna z samym systemem. System bowiem w swym zasadniczym założeniu uczy rozwój absolutu jako ducha, a właśnie rozwój ducha polega na owych stadiach, na owym ruchu dialektycznym. Otóż tę metodę przeciwstawia Hegel wszelkim innym metodom w filozofii, metodom zapożyczanym ([Odwołanie do] Hayma, 224259) z matematyki, polegającym na określaniu, klasyfikowaniu, dedukowaniu; przeciwstawia ją też konstrukcjom schellingiańskim.

\section{Wykład szesnasty z 10 marca 1905 roku}

[s. 107] System skonstruowany według tej metodyki, która jest zarazem wyrazem istoty systemu, musiał się przedstawiać w oczach Hegla imponująco, istotnie też miał i ma w sobie coś imponującego, chociaż 
byśmy nie wiedzieć co przeciw niemu powiedzieli. Faktycznie imponował, mnóstwo umysłów wcale niepospolitych olśniewał, w swoją służbę brał. Hegel czuł się poniekąd nowym Arystotelesem, który usiłował całość świata $\mathrm{w}$ jeden system zaokrąglony ująć ${ }^{260}$. I może być, że dlatego właśnie $\mathrm{z}$ takim zamiłowaniem zatrzymywał się nieraz $\mathrm{w}$ myślach nad ową epoką przejściową w kulturze świata starożytnego, kiedy to właśnie dawny świat klasyczny zarysował się i pękał, kiedy byt polityczny Greków z wolnego i samodzielnego stał się zależnym od panowania królów macedońskich; wszak i jego ojczyzna straciła byt niezawisły pod razami oręża napoleońskiego. Ale to nie jedyne podobieństwo. Wszak przed upadkiem rozkwit życia estetycznego u Greków, sztuki na wyżynach; a filozoficznym niejako wyrazem tego stanu filozofia Platona, niemniej poety jak filozofa. A w Niemczech również rozkwit poezji niebywały, i tak samo poezja [s. 108] ([Odwołanie do] Hayma, 225/6 ${ }^{261}$ ) znalazła swój odpowiednik filozoficzny w filozofii romantycznej, zwłaszcza Schellinga, filozofa poetyzującego. A jak po Platonie trzeźwy przyszedł Arystoteles, organizując całość wiedzy według pewnych zasadniczych pojęć materii, formy, przyczyny sprawczej i celowej, bytu potencjalnego i aktualnego, tak teraz przychodzi Hegel i podobną organizującą pracę pragnie przeprowadzić. Analogię tę często zauważano, i nie jest rzeczą wykluczona, że sam Hegel chętnie o niej myślał. Ale niech z tym będzie jakkolwiek bądź, faktem pozostaje niezaprzeczonym, że w owych właśnie czasach rozczytywał się pilnie w Arystotelesie i że wskutek tego pewne rysy filozofii tegoż sobie przyswoił, tak jak przedtem przeważnie (w Systemie moralności) pozostawał pod wpływem Platona ${ }^{262}$. Zasadniczym takim rysem jest właśnie pojęcie celu, teleologia Arystotelesa. Cała przyroda jest łańcuchem celowych zdarzeń i faktów. Wszystko co jest, jest tym, czym jest dzięki swej istocie, swej formie, swej idei, i takie pełne wyrażenie idei, formy, istoty jest celem, ku któremu w przyrodzie wszystko dąży. Nasienie, jajko, jest [s. 109] ([Odwołanie do] Hayma, $226^{263}$ ) czymś, co ma swój cel w zarodku, zarodek w dziecku, dziecko w młodzieńcu, młodzieniec w dojrzałym mężczyźnie. I tak wszędzie. Cała przyroda takim łańcuchem celowego rozwoju. Otóż coś całkiem analogicznego u Hegla mamy. I u niego świat cały w pochodzie rozwojowym się znajduje; a celem tej także pełne urzeczywistnienie idei, ducha, absolutu w coraz wyższych formach konkretnego bytu, aż nareszcie absolut sam do siebie powraca, w swój byt dla siebie, wychodząc z bytu w sobie przez byt odmienny. (Aus dem Ansichsein durch Anderesein in Fürsichsein); "Absolut jest stawaniem się siebie samego, jest kołem, suponującym swój koniec jako swój cel i mającym swój koniec jako swój początek, i będącym rzeczywistym tylko przez to, że się to koło przeprowadza i że ono ma swój koniec" ${ }^{264}$. Niejednokrotnie posługuje się całkiem świadomie zwrotami z Arystotelesa, zaczerpniętymi albo do niego upodobnionymi; niejednokrotnie wprost utożsamia pojęcie pod- 
miotu z pojęciem celu. Jeżeli Arystoteles nazwał przyrodę działaniem celowym, Hegel powiada, że „rozum jest działaniem celowym”265. Cel jest tym bezpośrednim, nieporuszonym, spoczywającym, „które samo porusza [s. 110], a wskutek tego jest podmiotem"266. ([Odwołanie do] Hayma, 228/9267) To więc przypomina nam Arystotelesa, według którego to proton kinounon, absolut, Bóg, będąc zarazem celem wszechbytu, samo spoczywa, a wszystko inne w ruch wprawia, tak jak w ogóle cel, który mamy na myśli, nas ku sobie porusza, sam będąc nieporuszanym.

To na razie dla ogólnej charakterystyki. A nie może już być po tym wszystkim żadnej wattpliwości o tym, o co właściwie chodzi Heglowi. Z powyższego streszczenia przedmowy Fenomenologii wynika jasno, że pragnie on dać system filozoficzny, pogląd na świat ściśle naukowy, że wypowiedział wojnę fantasmagoriom, że żąda dla filozofii wyrobionej i jej właściwej metody. Piękno, sztuka, harmonia - dobrze, to być winno, to $\mathrm{w}$ świecie jest; ale jest też rozum, ład, układ, porządek. Uniesienia romantyków muszą być sprowadzone do właściwej miary refleksją rozumu; czynniki kulturalne, umysłowe, które dotychczas stanowiły trwałe zdobycze, mają być zlane $\mathrm{w}$ jedną całość za pomocą metody naukowej, metody postępującej krok za krokiem naprzód, a nie ulatującej pod niebiosa, pijanej własną frazeologią. - Więc piękno i prawda naukowa, uczucie i rozum mają zlać się w jedno. [s. 111] ([odwołanie do] Hayma, $229,30 / 31^{268}$ ) To ideał Hegla, to idealna meta jego filozofii. I niezawodnie ideał nam sympatyczny, meta, ku której wszyscy chętnie z nim w drogę ruszamy. Nam się to wydaje poniekąd całkiem jasne, samo przez się zrozumiałe, że trzeba kulturę rozumu trzeźwego jakoś zjednoczyć z kulturą estetyczną. Może właśnie dlatego nam to tak jasne, że Hegel i jego szkoła nam to ciągle mówili. Ale inna kwestia, czy się Heglowi to udało przeprowadzić, inna kwestia, o ile on w swym systemie potrafił istotnie zjednoczyć te dwa czynniki, estetycznej kultury świata starożytnego i romantyki z rozumowymi czynnikami wieku oświecenia i refleksji filozoficznej? Różnie różni sądzą. Wiadomo, iż był czas, że wielu ślepo Heglowi wierzyło - i u nas; inni odwrócili się od niego nie tracąc szacunku dla jego ducha i dzieła; jeszcze inni, jak Schopenhauer, z błotem go zmieszali i nie tylko jego filozofii, ale i jego charakterowi wszelkiej odmówili wartości ${ }^{269}$. Gdybym teraz wypowiedział swe zdanie, nie potrafiłbym go uzasadnić. Dlatego poznajmy naprzód ten cały system i jego przeprowadzenie, a potem będziemy się starali wydać sąd o tym systemie. Musimy więc przejść i fenomenologię, i logikę, i encyklopedię filozofii, i filozofię prawa, i filozofię religii, sztuki, historii. [s. 112] ([Odwołanie do] Hayma, XI, 233270) Czym jest, czym chce być Fenomenologia ducha? Po prostu usprawiedliwieniem stanowiska filozofii heglowskiej, usprawiedliwieniem stanowiska absolutnego ducha, absolutnej wiedzy, absolutnego poznawania. Już wobec uczniów czuł tę potrzebę, a tym bardziej, skoro od romantyzmu nawrócił się na pojmowanie bardziej naukowe filozo- 
fii. Wiedza o duchu absolutnym, wiedza absolutna ma być celem, do którego prowadzi fenomenologia. Od najniższego stopnia wiedzy aż do owego najwyższego trzeba kroczyć. Trzeba wszystkie te stopnie wiedzy kolejno przejść, a niedorzecznie poczyna sobie entuzjazm, „który bezpośrednio, jakby z pistoletu, zaczyna od wiedzy absolutnej, a wszelkie inne stanowiska już tym samym uważa za załatwione, że się zupełnie o nie nie troszczy"271. Możemy teraz zrozumieć tytuł dzieła ([Odwołanie do] K. Fischera, II, 230272 ). Stopniowo od najniższej wiedzy duch się wznosi aż do absolutnej wiedzy. To stopniowe wznoszenie się ducha wyprzedza wiedzę absolutną i do niej prowadzi. Te stopnie, to kolejno coraz wyższe stanowiska, które zajmuje duch. Więc stosownie do tych stopni ducha przedstawiają się różnie, kolejno z coraz wyższego punktu widzenia, wszelkie przedmioty wiedzy; filozofowi zaś przedstawiają się [s. 113] stopniowo właśnie owe różne, coraz wyższe punkty widzenia, zjawiają mu się. Więc te coraz wyższe punkty widzenia, te coraz wyższe stanowiska, stopnie wiedzy są zjawiskami, które bada filozof, a nauka o tych stopniach to fenomenologia ducha, nauka o zjawiającym się kolejno, powstającym, rozwijającym się poznawaniu. Więc fenomenologia ma zadanie zarazem naukowe i praktyczno-pedagogiczne.

\section{Wykład siedemnasty z 17 marca 1905 roku}

Ma uzasadniać stanowisko wiedzy absolutnej, a zarazem adeptów filozofii, tych, którzy szczerze pragną ją posiąść, do niej doprowadzić. Zadanie to spełnia, krocząc równocześnie różnymi drogami. Podaje rozbiór psychologiczny świadomości przedfilozoficznej w różnych jej stadiach. Zawiera krytykę innych stanowisk filozoficznych; wciela w siebie rozważania historyczne, a to zarówno z dziedziny historii filozofii, jak z dziedziny historii powszechnej. Więc ma charakter pedagogiczny, psychologiczny, krytyczny, historyczny. To wszystko nie jedno obok drugiego, ściśle i czysto odgraniczone, lecz to wszystko razem, w jedno zlane i w jedno stopione. $-\mathrm{Z}$ tych wszystkich dróg i sposobów dwie wybijają się na plan pierwszy: Dowód transcendentalno-psychologiczny i dowód historyczny. Dlaczego transcendentalno-psychologiczny? [s. 114] ([Odwołania do] Hayma, 235, i Fischera ${ }^{273}$ ) O dowodzie transcendentalno-psychologicznym sam Hegel powiada, że jest właściwym jądrem fenomenologii, filarem, dźwigającym całość gmachu; wszystko inne tylko jakby rozprowadzeniem tego dowodu ${ }^{274}$. Takim rozprowadzeniem po części także ten dowód drugi, historyczny ${ }^{275}$. - Otóż co znaczy i na czym polega ów dowód transcendentalno-psychologiczny? Transcendentalny to $\mathrm{w}$ znaczeniu kantowskim. U niego analiza funkcji poznawczych $\mathrm{w}$ kierunku zbadania wiedzy apriorycznej nazywa się filozofią transcendentalną. Zawiera się w krytyce czystego rozumu, 
praktycznego rozumu i władzy sądzenia, władzy oceny ${ }^{276}$. To samo miał na myśli Fichte w swej Wissenschaftslehre, gdy chodziło mu o wskazanie prawa rozumu ludzkiego do wiedzy apriorycznej; a dowodził tego prawa, wyłuszczając początek i powstawanie naszego przedstawiania sobie przedmiotó $w^{277}$. Podobnie i Schelling sobie poczynał, nazywając tego rodzaju wywody „pragmatyczną historią naszej świadomości” ${ }^{278}$. Do takiego pojęcia transcendentalnej filozofii nawiązał Hegel. Uogólniając sformułowanie Schellinga, powiada, że trzeba „jednostkę ogólną ducha świadomego siebie rozważać, jak się tworzy"279. Fenomenologia [s. 115] ([Odwołanie do] Hayma, 236 $\left.{ }^{280}\right]$ opowiada tedy historię ducha, świadomości, którą ta świadomość sama przeszła, jest „«nauką», «wiedzą» o doświadczeniu, które przechodzi świadomość" 281 . Więc ta fizjologia opowiada nam przejścia istoty żyjącej od formy zarodka do pełno rozwiniętych form, tak fenomenologia opowiada nam przejścia świadomości od jej stanu pierwotnego, embrionalnego aż do zupełnej dojrzałości, do stanu najwyższego. Można ja, słowami Hegla, uważać jako „drogę duszy, przebywającej szereg swych różnych postaci jako wynikających z jej istoty, stacji, aby wznieść się do stanu duchowości"282, do stanu, w którym osiągnąć może wiedzę absolutną. Ale tu nasuwają się różne wątpliwości ([Odwołanie do] Fischera, II. 296 ff²83). Czy w ogóle możebna jest taka fenomenologia, przedstawiająca nam drogę, podróż świadomości, tym sposobem, że sama tę drogę przebywa? Czy to nie jest zadanie niedostępne dla ludzkiej władzy poznawczej? Czy w ogóle wiedza jest możliwa, a zwłaszcza taka, o jaką chodzi fenomenologii? Wszak władza poznawcza albo narzędziem, albo środowiskiem. Narzędziem, opracowującym, obrabiającym przedmioty poznania, a tym samym zmieniającym je; środowiskiem, w którym nam się przedmioty przedstawiaja, zjawiaja, ale zarazem ulegają zmianom stosownie do praw tego środowiska. A tak w jednym, jak w drugim wypadku nigdy przedmiotów nie poznajemy [s. 116] ([Odwołanie do] Fischera, II. 297284), jakimi są. To więc prowadzi do sceptycyzmu. Ale właśnie fenomenologia przezwycięża ten sceptycyzm tym sposobem, że wchłania go w siebie jako jedną ze swych istotnych części, jako zasadniczy szczebel tej drabiny, którą sama jest, prowadząc do wyżyn absolutnej wiedzy. Mianowicie zarówno pojmowanie władzy poznawczej jako narzędzia, jak jako środowiska, pozostającego w pewnym stosunku do przedmiotów, jest mylne; opiera się bowiem na przeciwstawieniu myślenia i rzeczy, podmiotu i przedmiotu, obiektu i świadomości, poznawania i absolutu. W takich warunkach wiedza, a z nią i fenomenologia wydaje się czymś niemożebnym. Ale założenia te mylne; rozpryskują się wobec faktu wiedzy, zjawiającej się zrazu w słabych przebłyskach i coraz pełniej się rozwijającej, kroczącej od błędów i pomyłek do prawdy. Albowiem leży to w istocie świadomości, że ujmując pewną prawdę, przyswajając ją sobie i przenikając ją tym samym poznaje jej nicość i prawdę tę znowu porzuca. $Z$ tej więc 
strony droga i praca świadomości przedstawia się wyłącznie jako droga ciągłego wątpienia, a nawet zwątpienia, jeżeli wynikiem wszelkich wyników ma być nicość tych wszystkich wyników. Fenomenologia, okazując nam tę drogę [s. 117] ([Wykład prowadzony dalej za] Fischerem, II. 298/9285) jest tym samym „sceptycyzmem, dotyczącym całego zakresu zjawiającej się nam wiedzy"286. Ale ten sceptycyzm wcale nie prowadzi do nihilizmu, na którym uważamy prawdę za rzecz niedoścignioną bezwzględnie, lecz dotyczy zawsze tylko pewnej, określonej prawdy, którą po jej przyswojeniu sobie porzucamy, ale nie, aby popaść w nicość, lecz aby wznieść się do dalszej nowej prawdy. Porzucenie każdej określonej prawdy jest zarazem nabyciem nowej określonej prawdy. Więc nie nihilizm, lecz negacja. Tak o tym sam Hegel mówi: „Sceptycyzm, kończący się abstrakcją nicości, czyli próżni, nie może stąd dalej kroczyć, lecz musi czekać, czy i co nowego będzie mu dane, aby je znowu cisnął w przepaść tej samej próżni. Jeżeli jednak każdy wynik pojmujemy, tak jak jest w istocie, jako określoną negację, tym samym dajemy początek formie nowej, a w negacji leży przejście, na tle którego sam z siebie wynika dalszy pochód przez kompletny szereg postaci"287. - Ale skoro ma być ten szereg kompletnym, musi być zamkniętym w sobie, musi mieć koniec, cel, kres. Póki tego kresu nie osiagnie, świadomość rwie się ciągle dalej, z żywiołową siłą coraz dalej prze i pędzi. Dopiero wtedy zadowolona i zaspokojona staje, gdy już [s. 118] ([Wykład prowadzony za] K. Fischerem, II, 299/300288] ma, do czego dążyła. Jaki to cel, już wiemy. Owe kolejne postacie świadomości, owe kolejne stadia wiedzy były jakby tyloma odsłonkami, które stopniowo coraz bardziej przejrzystymi się stawały, aż nareszcie ostatnia zasłona spadła, tak iż w całym świetle, bezpośrednio okazuje się to, co leżało na dnie wszelkich tych postaci świadomości i kolejno je do bytu powoływało. A tym, co leżało na dnie tych wszystkich postaci świadomości, była świadomość sama, wiedza sama. Z chwilą zaś, gdy świadomość dotknie się samej świadomości, gdy wiedza dotrze do samej wiedzy, wiedza jako taka, absolutna, bezwzględna, wtedy też zadanie spełnione: przedmiot i pojęcie [są] wtedy identyczne; przedmiot równy [jest] pojęciu; jedno drugiemu w zupełności odpowiada. To też jest zarazem kres wiedzy i kres sceptycyzmu, albowiem ów dualizm pojęcia i przedmiotu, myśli i rzeczy, dający początek wszelkiej wątpliwości, tutaj znika i zupełnie został zniesiony. Słowami Hegla: „Cel jest czymś dla wiedzy równie koniecznym jak szereg kolejnych stopni; cel zaś jest tym, gdzie świadomość już nie ma potrzeby wyjścia poza siebie, gdzie sama się znajduje, gdzie pojęcie odpowiada przedmiotowi, a przedmiot pojęciu. Pochód ku temu celowi jest nieprzeparty i na żadnej wcześniejszej stacji nie ma zadowolenia. [...] Świadomość zaś jest dla siebie samej swym pojecciem" 289 . 


\section{Wykład osiemnasty z 24 marca 1905 roku}

[s. 119] ([Wykład prowadzony za] K. Fischerem, 300 ff..290)

Cały pochód świadomości od najniższego stopnia aż do najwyższego uskutecznia się na tej podstawie, że świadomość ustawicznie i nieustannie doświadcza, iż przedmiot poznania w rzeczywistości nie jest takim, jakim go dotąd poznawała, że różni się od pojęcia, które sobie o nim utworzyła. Przedmiot i pojęcie oto dwa czynniki, których porównywanie tworzy temat działania świadomości; pojęcie jest miara, przykładaną do przedmiotu, a przedmiot jest tym, co porównujemy pojęciem, przekonując się ciągle, że pojęcie mu nie odpowiada. - Otóż między świadomością a przedmiotem dwojaki zachodzi stosunek: 1. Odnosi się do przedmiotu swego, 2. Różni się od przedmiotu swego. Na odnoszeniu się świadomości do przedmiotu polega wiedza; przedmiot, do którego się świadomość odnosi, to jest przedmiot wiedzy; - nadto jednak przedmiot poza tym, że jest przedmiotem wiedzy (der gewusste Gegenstand) jest też czymś od świadomości różnym, jest czymś dla siebie, jest bytem w sobie. - Więc dwa momenty trzeba w przedmiocie odróżnić: 1 . Że bywa odnoszony do świadomości, 2. To, że bywa odróżniony od świadomości. [s. 120] - A ponieważ przedmiot i świadomość są nawzajem czymś innym, przeto też przedmiot, o ile jest wzięty w odniesieniu do świadomości, może być uważany za będący dla czegoś innego, jego odnoszenie się do świadomości można nazwać jego „byciem dla czegoś innego", jego „innobytem”291. O ile zaś jest wzięty nie w odniesieniu do świadomości można nazwać przedmiot "będącym dla siebie samego", można w tym znaczeniu mówić o jego "samobycie" (sein Füreinandersein, sein Ansichselbstsein)292. To są dystynkcje i terminy, wzięte z Fichtego ${ }^{293}$. - Więc możemy teraz także powiedzieć, że wszelki postęp świadomości polega na niezgodności między przedmiotem a jego pojęciem, między sposobem, jakim przedmiotem jest dla świadomości, a sposobem, jakim jest dla siebie, między jego „innobytem” a "samobytem”294. Na tym ustawicznym dopasowywaniu pojęcia do przedmiotu polega to, co nazywamy doświadczeniem; a doświadczenie się tworzy i zdobywa, zaniechając dotychczasowe poglądy, a zdobywając sobie nowe. Zupełnie więc jak $\mathrm{w}$ dialogu filozoficznym, gdzie pod wpływem przytaczanych $\mathrm{z}$ obu stron argumentów obie strony swe poglądy [s. 121] ([Wykład dalej za] K. Fischerem, I. $303^{295}$ ) zmieniaja formują i tym sposobem nabywają coraz to nowej wiedzy. Stąd to pochodzi, że Hegel pochód świadomości od najniższego do najwyższego szczebla wiedzy nazwał dialektyka, od dialegesthai, nazwał ruchem dialektycznym. Dosłownie: „Ten ruch dialektyczny, który wykonuje świadomość na sobie samej, zarówno na swej wiedzy, jak na swym przedmiocie, o ile jej się stąd wyłania 
nowy prawdziwy przedmiot, jest we właściwym znaczeniu tym, co nazywa się doświadczeniem"296. - Zobaczmy teraz, jakie to są owe szczeble, przez które świadomość wznosi się coraz wyżej, aż do swego celu? Wynikają one z następującego rozważania: Świadomość odnosi się do swych przedmiotów, a zarazem się od nich różni. Więc mamy dwa pierwsze szczeble: Świadomość czegoś innego, czyli jednym słowem świadomość, i świadomość sama w sobie, czyli samowiedza; można te dwa szczeble też przeciwstawić jako wiedza przedmiotów i samowiedza. [s. 122] ([Wykład dalej za] K. Fischerem, I, 305297) Wiedza o przedmiotach i wiedza o sobie, czyli świadomość i samowiedza mają się jak przedmiot i podmiot do siebie, jak obiekt i subiekt; ich jedność jest rozumem. Więc rozum stanowi trzeci szczebel świadomości, świadomość rozumowa, Vernunftbewusstsein. Wszelako wiemy już, że Hegel kładzie nacisk na podmiotową naturę absolutu, więc też rozum, jako identyczność podmiotu i przedmiotu musi mieć ten podmiotowy charakter, nie śmie być tylko substancja lecz podmiotem; a rozum jako podmiot jest rozumem świadomym siebie, rozumem samowiednym. Taki zaś rozum nazywa się duchem. Więc rozważywszy rozum w ogóle, trzeba go też rozważyć jako ducha. Objawieniem ducha zaś jest porządek świata, a najwyższym znowu szczeblem tego porządku wszechświatowego jest idea Boga w świecie, więc religia, osiągająca swe dokończenie w prawdziwym poznaniu Boga. Prawdziwe zaś poznanie Boga jest wiedzą absolutną. Oto zarys architektoniki fenomenologii, który się zatem według Hegla przedstawia tak: A. Świadomość. B. Samowiedza, C. Rozum. Rozum zaś jest rozważany jako AA. Wzięty dla siebie, jako identyczność podmiotu i przedmiotu [s. 123] ([Odwołanie bezpośrednie do] K. Fischera, II, 308-9298), BB. Jako duch, CC. Jako religia, DD. Jako wiedza absolutna. Każdy z tych działów, na który się tym sposobem rozpada fenomenologia, znowu na trzy części się dzieli. Wymienię pokrótce i wyjaśnię: Świadomość obejmuje trzy szczeble: I. Pewność zmysłowa to i mniemanie (Die sinnliche Gewissheit, das Dieses und das Meinen $)^{299}$. Szczebel bezpośredniego odbierania wrażeń zmysłowych. Wiedza bezpośrednia występuje z całą pewnościa, odnosi się do konkretów szczegółowych. Ale przy bliższym zbadaniu tak nie jest. Każdy przedmiot, będąc tym lub tamtym, jest zawsze tu i teraz. Ale tu i teraz ciągle jest czymś innym. Więc wszelkie tu i teraz, wszelkie to lub tamto ma charakter ogólny! Chcąc go przed tą ogólnością obronić, trzeba go wskazać, wymienić go nie można. A wskazać, to znaczy złączyć go z jakimś podmiotem wskazującym. Więc wiedza, pozornie najbardziej przedmiotowa, konkretna, staje się podmiotowa. Co więc zdawało się czymś prostym, przedstawia się jako coś bardzo złożonego, jako przedmiot posiadający liczne określenia, a każde jest o charakterze ogólnym. Świadomość teraz więc bierze przedmiot nie jakim się przedstawiał zrazu, lecz jakim jest w rzeczywistości, tj. spo- 
strzega go. (Es nimmt ihn, wie er in Wahrheit ist, es verhält sich zu seinem Gegenstande wahrnehmend) ([Odwołanie bezpośrednie do] K. Fischera, II, $\left.309^{300}\right)$.

\section{Wykład dziewiętnasty z 31 marca 1905 roku}

[s. 124] ([Wykład z odwołaniami do] Hayma, 236/7/8 ${ }^{301}$ ) I w ten sposób idzie cała rzecz dalej. Próba podana wystarczy. Ale nie cała treść fenomenologii $\mathrm{w}$ tym duchu trzymana, lecz $\mathrm{w}$ owe dialektyczne rozumowania o charakterze transcendentalno-psychologicznym wsuwa się na każdym kroku konstrukcja historyczna najwyższego stanowiska poznawczego, stanowiska wiedzy absolutnej. Można by się dziwić, skąd to się bierze, jakim prawem to się dzieje. Ale odpowiedź prosta i w głowie Hegla żadnej nie ulegała wątpliwości. On po prostu rozprawia o świadomości, o duchu w ogóle, i identyfikuje ten duch w ogóle z ogólnym duchem czasu, ogólnym duchem ludzkości, z jego kolejnymi objawami, z dziejami. Więc transcendentalno-psychologiczny rozwój świadomości identyczny z rozwojem duchowym świata. Cała ludzkość przechodzi te same koleje, które przechodzi jednostka, wznosząc się od pewności zmysłowej do wiedzy absolutnej. Słowami Hegla: „Cel, wiedza absolutna, czyli duch poznający siebie jako ducha ma jako swą drogę pamięć duchów, jakimi są same w sobie, i jakimi będąc, tworzą organizację swego królestwa. Przechowaniem tej organizacji pod względem jej swobodnego, w formie przypadkowości zjawiającego [s. 125] ([Odwołanie do] Hayma, 239,240302) się bytu, są dzieje; pod względem zaś organizacji ujętej w pojęciu jest tym przechowaniem nauka zjawiającej się wiedzy"303. (Häckel - prawo biogenetyczne ${ }^{304}$ ). - Więc jakiś czas pierwsze rozdziały fenomenologii czytamy zupełnie jako rozprawę psychologiczno-epistemologiczną. Ale zaledwie dotarliśmy do rozdziału o samowiedzy, spotykamy się z charakterystyką narodów wschodnich, ich samowiedzy manifestującej się $\mathrm{w}$ despotyzmie, po czym następuje charakterystyka stoicyzmu i sceptycyzmu. Następnie znowu ślady rozwoju dziejowego nieco się zacierają. Ale niebawem wyłania się jakby we mgle, a potem coraz wyraźniej obraz etyki średniowiecza, jej ascezy, zakonnego życia itp. Potem znowu spotykamy się z obywatelskim duchem Ateńczyków. Poznajemy nawet konkretne postacie: Kreona, Antygonę, Ismenę; potem mowa o Rzymianach, ich poczuciu państwowym i prawnym, ich panowaniu nad światem. Ale nie tkwimy wciąż w starożytności. Mamy też obraz życia dworaków Ludwika XIV i XV; poznajemy encyklopedystów i znowu konkretne postacie z ich dzieł i pism. Potem o wieku oświecenia w Niemczech mowa; walk z ortodoksją kościelną; [s. 126] ([Odwołanie do] Hayma, 239 ${ }^{305}$ ) walka z wszystkim, co przypomina nadprzyrodzoność. I znowu zmiana scenerii. Rozdział pod napisem 
„Bezwzględna swoboda i strach" prawi o rewolucji francuskiej, o krwawych walkach, o gilotynie, Robespierze i jego sługach. Potem droga dalej prowadzi do filozofii Kanta i Fichtego, a przez nie jako też przez niemieckie piśmiennictwo i romantykę do szkicu dziejowego wielkich religii światowych, tajemnic wiary chrześcijańskiej do celu, do najwyższego stanowiska wiedzy absolutnej. „Historia, pojęta i zrozumiana, oto pamięć i zarazem cmentarzysko ducha absolutnego, oto prawdziwość, rzeczywistość i pewność jego panowania, bez którego byłby bezdusznym samotnikiem; tylko (cytat) z czary tego duchów świata pieni mu się nieskończoność" ${ }^{306}$. Oto końcowe wyrazy fenomenologii. Tak więc historia i psychologia w jedno splecione, wspólnie mają dźwigać gmach, wspólnie mają być logicznym jego fundamentem, podstawą twierdzeń. A w tym właśnie tkwi już pierworodny grzech tej całej fenomenologii. Psychologiczna analiza wymaga dotarcia do form najprostszych, pierwiastkowych, elementarnych. W dziejach zaś wszystkie [s. 127] ([Odwołanie do] Hayma, 240 307) objawy ducha i duszy i świadomości występują w formie konkretnej, zależnej od tysiącznych okoliczności. W dziejach nie ma owych abstrakcji psychologicznych, tak jak w przyrodzie nie ma abstrakcji, którymi operuje fizyka. To więc jedna wątpliwość; albowiem trudno $\mathrm{w}$ jedno spoić tak różnorodne sposoby patrzenia na świat. Ale może każdy z osobna jest trafny i cenny? Może każdy z osobna uzasadnia, i chociaż nie w zespoleniu, lecz przy wzajemnym wspieraniu się przekonują nas? - Otóż co do dowodu transcendentalno-psychologicznego nie trzeba być wielkim filozofem, aby spostrzec, jak lekkomyślną tu się prowadzi grę słowami. Przypominam tylko twierdzenie o tym, że pewność zmysłowa, zrazu wydająca się odnosić do rzeczy całkiem konkretnej, szczegółowej, prostej, przemienia się w coś ogólnego, albowiem każde "tu" i „teraz" jest czymś ogólnym!!! A co do historycznej strony dowodu, także nie trzeba być wielkim historykiem, aby odczuwać pewne wątpliwości. Na przykład nie ma ciągłego toku dziejów i odpowiadania. Są fragmenty, kawałki, disjecta membra. Wybór dowolny zupełnie. Co się właśnie za epoka lub postać nasuwa, ta bywa rozpatrywana i charakteryzowana. Można czasem stwierdzić, że [s. 128] ([Odwołanie do] Hayma, 242/3/4 ${ }^{308}$ ) właśnie lektura w danej chwili wpłynęła na wysunięcie tej lub owej postaci. A takie wysunięcie oznacza upatrywanie w tej epoce lub owej postaci reprezentanta koniecznego szczebla w rozwoju świadomości. Jeżeli na przykład takiej godności dostępuje rewolucja francuska, to czemuż nie walka religijna za Karola I w Anglii albo okres cały reformacyjny? Do tego wszystkiego razi jeszcze w najwyższym stopniu ta niesłychana dowolność chronologiczna. Raz pochód dziejowy chronologiczny jest tą nicią, której trzyma się rozwój dialektyczny; raz znowu na odwrót, rozwój dialektyczny przepisuje następstwo faktów i rozważań historycznych. Co dziejowo należy razem, rozerwane, co psychologicznie od siebie dalekie, zsunięte ze względu na rozwój 
dziejowy. Więc historia zbałamucona i zupełnie zdezorganizowana dialektyką świadomości, a psychologiczna analiza dialektyki świadomości pobałamucona względami historycznymi. Zamiast żeby się wspierać, te dwa względy wzajemnie sobie przeszkadzają. Tak więc nie możemy zaoszczędzić fenomenologii szeregu ciężkich zarzutów, a one dotyczą wraz z treścią także i stylu dzieła. Trudno sobie coś cięższego wyobrazić.

Koniec półrocza zimowego 1904/5

[Wkładka po str. 128]

W razie więcej czasu należy tu jeszcze wsunąć bliższe krytyczne wywody Hayma o fenomenologii ducha, str. 244-260 ${ }^{309}$. Obecnie, na przejściu z półrocza zimowego do letniego 1904/5, zaraz przechodzę do dalszej biografii: opuszczenie Jeny, przeniesienie do Bambergu etc. Haym 260 nn. ${ }^{310}$ K. Fischer, I. 65 nn ${ }^{311}$. 


\section{Radosław Kuliniak, Dorota Leszczyna, Mariusz Pandura, Łukasz Ratajczak}

\section{Komentarz do cyklu zimowego wykładów o filozofii Hegla}

1 Zob. A. Schopenhauer, Die beiden Grundprobleme der Ethik, behandelt in zwei akademischen Preisschriften, Zweite, verbesserte und vermehrte Auflage, Leipzig 1860, „Vorrede zur ersten Auflage”, s. XX.

2 Zob. ibidem, s. XXI.

3 Zob. ibidem, s. XXII.

4 Pogląd Gustava Theodora Fechnera pochodzi z opublikowanej w 1861 roku pracy tego niemieckiego filozofa, zatytułowanej Über die Seelenfrage: „Die Hegelsche Philosophie ist in gewissem Sinne die Kunst, ein richtiges Schließen zu verlernen" (zob. G. Th. Fechner, Ueber die Seelenfrage. Ein Gang durch die sichtbare Welt, um die unsichtbare zu finden, Leipzig 1861, s. 45). Kilkanaście lat później Twardowski poprzedził wstępem polskie tłumaczenie tego tekstu (zob. K. Twardowski, Gustaw Teodor Fechner, 2. Wstęp do polskiego przekładu "O zagadnieniu duszy" (1921), w: idem, Rozprawy $i$ artykuły filozoficzne, Lwów 1927, s. 260-265). Bardzo możliwe jednak, że pogląd Fechnera został zaczerpnięty za pośrednictwem jednego z wydań szeroko znanej pracy Friedricha Ueberwega, gdzie z wydania trzeciego (zob. F. Ueberweg, Grundriss der Geschichte der Philosophie der Neuzeit von dem Aufblühen der Alterthumsstudien bis auf die Gegenwart, 3. verbesserte und ergänzte Aufl., (F. Ueberweg, Grundriss der Geschichte der Philosophie 3) Berlin 1872, s. 344) cytowane powyżej zdanie było powtarzane niemal dosłownie, także w wersjach książki opracowanych przez Maxa Heinzego (zob. Friedrich Ueberwegs Grundriss der Geschichte der Philosophie der Neuzeit, s. 490). Wiele lat później Twardowski napisał też „Wstęp” do tłumaczenia innej książki Fechnera i wyrażał się bardzo pochlebnie o niemieckim filozofie, uznając go za ,,jednego z najwybitniejszych myślicieli i badaczy wieku XIX" (zob. K. Twardowski, Gustaw Teodor Fechner, 1. Wstęp do polskiego przekładu Ksiażeczki o życiu pośmiertnem (1907), w: idem, Rozprawy i artykuty filozoficzne, s. 260).

5 R. Haym, Hegel und seine Zeit. Vorlesungen über Entstehung und Entwickelung, Wesen und Werth der Hegel'schen Philosophie, Berlin 1857, „Erste Vorlesung. Einleitung", s. 4.

${ }_{6}$ Niezwykle pomocny okazał się przy rozpoznaniu przez Twardowskiego recepcji XVIII i XIX-wiecznej filozofii niemieckiej w filozofii polskiej, zwłaszcza Hegla, Systematyczny wykład Logiki, czyli nauka dochodzenia i poznania prawdy, przez Henryka Struve, „II. Rys historyi i literatury logiki. \$21. Piąty okres filozofii w Polsce. Zwolennicy i przeciwnicy Hegla", s. 219-283. Zdaniem Twardowskiego, wykład dany przez Struvego jest nie tylko wystarczający, lecz jedyny z możliwych. W okresie międzywojennym stał się niezstąpionym podręcznikiem z historii logiki.

7 Zob. ibidem, „4. Józef Kremer”, s. 231-238, „5. Bronisław Trentowski”, s. 239-267, „6. Karol Libelt”, s. 268-272, „7. August Cieszkowski”, s. 273-276, „8. Józef Gołuchowski", s. 277-283. 
8 Zob. ibidem.

$9 \quad$ K. Rosenkranz, Georg Wilhelm Friedrich Hegel's Leben, Berlin 1844.

10 Twardowski, deklarując swoje odwołanie do wykładów Hayma, nie zrezygnował jednak z oparcia własnego wykładu na trudnych rozważaniach Rosenkranza. Uzupełniał go konsekwentnie o rozważania Hayma, Fischera i Rosenkranza tudzież obecne są, lecz rzadko, uwagi Windelbanda. Wykład Hayma wydawał się Twardowskiemu w chwili rozpoczynia pisania własnych rozważań nad Heglem najbardziej przystępy i przejrzysty w swej treści. Poza tym łączył historię życia Hegla z wykładem systematycznym jego filozofii, co dla Twardowskiego miało w tym momencie znaczenie kluczowe. Poza tym wykład Hayma był pisany na podstawie krytycznego odniesienia do Hegla, co w mniemaniu Twardowskiego upraszczało całą sprawę. Mógł w ten sposób Twardowski przez lekturę Hayma sięgać równocześnie do Resenkranza i dokonać konfrontacji ich obu. Wydaje się, że czytał też samego Hegla, a przez komentarze Rosenkranza i Hayma uzupełniał swoją wiedzę. Poza tym wykłady Hayma były zbiorem osiemnastu gotowych już wykładów, schematycznie przedstawionych i zabarwionych krytycznym nastawieniem do Hegla. Pomimo różnych opinii, wygłaszanych zarówno przez ówczesnych krytyków Hegla, jak i dzieła Hayma o Heglu, Twardowski podjął się połączenia rozważań Rosenkranza z wykładami Hayma i uzupełnieniami Fischera, licząc na możliwość uzyskania optymalnej wersji przedstawienia filozofii Hegla we własnej prezentacji. Nie oznaczało to przyjęcia zasady „,chodzenia na skróty”, lecz podjęcie rzetelnej prezentacji filozofii Hegla, wspartej na konkretnym materiale źródłowym, co oddawało i charakteryzowało $\mathrm{w}$ pełni jego podejście do rzetelnie uprawianej historii filozofii.

11 R. Haym, Hegel und seine Zeit, "Zweite Vorlesung. Hegel's Jugendbildung", s. 16-39. Wykład ten zawierał dziewięć konkretnych omówień początkowej fazy życia i zainteresowań filozoficznych Hegla. Zawierał między innymi uwagi o pierwszych latach szkolnych Hegla (,,Schulzeit und Knabenart”), stosunek Hegla do epoki Oświecenia („Humanismus und Aufklärung”), omówienie pierwszych lat studiów („Die Tübinger Universität”), stosunek Hegla do rewolucji francuskiej i Kanta („Die französische Revolution und die Kant'sche Philosophie”), a także omówienie pierwszych relacji i wpływów, przede wszystkim Hölderlina (Hölderlin und die Griechenthum").

12 Zob. ibidem.

13 Georg Ludwig Hegel pełnił funkcję Rentkammersekretär (Rentcammer-Secretarius) (zob. Briefe von und an Hegel, hrsg. von Johannes Hoffmeister, Bd. 4, Tl. 1: Dokumente und Materialien zur Biographie, hrsg. von F. Nicolin, Philosophische Bibliothek 238a Hamburg 1977, s. 9-11), czyli był urzędnikiem skarbowym księstwa wirtemberskiego (zob. Herzoglich Wirtembergisches Adreß-buch, in welchem sämtliche bey Herzogl. Hof, Canzley, löbl. Landschaft u. wie auch dem Herzogl. Militair-Etat, Hoher Karls-Schule, und auf dem Land befindliche hohe und niedere Diensterschaft bestmöglichts beschrieben auf das Jahr 1786, Stuttgart 1786, s. 26, 40). Od 1796 roku pełnił funkcję Expeditionsrat. Zmarł w 1799 roku (zob. Neues württembergisches Dienerbuch, bearb. von W. Pfeilsticker, Bd. 1: Hof, Regierung, Verwaltung, Stuttgart 1957, no. 1731).

14 Zob. Hegel's Tagebuch aus der Gymnasialzeit, s. 432-448, w: K. Rosenkranz, Georg Wilhelm Friedrich Hegel's Leben. Zob. też R. Haym, Hegel und seine Zeit, „Zweite Vorlesung. Hegel's Jugendbildung. Schulzeit und Knabenart", s. 21-24.

15 Ta część wykładu Twardowskiego łączy wykład Hayma z uwagami Rosenkranza na temat lektur Hegla w zakresie filozofii starożytnej. Zob. K. Rosenkranz, Georg Wilhelm Friedrich Hegel's Leben, "Lectüre und Methode derselben", s. 10-11. Dodajmy, że następujące tutaj u Twardowskiego omówienie młodzieńczych lektur i prób autorskich Hegla zostało dokonane szczegółowo według rozważań Rosenkranza. Zob. ibidem, s. 2-25. Są to: "Herkunft, s. 3-4; Erste Jugend, s. 4-6; Lectüre und Methode derselben, s. 6-10; Gymnasium, s. 10-15; Arbeiten aus der Gymnasialzeit, s. 15-21; Hegel's Eigenheit, s. $21-25^{\prime \prime}$. 
16 Zob. ibidem, s. 10.

17 Zob. ibidem, s. 11.

18 Ta rozprawka Hegla nosiła tytuł: Unterredung zwischen Dreien. Została napisana przez niego w okresie gimnazjalnym, a dokładnie 30 maja 1785 roku. Zamieścił ją K. Rosenkranz do swoich rozważań Georg Wilhelm Friedrich Hegel's Leben, „Urkunden. I. Arbeiten aus den Gymnasialzeit", s. 449-454. Rosenkranz omawia ją osobno w swoich rozważaniach, podobnie jak wszystkie prace Hegla z okresu młodzieńczego.

19 Druga z rozprawek Hegla z okresu gimnazjalnego nosiła tytuł Ueber die Religion der Griechen und Römer i pochodziła z 10 sierpnia 1787 roku. Zob. ibidem, s. 454458.

20 Trzecia z rozprawek Hegla nosiła tytuł: Ueber einige charakteristische Unterschiede der alten Dichter i pochodziła z 7 sierpnia 1788 roku. Zob. ibidem, s. 458-461.

21 Chodzi tu niewątpliwie o Heglowską krótką mowę komplementarną, wygłoszoną podczas nauki gimnazjalnej w listopadzie 1788 roku. Zob. ibidem, s. 19-21.

22 Zob. R. Haym, Hegel und seine Zeit, "Zweite Vorlesung. Hegel's Jugendbildung. Die französische Revolution und Kant'sche Philosophie", s. 32 i dalsze do 34.

${ }_{23}$ Zob. G. W. F. Hegel, Ueber die Religion der Griechen ud Römer, s. 458, w: K. Rosenkranz, Georg Wilhelm Friedrich Hegel's Leben.

${ }^{24}$ Dziennik Hegla z lat młodzieńczych (czerwiec 1785 - styczeń 1787) zachował się do dziś. Opublikowany (nie w całości) przez Karla Rosenkranza (zob. K. Rosenkranz, Georg Wilhelm Friedrich Hegel's Leben, s. 431-448), nie został następnie przekazany przez synów filozofa z resztą spuścizny do królewskiej biblioteki w Berlinie. Był własnością kolejnych potomków Hegla i wraz z nimi znalazł się w Stanach Zjednoczonych. W 1970 roku został wypożyczony na wystawę poświęconą Heglowi, którą zorganizowano w Stuttgarcie. Był także udostępniany w trakcie tworzenia krytycznego wydania (G. W. F. Hegel, Tagebuch 1785-1787, w: idem, Frühe Schriften I, hrsg. von F. Nicolin, G. Schüler, (G. W. F. Hegel, Gesammelte Werke, Bd. 1), Hamburg 1989, s. 1-33). W 2000 roku dziennik został zakupiony na aukcji w Londynie przez reprezentanta Staatsbibliothek i znajduje się dzisiaj w tej bibliotece $\mathrm{w}$ Berlinie pod sygnaturą Ms. germ. oct. 1376 (zob. E. Overgaauw, Der Philosoph als Gymnasialschüler. Hegels Jugendtagebuch in der Staatsbibliothek zu Berlin, „Jahrbuch Preussischer Kulturbesitz", Bd. 38 (2002), s. 407-412, zwłaszcza s. 411-412; R. Schipke, Neuerwerbungen abendländischer Handschriften für die Staatsbibliothek zu Berlin, Preußischer Kulturbesitz 1998-2007, „Mittellateinisches Jahrbuch”, 43 (2008), s. 327-346, zwłaszcza s. 337-338). Zob. też R. Haym, Hegel und seine Zeit, "Zweite Vorlesung. Hegel's Jugendbildung. Schulzeit und Knabenart", s. 21-24.

25 Zob. Hegel's Tagebuch aus der Gymnasialzeit, w: K. Rosenkranz, Georg Wilhelm Friedrich Hegel's Leben, s. 436-437.

26 Zob. ibidem, s. 437.

27 Zob. ibidem.

28 Zob. ibidem, s. 438.

29 Zob. ibidem, s. 438 i dalsze.

30 Hegel uzyskał stopień magistra na seminarium prof. Strossa, dokładnie dwa lata po immatrykulacji, broniąc tezy z sekcji 4 par. 28, wskazanej tu przez Twardowskiego rozprawy Augusta Friedricha Böka. Zob. szerzej o tym u K. Rosenkranz, Georg Wilhelm Friedrich Hegel's Leben, "Die Dissertation pro magisterio 1790”, s. 35-38. Dodajmy, że Twardowski powiela za Rosenkranzem błąd - przypisując Heglowi autorstwo pracy De limite officiorum humanorum, seposita animorum immortalitate. W rzeczywistości Hegel, by uzyskać godność magistra filozofii, przeprowadził wraz z innymi kandydatami dyskusję nad pracą swojego egzaminatora - Augusta Friedricha Böka, profesora filozofii praktycznej, wymowy i poezji z Tybingi (zob. Augusti Friderici Boekii philosophiae professoris publ. ord. in Academia Tubingensi De limite officiorum humanorum seposita animorum immortalitate commentatio prior, Tubingae 1790 (druga część ukazała się w 1792 roku)). Skorygowano ten błąd 
wkrótce po publikacji książki Rosenkranza. Sprawę na prośbę samego Rosenkranza zbadał na miejscu w Tybindze Immanuel Hermann Fichte (zob. Briefe von und an Hegel, Bd. 4, Tl. 1: Dokumente und Materialien zur Biographie, hrsg. von Friedhelm Nicolin, s. 29-30, 281-282; a także I. H. Fichte, Hegel's philosophische Magister-Dissertation und sein Verhältniß zu Schelling. Nachtrag zum Aufsatze im vorherigen Hefte: "zu Hegel's Charakteristik", "Zeitschrift für Philosophie und Spekulative Theologie”, 13 (1844) 1, s. 142-154, s. 142-143, 145-147). Błąd jednakże nadal pojawia się czasem w opracowaniach. Dla uzyskania godności magistra filozofii Hegel przedstawił także (niezachowane dziś) prace: Ueber das Urtheil des gemeinen Menschenverstands über Objectivitaet und Subjectivitaet der Vorstellungen oraz Ueber das Studium der Geschichte der Philosophie (zob. Briefe von und an Hegel, Bd. 4, Tl. 1: Dokumente und Materialien zur Biographie, s. 34, a zwłaszcza s. 286, przyp. 8).

31 Zob. K. Rosenkranz, Georg Wilhelm Friedrich Hegel's Leben, „Dissertation pro candidatura examinis consistorialis 1793", s. 38-39. Chodziło tutaj o obronę tezy 80 par. $4 \mathrm{z}$ rozprawy prof. Spittlera.

${ }_{32}$ Zob. K. Rosenkranz, Georg Wilhelm Friedrich Hegel's Leben, „Hegel, Hölderlin und Schelling", s. 40-41. Twardowski konsekwentnie podąża tutaj za wykładem Hayma i równie systematycznie uzupełnia swój wykład o uwagi Rosenkranza. Zob. też uwagi do tej kwestii R. Hayma w Hegel und seine Zeit, „Zweite Vorlesung. Hegel's Jugendbildung. Hölderlin und Griechenthum", s. 36 i dalsze do 39.

33 Mömpelgard (Monbéliard) była to wirtemberska enklawa na terenie Francji (w Alzacji). Wśród towarzyszy Hegla w tybińskim Stifcie byli też studenci pochodzący z tego obszaru (będąc poddanymi księcia, mieli prawo tam się uczyć) (zob. T. Pinkard, Hegel. A Biography, Cambridge 2000, s. 23-24). Wydaje się, że Twardowski nie do końca rozczytał w tym miejscu fragment $\mathrm{z}$ tekstu Rosenkranza (zob. K. Rosenkranz, Georg Wilhelm Friedrich Hegel's Leben, s. 30-31). Dokładna lektura tego passusu jasno wskazuje, że Hegel nawiązywał z tymi studentami bardzo dobre stosunki. Ponadto Kuno Fischer (zob. K. Fischer, Geschichte der neuern Philosophie, Bd. 8: Hegels Leben, Werke und Lehre, Tl. 1, Heidelberg 1901, „Erstes Buch: Hegels Leben und Werke, Erstes Capitel: Herkunft und Lehrjahre, II: Die akademischen Lehrjahre in Tübingen, 1. Studiengang. Magisterium und Candidatur", s. 12-13) zauważa, że to właśnie ci studenci przynieśli do Stiftu rewolucyjny powiew (szerzej zob. J. Schweigard, Studentische Netzwerke im Zeichen der Französischen Revolution. Politische Gruppenbildungen, Meinungstransfers und Symbole an süddeutschen Hochschulen (1791-1794), „Auklärung”, 24 (2012), s. 317-344, zwłaszcza s. 327-331). Zob. też uwagi R. Hayma w Hegel und seine Zeit, "Zweite Vorlesung. Hegel's Jugendbildung. Die französische revolution und Kant'sche Philosophie", s. 32 i dalsze do 34.

34 Hegel w 1791 roku zakochał się bez wzajemności w Auguste Hegelmaier (Augustine), córce zmarłego tybińskiego profesora teologii Tobiasa Gottfrieda Hegelmaiera. W Sztambuchu Hegla znajdują się wpisy jego przyjaciół dotyczące tej szesnastoletniej dziewczyny. Hegel również zamieścił dotyczącą niej notkę w albumie J. C. F. Finka. Augusta podawała wino w jednym z lokali, w którym Hegel i jego przyjaciele spędzali wolny czas. Ostatecznie w 1798 roku wyszła za mąż za Eberharda Ludwiga Augusta Krippendorfa, także absolwenta tybińskiego Stiftu, w późniejszym czasie pełniącego wysokie funkcje $\mathrm{w}$ wielkoksiążęcym badeńskim wymiarze sprawiedliwości (zob. Briefe von und an Hegel, Bd. 4, Tl. 1: Dokumente und Materialien zur Biographie, 3., völlig neubearb. Aufl., (Philosophische Bibliothek 238a), s. 135, 150, 154, 165, a także adnotacje K. Rosenkranza w Briefe 1827 bis 1850, hrsg. von J. Butzlaff, (Quellen und Studien zur Philosophie 37) Berlin - New York 1994, s. 249, przyp. 1 oraz Hegel in Berichten seiner Zeitgenossen, hrsg. von Günther Nicolin, (Philosophische Bibliothek 245) Hamburg 1970, s. 17-18). W literaturze naukowej nadal podaje się błędnie 10 października 1840 roku jako datę śmierci Augusty Krippendorff (zob. T. Pinkard, Hegel. A Biography, s. 671, przyp. 15). W rzeczywistości wówczas zmarł jej mąż (zob. Grossherzoglich Badisches Staats-und Regierungs-Blatt nr 39 z 12 grudnia 1840 r., s. 318, a także Handbuch für Baden und seine Diener oder Ve- 
rzeichniß aller badischen Diener vom Jahr 1790 bis 1840, nebst Nachtrag bis 1845, Heidelberg 1846, s. 116).

${ }_{35}$ Zob. R. Haym, Hegel und seine Zeit, „Dritte Vorlesung. Das theologische System", s. 40-61. Twardowski, podążając za trzecim z kolei wykładem Hayma, stara się wiernie oddać czas pobytu Hegla w Szwajcarii, a głównie na posadzie nauczyciela prywatnego w Bernie. Dominujące wydaje się tutaj oddziaływanie filozofii Kanta („Kant'scher Ausgagangspunkt für dieselben”), zainteresowania teologiczne, związane z powstawaniem pierwszych w pełni samodzielnych prac Hegla („Theologische Arbeiten daselbst"), a także zależności między filozofią grecką a chrystianizmem („Verhältniß zwischen dem Classischen und Christlichen nach der Seite und Uebereinstimmung und des Unterschieds"). W dalszym ciągu następują też odwołania i nawiązania do Rosenkranza, a także do pracy Fischera o Heglu.

36 Zob. K. Rosenkranz, Georg Wilhelm Friedrich Hegel's Leben, „Hegel als Hauslehrer in der Schweiz. Herbst 1793 bis Herbst 1996", s. 41-45, a także „Theologische und historische Studien der Schweizer Periode", s. 45-62.

${ }_{37}$ Zob. R. Haym, Hegel und seine Zeit, „Dritte Vorlesung. Das theologische System. Theologische Arbeiten in der Schweiz", s. 40-43.

38 Zob. ibidem, „Kant'scher Ausgangspunkt für dieselben. Briefwechsel mit Schelling", s. 44-45. Te rozważania Hayma Twardowski uzupełnia o lekturę Rosenkranza. Czyta też listy Hegla z Berna do Schellinga, które są zamieszczone przez Rosenkranza w Georg Wilhelm Friedrich Hegel's Leben, „Briefwechsel Hegel's mit Schelling", s. 62-75. Zob. też list Schellinga do Hegla z 4 lutego 1795 roku, s. 20-23, a także list Hegla do Schellinga z 16 kwietnia 1795 roku, w: Briefe von und an Hegel, hrsg. von J. Hoffmeister, Bd. 1: 1785-1812 (G. W. F. Hegel, Sämtliche Werke 27; Philosophische Bibliothek 235), Hamburg 1952, s. 23-26. Twardowski odnajduje w tych listach przede wszystkim uwagi w sprawie filozofii Kanta, zwłaszcza jej strony praktycznej. Sięga też i rozważa wpływ Fichtego na Schellinga, czytając jednocześnie prace Schellinga i interesującą go korespondencję Hegla z Schellingiem.

39 Zob. List Hegla do Schellinga z Berna z 30 sierpnia 1795 roku, w: Briefe von und an Hegel, hrsg. von J. Hoffmeister, Bd. 1: 1785-1812 (G. W. F. Hegel, Sämtliche Werke 27; Philosophische Bibliothek 235), Hamburg 1952, s. 29. Zob. też K. Rosenkranz, Georg Wilhelm Friedrich Hegel's Leben, „Briefwechsel Hegel's mit Schelling”, s. 74

${ }_{40}$ Zob. K. Fischer, Geschichte der neuern Philosophie, Bd. 8: Hegels Leben, Werke und Lehre, Tl. 1, Heidelberg 1901, „Erstes Buch: Hegels Leben und Werke, Drittes Capitel: Fortsetzung. Hegels Studien in der Schweiz, I: Die einflußreichen Zeitbegebenheiten. 1. Philosophie. Fichte und Schelling", s. 25-26.

${ }_{41}$ Wnikliwej analizie poddaje też Twardowski listy Hegla z Hölderlinem, które czyta w oryginale i także znajduje u Rosenkranza. Zob. zwłaszcza List Hegla do Hölderlina z sierpnia 1796 roku, list Hölderlina do Hegla z 24 października 1796 roku, list Hegla do Hölderlina z listopada 1796 roku oraz list Hölderlina do Hegla z 20 listopada 1796 roku w: Briefe von und an Hegel, hrsg. von J. Hoffmeister, Bd. 1: 1785-1812, (G. W. F. Hegel, Sämtliche Werke 27; Philosophische Bibliothek 235) Hamburg 1952, s. 38-49. Zob. też uwagi K. Rosenkranza w Georg Wilhelm Friedrich Hegel's Leben, „Briefwechsel Hegel's mit Hölderlin”, s. 76-80 .

42 Zob. K. Rosenkranz, Georg Wilhelm Friedrich Hegel's Leben, „Theologische und historische Studien der Schweizer Periode", s. 54-55. Należy podkreślić, że Twardowski podaje za Rosenkranzem całą grupę tekstów, które Rosenkranz wydzielił ze spuścizny Hegla. Ponowne opracowanie manuskryptów Hegla przez ucznia Diltheya - Hermana Nohla - doprowadziło do zupełnie innego podziału tej części spuścizny. Nohl uznał postulowane przez Rosenkranza Die Geschichte der Juden, Das Schicksal und seine Versöhnung, Der Gottes-und Menschensohn, Das Abendmahl i Die Taufe za fragmenty szerszej pracy Der Geist des Christentums und sein Schicksal (tytuł pochodzi od Nohla). Niektóre części wydzielonych uprzednio przez Rosenkranza prac przyporządkował w inny sposób. Część Die Geschichte der Juden uznał 
za fragment trzeci z Entwürfe zum Geist des Judentums. Fragment Das Schicksal und seine Versöhnung przyporządkował do szkicu Das Grundkonzept zum Geist des Christentums. Utwór Die Liebe und die Scham odnalazł w nieco szerszej wersji i opublikował jako fragment „welchem Zwecke denn alles Übrige dient...". Prócz tego, według Nohla, manuskrypt tekstu, który Rosenkranz określił jako Das Wunder nie zachował się Nohl podał go za Rosenkranzem. Nohl zdecydował się przyporządkować go jako (niezachowaną) część wspomnianego już wyżej tekstu „Die Positivität der christlichen Religion" (zob. Hegels theologische Jugendschriften nach den Handschriften der Kgl. Bibliothek in Berlin, hrsg. von Herman Nohl, Tübingen 1907, s. 231-232, 243, przyp. 1, 258-260, 280-287, 297-301, 306-311, 319, 323-324, 342, 370, 378-380, 393). I tak chociażby poszczególne partie tekstu nazwanego przez Nohla Der Geist des Christentums und sein Schicksal (zob. ibidem, s. 243, przyp. 1) Hegel pisał w Bernie i Frankfurcie, rozpoczynając prace przed początkiem 1797 roku, ale przeróbek dokonywał prawdopodobnie jeszcze w 1800 roku (zob. E. Ziesche, Der handschriftliche Nachlaß Georg Wilhelm Friedrich Hegels und die Hegel-Bestände der Staatsbibliothek zu Berlin Preussischer Kulturbesitz, Tl. 1: Katalog, (Kataloge der Handschriftenabteilung. Staatsbibliothek zu Berlin - Preußischer Kulturbesitz 4) Wiesbaden 1995, s. 95-109). Do jednej z wczesnych wersji tego utworu należy szkic Das Grundkonzept zum Geist des Christentums, wraz z fragmentem "welchem Zwecke denn alles Übrige dient...", datowanym na około listopada 1797 roku z modyfikacją dokonaną jesienią 1798 roku lub zimą 1798/1799 (zob. G. Schüler, Zur Chronologie von Hegels Jugendschriften, „Hegel-Studien", Nr. 2, 1963, s. 131-132, 147). Natomiast trzeci, najwcześniejszy z Entwürfe zum Geist des Judentums powstał jesienią 1796 lub na początku 1797 (zob. ibidem, s. 131, 146). Z kolei Życie Jezusa (Das Leben Jesu) powstało między 9 maja a 24 lipca 1795 roku (zob. Hegels theologische Jugendschriften nach den Handschriften der Kgl. Bibliothek in Berlin, s. 75, przyp. 1). Dzieło zostało więc napisane w okresie berneńskim, najprawdopodobniej w posiadłości pracodawcy Hegla w Tschugg. W owym okresie filozof z pewnością tam przebywał (stamtąd pisał wówczas listy), podejmując jedynie pod koniec maja 1795 roku wycieczkę do Genewy, o czym świadczą zachowane dokumenty. Tytuł nie pochodzi od autora, lecz został przyjęty za Rosenkranzem (zob. G. Schüler, Zur Chronologie von Hegels Jugendschriften, "Hegel-Studien”, Nr. 2, 1963, s. 142, przyp. 71). Dzieło nie zostało opublikowane za życia Hegla, nie zabiegał on o jego wydanie, gdyż był niezadowolony z tekstu. Uwaga ta zresztą dotyczy wszystkich jego prac z okresu berneńskiego. Wyjątek stanowi dokonane przez niego tłumaczenie na język niemiecki pracy Jeana-Jacquesa Carta dotyczącej wpływów politycznych berneńskiej oligarchii na kanton Vaud, który to tekst Hegel opatrzył także wstępem i wieloma uwagami, a następnie anonimowo opublikował (zob. Vertrauliche über das vormalige statsrechtliche Verhältniß des Waadtlandes (Pays de Vaud) zur Stadt Bern. Eine völlige Aufdeckung der ehemaligen Oligarchie des Standes Bern. Aus dem Französischen eines verstorbenen Schweizers übersetzt und mit Anmerkungen versehen, Frankfurt am Main 1798, a także H. Falkenheim, Eine unbekannte politische Druckschrift Hegels, „Preußische Jahrbücher”, Nr. 138, 1909, H. 2, s. 193-220). Jeszcze inna rozprawa, przypominająca pracę Fichtego, a mianowicie Kritik des Begriffs der positiven Religion (1796) powstała w okresie berneńskim, była różnie nazywana przez poszczególnych badaczy. Twardowski podaje tytuł Rosenkranza, według Thomsena jest to Kritik des Christentums als positiver Religion, Dilthey nazwał ją Über das Verhältnis der Vernunftreligion zur positiven Religion, wreszcie Nohl - Die Positivität der christlichen Religion (ten tytuł przyjmuje się obecnie powszechnie) (zob. A. Thomsen, Aus Hegels Frühzeit, „Kantstudien”, Nr. 12, 1907, s. 407-416, zwłaszcza s. 412). Utwór jest niekompletny, gdyż brakuje początku (nie zachował się). Duża część tekstu została napisana przed 2 listopada 1795 roku, a zakończenie dołączone 29 kwietnia 1796 roku. Początek tekstu Hegel znacznie rozszerzył w październiku 1800 roku (zob. Hegels theologische Jugendschriften nach den Handschriften der Kgl. Bibliothek in Berlin, s. 140, przyp. 1). 
43 Zob. G. W. F. Hegel, Eleusis. An Hölderlin (1796), w: idem, Werke in zwanzig Bänden, Bd. 1, „Frühe Schriften”, s. 230-234, zwłaszcza s. 230.

44 Zob. List Schellinga do Hegla z 6 stycznia 1795 roku w: Briefe von und an Hegel, hrsg. von J. Hoffmeister, Bd. 1: 1785-1812 (G. W. F. Hegel, Sämtliche Werke 27; Philosophische Bibliothek 235), Hamburg 1952, s. 13. Zob. też R. Haym, Hegel und seine Zeit, „Dritte Vorlesung. Das theologische System”, s. 44. Twardowski powraca w tym momencie do wykładu Hayma. Ta charakterystyka relacji Schelling-Hegel przebiega zdecydowanie za uwagami i refleksjami Hayma.

${ }_{45}$ Zob. List Schellinga do Hegla z 4 lutego 1795 roku, będący odpowiedzią na wcześniejszy list Hegla do Schellinga z Berna, list bez daty z 1795 roku, w: Briefe von und an Hegel, hrsg. von J. Hoffmeister, Bd. 1: 1785-1812 (G. W. F. Hegel, Sämtliche Werke 27; Philosophische Bibliothek 235), Hamburg 1952, s. 20-23. List ten zawarty jest także w K. Rosenkranza Georg Wilhelm Friedrich Hegel's Leben, „Briefwechsel Hegel's mit Schelling", s. 66-69.

${ }_{46}$ Następujący tutaj fragment rozważań Twardowskiego jest relacją z części wykładu Hayma Hegel und seine Zeit, „Dritte Vorlesung. Das theologische System”, s. $44-49$.

47 Zob. ibidem, s. 44-45 i dalsze. Twardowski odwołuje się oczywiście w tym momencie przede wszystkim do dzieła Hegla (Das Leben Jesu), a dopiero później korzysta z komentarzy Hayma i Rosenkranza.

48 Zob. ibidem, s. 46 i dalsze.

49 Zob. ibidem, s. 50-51. Por. rozważania Hayma z uwagami Rosenkranza w Georg Wilhelm Friedrich Hegel's Leben, "Theologische und historische Studien der Schweizer Periode", s. 57-58.

50 Zob. R. Haym, Hegel und seine Zeit, „Dritte Vorlesung. Das theologische System", s. 52.

51 Por. ibidem, s. 50-53 i dalsze.

52 Zob. ibidem, „Hinzutreten des ästhetisch-humanistischen Moments”, s. 52$-53$.

53 Zob. ibidem. Por. uwagi Hayma z rozważaniami Rosenkranza w Georg Wilhelm Friedrich Hegel's Leben, „Theologische und historische Studien der Schweizer Periode", s. 59-61.

${ }_{54}$ Zob. R. Haym, Hegel und seine Zeit, „Dritte Vorlesung. Das theologische System", s. 54-61.

${ }_{55}$ Zob. R. Haym, Hegel und seine Zeit, „Vierte Vorlesung. Der Uebergang zum philosophischen System", s. 62-92. Twardowski podąża w dalszym ciągu za wykładem Hayma i ukazuje na jego podstawie drogę Hegla do systemu. Przedziera się przez okres przejściowy od Berna do Frankfurtu nad Menem („,Von Bern nach Frankfurt am Main”). Opisuje studia polityczne Hegla („Politische Studien”, „,Kritik der Wirtembergischen Zustände”, „Der allgemeine Zustand Deutschlands”, „Studien über die deutsche Reichsverfassung"). Wskazuje także za Haymem powoływane do życia podstawy systemu filozoficznego Hegla (,Die Metaphysik als Vermittlerin zwischen Ideal und Wirklichkeit”, "Gleichzeitige neue Vertiefung in das Wesen der Religion”, „Der letzte Schritt zum System”, „Eigenthümlicher Ursprung der Hegel'schen Philosophie"). Wykład Hayma wspiera dodatkowo Twardowski odwołaniami do prac Hegla z tego okresu, a także powołuje się na rozważania Rosenkranza i Fischera.

56 Zob. R. Haym, Hegel und seine Zeit, „Vierte Vorlesung. Der Uebergang zum philosophischen System. Politische Studien”, s. 64-66. Zob. też K. Rosenkranz, Georg Wilhelm Friedrich Hegel's Leben, „Theologische und historische Studien der Schweizer Periode. Politische Studien", s. 85-94. Z obu wykładów Twardowski wywnioskował, że w czasie przełomu berneńsko-frankfurckiego wzrosło u Hegla zainteresowanie filozofią polityczną, a zwłaszcza reformą państwa. Wyrazem tego miała być krótka rozprawka o wojsku i zmianach ustrojowych, a także analiza systemu zarządzania kantonem brenejskim, co w niedługiej przyszłości miało u Hegla zaowocować pow- 
staniem większej rozprawy na ten temat. Z tego okresu pochodzą Heglowskie Fragmente historischer und politischer Studien aus der Berner und Frankfurter Zeit (frag. 17951798).

7 Zob. List Hölderlina do Hegla z 20 października 1796 roku, w: Briefe von und an Hegel, hrsg. von J. Hoffmeister, Bd. 1: 1785-1812 (G. W. F. Hegel, Sämtliche Werke 27; Philosophische Bibliothek 235), Hamburg 1952, s. 40-42. Dodajmy, że jako pierwszy swój list napisał Hegel. Pochodził on z sierpnia 1796 roku (ibidem, s. 38-40). List Hölderlina był odpowiedzią na ten list. W 1796 roku obaj napisali do siebie jeszcze po jednym liście. Zob. List Hegla do Hölderlina z listopada 1796 roku (ibidem, s. 42-44) i List Hölderlina do Hegla z 20 listopada 1796 roku (ibidem, s. 44-49). W listach tych doszło do wymiany poglądów oraz porozumienia co do objęcia przez Hegla posady we Frankfurcie nad Menem.

58 Zob. K. Fischer, Geschichte der neuern Philosophie, Bd. 8: Hegels Leben, Werke und Lehre, Tl. 1, Heidelberg 1901, „Erstes Buch: Hegels Leben und Werke, Viertes Capitel: Das Ende des Aufenthaltes in der Schweiz. Hegel und Hölderlin. Uebersiedlung nach Frankfurt, III: Hegel im Hause Gogel, 1: Stellung"', s. 41.

${ }_{59}$ Zob. R. Haym, Hegel und seine Zeit, „Vierte Vorlesung. Der Uebergang zum philosophischen System. Von Bern nach Frankfurt am Main", s. 62-64.

60 Twardowski odwołuje się tutaj do pisanych przez Hegla w latach 1796-1797 Das älteste Systemprogramm des deutschen Idealismus, s. 234-239, w: idem, Werke in zwanzig Bänden, „I. Frühe Schriften”.

${ }_{61}$ Zob. G. W. F. Hegel, Daß die Magistrate von den Bürgern gewählt werden müssen (Über die neusten inneren Verhältnisse Württembergs, besonders über die Gebrechen der Magistratsverfassung), s. 268-274, w: idem, Werke in zwanzig Bänden, „I. Frühe Schriften”. Zob. też rozważania na ten ten temat R. Haym, Hegel und seine Zeit, „Vierte Vorlesung. Der Uebergang zum philosophischen System. Kritik der Wirtembergischen Zustände", s. 66-68. Por. też K. Rosenkranz, Georg Wilhelm Friedrich Hegel's Leben, "Theologische und historische Studien der Schweizer Periode. Politische Studien", s. 91-94. Hegel zanim osiadł we Frankfurcie spędził krótki czas w swoim rodzinnym mieście - Stuttgarcie w Wirtembergii, gdzie wśród interwencji wojsk francuskich i austriackich toczyła się polityczna walka o przyszły ustrój tego kraju (zakończona ostatecznie utwierdzeniem monarchii przy poparciu francuskim). Spory publicystyczne, które wówczas trwały, skłoniły Hegla do napisania (już po przybyciu do Frankfurtu) tekstu wspierającego przemiany demokratyczne. Praca ta powstała latem 1798 roku (przed 7 sierpnia). Znana jest pod tytułem Über die neusten inneren Verhältnisse Württembergs, besonders über die Gebrechen der Magistratsverfassung. Nie jest to jednak nazwa nadana przez autora. Hegel zatytułował ją Daß die Magistrate von den Bürgern gewählt werden müssen. Lektura tekstu została dokonana przez trzech stuttgardzkich znajomych przyszłego filozofa. Skłonili go do pozostawienia pracy jedynie $w$ rękopisie. Hegel postąpił zgodnie $z$ radami, zamiast tego opublikował anonimowo tłumaczenie pracy Carta o regionie (późniejszym kantonie) Vaud (zob. T. Pinkard, Hegel. A Biography, s. 73-76; G. Schüler, Zur Chronologie von Hegels Jugendschriften, w: „Hegel-Studien”, Bd. 2, 1963, s. 111-159, zwłaszcza s. 132, 148; E. Ziesche, Der handschriftliche Nachlaß, Tl. 1, s. 141).

62 Twardowski odwołuje się tutaj do tekstu Hegla Die Verfassung Deutschlands, który został spisany i usystematyzowany w całość przez Hegla po opuszczeniu Frankfurtu nad Menem. We Frankfurcie nad Menem powstały „Erste Entwürfe einer Einleitung zur Verfassungsschrift”, a zwłaszcza „Vorrede” (1799/1801), w której już na samym początku pada przytoczona przez Twardowskiego teza, że „Niemcy nie są państwem” (s. 452, "Deutschland kein Staat mehr"). Zob. G. W. F. Hegel, Die Verfassung Deutschlands, "Erste Entwürfe einer Einleitung zur Verfassungsschrift”, s. 451-461, w: ibidem, Werke in zwanzig Bänden, „I. Frühe Schriften”.

63 Hegel tezę: "Deutschland ist kein Staat mehr" powtarza już w pierwszym zdaniu rozważań głównych. Zob. G. W. F. Hegel, Die Verfassung Deutschlands, 
„B.Die Verfassung Deutschlands. Einleitung”, s. 461, w: idem, Werke in zwanzig Bänden, „I. Frühe Schriften”.

64 Zob. ibidem.

65 Zob. G. W. F. Hegel, Die Verfassung Deutschlands, „Einleitung (1799/1800)”, s. 458, w: idem, Werke in zwanzig Bänden, „I. Frühe Schriften”.

${ }_{66}$ Zob. ibidem. Ten cały fragment jest doskonałym streszczeniem tekstu Hegla, dokonanym przez Twardowskiego. Widać tutaj, że czytał nie tylko doskonałe komentarze Hayma czy też Rosenkranza, lecz sięgał bezpośrednio po oryginały prac Hegla.

${ }_{67}$ Zob. G. W. F. Hegel, Die Verfassung Deutschlands, „B. Die Verfassung Deutschlands. Einleitung", s. 458 i dalsze.

68 Twardowski odwołuje się tutaj do tekstu Hegla, który został przez niego napisany w Bernie w latach 1795/1796 Die Positivität der christlichen Religion, s. 104190, w: idem, Werke in zwanzig Bänden, „I. Frühe Schriften”. Ten tekst, jak dalej podkreśla, we Frankfurcie został przeredagowany i uzupełniony przez Hegla. Powstał wówczas w latach 1798-1800 Der Geist des Christentums und sein Schicksal wraz z uzupełnieniami: zmieniony wstęp, tj. „Der Geist des Judentums”, s. 274297, "Grundkonzept zum Geist des Christentums”, s. 297-317, oraz „Der Geist des Christentums”, s. 317-419, w: idem, Werke in zwanzig Bänden, „I. Frühe Schriften”. Twardowski przeanalizował te dwa teksty, zarówno berneński, jak i frankfurcki. Czytał również berneńskie Fragmente über Volksreligion und Christentum, s. 9-104, w: idem, Werke in zwanzig Bänden, "I. Frühe Schriften”, pisane przez Hegla w latach 1793-1794. W swoim wykładzie korzystał też z uwag R. Haym, Hegel und seine Zeit, „Vierte Vorlesung. Der Uebergang zum philosophischen System”, s. 82-86. Por. też K. Rosenkranz, Georg Wilhelm Friedrich Hegel's Leben, "Theologische und historische Studien der Schweizer Periode. Wideraufnahme der Kritik der positiven Religion", s. 94-99.

${ }^{69}$ Zob. G. W. F. Hegel, Der Geist des Christentums und sein Schicksal wraz z uzupełnieniami: zmieniony wstęp, tj. „Der Geist des Judentums”, s. 274-297 w: idem, Werke in zwanzig Bänden, "I. Frühe Schriften”. Zob. też R. Haym, Hegel und seine Zeit, „Vierte Vorlesung. Der Uebergang zum philosophischen System”, s. 82-86.

70 Zob. G. W. F. Hegel, Der Geist des Christentums und sein Schicksal, "Grundkonzept zum Geist des Christentums", s. 297-317, w: idem, Werke in zwanzig Bänden, „I. Frühe Schriften”. Por. też K. Rosenkranz, Georg Wilhelm Friedrich Hegel's Leben, "Theologische und historische Studien der Schweizer Periode. Wideraufnahme der Kritik der positiven Religion", s. 94-99.

${ }^{71}$ Zob. ibidem. Zob. też R. Haym, Hegel und seine Zeit, „Vierte Vorlesung. Der Uebergang zum philosophischen System", s. 82-86. Dodajmy, że koncepcja Hegla (pojęcie „,życia”) w późniejszym okresie zostało zastąpione pojęciem „ducha”. Miało to również oddziaływanie na koncepcję Wilhelma Diltheya, a w czasach nam bliższych kluczową rolę odegrało u Ortegi y Gasseta.

72 Zob. G. W. F. Hegel, Der Geist des Christentums und sein Schicksal, „Grundkonzept zum Geist des Christentums", s. 297-317, w: idem, Werke in zwanzig Bänden, „I. Frühe Schriften”. Por. też K. Rosenkranz, Georg Wilhelm Friedrich Hegel's Leben, „Theologische und historische Studien der Schweizer Periode. Wideraufnahme der Kritik der positiven Religion", s. 94-99.

73 Zob. bezpośrednie odwołanie Twardowskiego do tekstu Rosenkranza (podana tam data ukończenia tekstu Hegla). Zob. K. Rosenkranz, Georg Wilhelm Friedrich Hegel's Leben, "Theologische und historische Studien der Schweizer Periode. Wideraufnahme der Kritik der positiven Religion", s. 99.

${ }_{74}$ Twardowski słusznie zauważa, że „w ten sposób powstaje pierwszy zarys systemu Hegla". Chodzi oczywiście o Heglowski Systemfragment von 1800, s. 419-428, w: idem, Werke in zwanzig Bänden, „I. Frühe Schriften”. Myśli też, o czym wspomina nieco dalej, o 132 stronicowym, frankfurckim zarysie systemu Hegla bądź też, jak wspomina o tym za Haymem, o "pierwszym wprowadzeniu do sytemu Hegla”. 
75 Zob. List Hegla do Schellinga z 2 listopada 1800 roku, w: Briefe von und an Hegel, hrsg. von J. Hoffmeister, Bd. 1: 1785-1812 (G. W. F. Hegel, Sämtliche Werke 27; Philosophische Bibliothek 235), Hamburg 1952, s. 58-63. Dodajmy, że był to pierwszy list Hegla do Schellinga po pięcioletniej przerwie.

76 Zob. R. Haym, Hegel und seine Zeit, „Vierte Vorlesung. Der Uebergang zum philosophischen System. Die Metaphysik als Vertiesung in das Wesen der Religion", s. 82. Twardowski odwołuje się tutaj wprost do tekstu Hayma.

${ }_{77}$ Hölderlin w styczniu 1796 roku rozpoczął pracę jako nauczyciel dzieci frankfurckiego bankiera Jakoba Friedricha Gontarda. Wkrótce zakochał się w żonie swojego pracodawcy - Susette. Na tym tle doszło we wrześniu 1798 roku do konfliktu męża z Hölderlinem, ten drugi został zmuszony do szukania innego pracodawcy. Kontakty Hölderlina z Susette Gontard utrzymywały się jeszcze przez pewien czas, aż do wyjazdu poety z Frankfurtu. Zob. T. Pinkard, Hegel. A Biography, s. 78. Szerzej o tym traktuje też K. Fischer, Geschichte der neuern Philosophie, Bd. 8: Hegels Leben, Werke und Lehre, Tl. 1, Heidelberg 1901, „Erstes Buch: Hegels Leben und Werke, Viertes Capitel: Das Ende des Aufenthaltes in der Schweiz. Hegel und Hölderlin. Uebersiedlung nach Frankfurt, II: Hölderlin im Hause Gontard, 1: Die Katastrophe", s. 39-40.

${ }_{78}$ Zob. ibidem, „Viertes Capitel: Das Ende des Aufenthaltes in der Schweiz. Hegel und Hölderlin. Uebersiedlung nach Frankfurt, III: Hegel im Hause Gogel, 3: Tod des Vaters. Oekonomische Lage", s. 42.

79 Zob. List Hegla do Schellinga z 2 listopada 1800 roku, w: Briefe von und an Hegel, hrsg. von J. Hoffmeister, Bd. 1: 1785-1812 (G. W. F. Hegel, Sämtliche Werke 27; Philosophische Bibliothek 235), Hamburg 1952, s. 58-63.

80 Zob. R. Haym, Hegel und seine Zeit, „Fünfte Vorlessung”, s. 93-123. Dodajmy, że Twardowski oparł swoje rozważania o pierwszym zarysie systemu Hegla na tych uwagach Hayma. Odwoływał się również ponownie do Rosenkranza i sięgał też do Fischera. Zachował zatem systematycznie powtarzaną przez siebie dotąd kolejność. Streszczenie Heglowskiego zarysu systemu, którego tu dokonał na podstawie wskazanych komentarzy, jest też jedynym takim w naszej literaturze filozoficznej. Nie znamy innej pracy, która by przedstawiała 132-stronicowy zarys systemu Hegla $\mathrm{z}$ okresu frankfurckiego, tuż przed przenosinami do Jeny.

81 Zob. List Hegla do Schellinga z 2 listopada 1800 roku, w: Briefe von und an Hegel, hrsg. von J. Hoffmeister, Bd. 1: 1785-1812 (G. W. F. Hegel, Sämtliche Werke 27; Philosophische Bibliothek 235), Hamburg 1952, s. 58-63, a zwłaszcza 60-63.

82 Zob. K. Rosenkranz, Georg Wilhelm Friedrich Hegel's Leben, „Erstes Buch. Das System”, s. 99-103, „Das System. I. Die logische Idee”, s. 104-111, „Das System. II. Die Natur”, s. 112-123, "Das System. III. Der Geist”, s. 124-141.

83 Jak już wskazaliśmy, Twardowski oparł swój wykład na temat „Wprowadzenia do Heglowskiego systemu" z 1800 roku, tuż przed przenosinami do Jeny, na podstawie 132-stronicowego rękopiśmienniczego tekstu Hegla, omawianego w wykładzie Hayma. Jest to „Fünftes Vorlesung. Der erste Entwurf des philosophischen System" i zawierał 13 rozbudowanych formuł opisowych, w których Haym starał się wiernie odtworzyć treść 132-stronicowego zarysu systemu Hegla. Jego uwagi różnią się od rozważań Rosenkranza. Nie odbiegają jednak aż tak daleko od nich. Haym, jak zauważa Twardowski, dysponował oryginałem Heglowskiego tekstu. Dało mu to możliwość dokonania dokładnego streszczenia. Sam Twardowski starał się wiernie podążać za Haymem, co nie oznacza, że rezygnował w tym momencie z Rosenkranza. Trzeba też zauważyć, że u Twardowskiego mogła wystąpić istotna pomyłka: podaje on "132 arkusze”. U Rosenkranza (zob. K. Rosenkranz, Georg Wilhelm Friedrich Hegel's Leben, s. 102) i u Hayma (R. Haym, Hegel und seine Zeit. Vorlesungen über Entstehung und Entwicklung, Wesen und Werth der Hegel'schen Philosophie, Berlin 1857, s. 493, przyp. 1) podana jest liczba: 102 arkuszy. Wydaje się, że nie możemy dotrzeć bezpośrednio do tej wersji „manuskryptu” w formie widzianej przez Rosenkranza i Hayma. Wynika to z faktu, że Rosenkranz i Haym mieli dostęp do spuścizny Hegla w momencie, gdy w większości jeszcze 
znajdowała się ona u rodziny (żony, potem synów). Jak wynika z badań (zob. E. Ziesche, Der handschriftliche Nachlaß, Tl. 1, s. 57-58, 94, 109), w 1889 roku papiery Hegla (nie wszystkie) zostały przekazane do Biblioteki Królewskiej w Berlinie i tam były trzymane bez oprawy w 4 „Kapseln” (pojemnikach). W 1904 roku zbiory te oprawiono w 14 tomów, a dla każdego z nich została ustalona paginacja. Jeśli chodzi o części Jugendschriften (Theologische Jugendschriften), w tym teologicznych pism z Frankfurtu, sprawa jest jeszcze bardziej skomplikowana, bo w 1906 roku, gdy Herman Nohl opracowywał edycję tych manuskryptów, te akurat tomy rozbindowano. Nohl na podstawie swoich badań ustalił ich nowy porządek. Opierając się w dużej mierze na ustaleniach Nohla, karty z tomów 7, 8 i 11 ustawiono według nowej, zupełnie innej kolejności i oprawiono w nowe tomy 7, 8, 11, a część dodano do tomu 12. Ustalono dla tych tomów także nową paginację. W tym tomie "Nachlass Hegel 11”, obejmującym obecnie 168 luźnych kart („Manuskripte wurden 1958 wieder aus dem Einband gelöst"), na kartach 162-169 (z kartą tytułową 161a) znajdują się dwa fragmenty tekstu ukończonego 14 września 1800 we Frankfurcie, które są nazywane zbiorczo w katalogu jako „Über den Begriff der Religion”. Od czasu edycji Nohla (Hegels theologische Jugendschriften nach den Handschriften der Kgl. Bibliothek in Berlin, hrsg. von Herman Nohl, Tübingen 1907, s. 343-351) tekst ten funkcjonował jednak zwykle jako "Systemfragment von 1800" (cytowany też - od słów go rozpocznynających - jako fragment „(...) absolute Entgegensetzung gilt.”). Podobnie w tłumaczeniu angielskim: G. W. F. Hegel, Fragment of a System, transl. by Richard Kroner, w: idem, Early theological writings, transl. by T. M. Knox, with an introduction, and fragments translated by Richard Kroner, (Works in Continental Philosophy) Philadelphia 1971, s. 309-319 [oryg. publ. 1948]. Tekst ten, jak się przypuszcza, w pełnej (do dziś nie zachowanej) wersji miał około 50 arkuszy, najprawdopodobniej 47. Nie wiemy więc, w jakim związku pozostaje to do wspomnianego przez Twardowskiego rękopisu. By sprawę jeszcze zagmatwać, Dilthey (zob. W. Dilthey, Die Jugendgeschichte Hegels, (Abhandlungen der Königlich Preussischen Akademie der Wissenschaften. Philosophisch-historische Klasse 1905, 4), Berlin 1905, s. 207) zwrócił uwagę, że Rosenkranz i Haym mieli do dyspozycji prace Hegla, które „już nie są zachowane w spuściźnie, którą dzisiaj mamy w Bibliotece Królewskiej". Z kolei Herman Nohl, wydając później ponownie pracę Diltheya (zob. W. Dilthey, Die Jugendgeschichte Hegels und andere Abhandlungen zur Geschichte des Deutschen Idealismus, (Wilhelm Diltheys Gesammelte Schriften 4) Leipzig-Berlin 1921, s. 576), podaje, że to właśnie na jego wniosek dokonano nowego podziału tomów "theologische Jugendschriften” Hegla w Bibliotece Królewskiej (o czym pisalismy wyżej). (E. Ziesche, Der handschriftliche Nachlaß, Tl. 1, s. 79). Trochę podobny układ do wspomnianego przez Twardowskiego, a opisanego przez Rosenkranza rękopisu (s. 102-103: „Es beginnt mit dem Begriff des abstracten Seins, enthält die ganze Logik, Metaphysik und Naturphilosophie bis zum Begriff der organischen Natur, der nicht ausgeführt ist.") ma tom Nachlass Hegel, Bd. 9, obejmujący: „Logik, Metaphysik, Naturphilosophie-Gliederungsentwurf zur Metaphysik - Zur System der speculativen Philosophie (Vorlesungsfragmente Jena, Sommer 1803 bis Winter 1804/1805). Znajdują się tam jednak 394 karty, ale brakuje początku (3 karty).

${ }_{84}$ Twardowski nawiązuje tutaj bezpośrednio do wykładu Hayma (zob. uwagi o reakcji Goethego i v. Humboldta). Zob. R. Haym, Hegel und seine Zeit, „Fünfte Vorlessung. Der erste Entwurf des philosophischen Systems", s. 93. Dalej Twardowski dokonuje sukcesywnie streszczenia wykładu Hayma. Wskazujemy w tym momencie tylko wybrane, naszym zdaniem, charakterystyczne dla jego wykładu miejsca. Nie oznacza to jednak, że Twardowski pozostaje mało twórczy lub cokolwiek zapożycza u Hayma. Z taką sytuacją nie mamy do czynienia nigdzie w jego wykładzie. Jest to raczej odtwórcza praca na rzecz jasnego przybliżenia meandrów trudnej filozofii Hegla. W swym wykładzie Twardowski pozostaje jak najbardziej twórczy. Nie ma w naszej literaturze zbyt wielu wykładów o filozofii Hegla. Dokonanie Twardowskiego pozostaje tym większe, że przedstawia on swoją wersję Heglowskiej fi- 
lozofii nie tylko na podstawie źródeł i kompetentnych komentarzy, lecz stara się być w pełni zrozumiały dla odbiorcy.

85 Zob. ibidem, s. 94.

${ }_{86}$ Zob. ibidem.

87 Zob. ibidem, s. 95.

88 Zob. ibidem, s. 96.

89 Zob. ibidem, „Formelle Beschaffenheit und allgemeiner Sinn dieses Systems", s. 96-97.

90 Zob. ibidem, s. 97-98.

91 Zob. ibidem, s. 99-100.

92 Zob. K. Rosenkranz, Georg Wilhelm Friedrich Hegel's Leben, „Erstes Buch. Das System", s. 101.

93 Fragment pracy o Boskim trójkącie (Fragment vom Dreieck der Dreiecke) (G. W. F. Hegel, Fragment vom Dreieck der Dreiecke, w: idem, Schriften und Entwürfe (1799-1808), hrsg. von Manfred Baum, Kurt Rainer Meist, Theodor Ebert, w: idem, Gesammelte Werke, Bd. 5, Hamburg 1998, s. 477-482), został wyróżniony w spuściźnie Hegla przez Karla Rosenkranza. Przyporządkował go do okresu frankfurckiego (zob. K. Rosenkranz, Georg Wilhelm Friedrich Hegel's Leben, s. 101-102). W tym samym roku fragment został częściowo opublikowany (część tekstu została zaś sparafrazowana) (zob. K. Rosenkranz, Hegel's ursprüngliches System. 1798-1806, Aus Hegel's Nachlaß, Literarhistorisches Taschenbuch Jg. 2, 1844, s. 154-242, zwłaszcza s. 162-164, a także H. Schneider, Anfänge der Systementwicklung Hegels in Jena, Bd. 10, 1975, „Hegel-Studien”, s. 133-171, a zwłaszcza s. 138). Oryginał tekstu nie zachował się do dziś. W przeciwieństwie do Rosenkranza, Heinz Kimmerle datował go na okres jenajski (zob. H. Kimmerle, Zur Chronologie von Hegels Jenaer Schriften, Bd. 4, 1967, „Hegel-Studien”, s. 125-176, zwłaszcza s. 144, 161-162).

94 Zob. K. Rosenkranz, Georg Wilhelm Friedrich Hegel's Leben, „Erstes Buch. Das System", s. 101-102.

95 Zob. ibidem.

96 Zob. ibidem, s. 102-103.

97 Zob. R. Haym, Hegel und seine Zeit, „Fünfte Vorlessung. „Formelle Beschaffenheit und allgemeiner Sinn dieses Systems", s. 97-98.

98 Zob. ibidem.

99 Zob. ibidem, s. 99-100.

100 Zob. K. Fischer, Geschichte der neuern Philosophie, Bd. 5: Fichte und seine Vorgänger, Heidelberg 1869, „Drittes Buch: Entwicklung der Wissenschftslehre, Drittes Capitel: Die Grundlage und die Grundsätze der Wissenschaftslehre, I: Der erste Grundsatz, 2: Das Ich als nothwendige Thathandlung (Absolutes Subject)", s. 487$-489$.

101 Zob. ibidem.

102 Zob. ibidem, „Drittes Buch. Entwicklung der Wissenschftslehre. Drittes Capitel. Die Grundlage der Wissenschafts. Die Grundsatze. Der zweite Grundsatz, „1. Die Entgegensetzung. Das Nicht-Ich”, s. 496-497, „2. Das Nicht-Ich kein Ding an sich", s. 497-498, „3. Der Begriff des Nicht-Ich", s. 498-501.

103 Zob. R. Haym, Hegel und seine Zeit, „Fünfte Vorlessung. Die Fundamentalvorstellung: das Absolute ist Geist", s. 100.

104 Zob. ibidem.

105 Zob. ibidem.

106 Zob. ibidem.

107 Zob. ibidem.

108 Zob. ibidem, s. 101. Por. K. Rosenkranz, Georg Wilhelm Friedrich Hegel's Leben, „Erstes Buch. Das System”, s. 103-104.

109 Zob. R. Haym, Hegel und seine Zeit, „Fünfte Vorlessung. Die Fundamentalvorstellung: das Absolute ist Geist", s. 101-102. Por. K. Rosenkranz, Georg Wilhelm FriedrichmmHegel's Leben, „Erstes Buch. Das System. I. Die logische Idee”, s. 104-112. 
110 Zob. R. Haym, Hegel und seine Zeit, „Fünfte Vorlessung. Die Fundamentalvorstellung: das Absolute ist Geist", s. 102. Zob. K. Rosenkranz, Georg Wilhelm Friedrich Hegel's Leben, „Erstes Buch. Das System. II. Die Natur”, s. 112-124.

111 Zob. R. Haym, Hegel und seine Zeit, „Fünfte Vorlessung. Die Fundamentalvorstellung: das Absolute ist Geist", s. 102. Por. K. Rosenkranz, Georg Wilhelm Friedrich Hegel's Leben, "Erstes Buch. Das System. III. Der Geist”, s. 124-141.

112 Zob. R. Haym, Hegel und seine Zeit, „Fünfte Vorlessung. Die Fundamentalvorstellung: das Absolute ist Geist", s. 102-103.

113 Zob. ibidem, s. 103.

114 Zob. R. Haym, Hegel und seine Zeit, „Fünfte Vorlessung. Daraus folgende dialektische Natur des Absoluten", s. 104.

115 Zob. ibidem.

116 Zob. ibidem, s. 104-105. Por. K. Rosenkranz, Georg Wilhelm Friedrich Hegel's Leben, „Erstes Buch. Das System”, s. 103-104, a także „I. Die logische Idee”, s. 107-108, 111-112.

117 Zob. R. Haym, Hegel und seine Zeit, „Fünfte Vorlessung. Specielle Gliederung und dialektischer Fortschrift des System", s. 106-107.

118 Zob. ibidem, s. 108.

119 Zob. ibidem.

120 Zob. ibidem, s. 108-109.

121 Zob. ibidem, s. 110. Dodajmy, że wykład Hayma, a także Rosenkranza, przebiega i wybiega w swoich analizach znacznie dalej od tego, co omawia w wielkim skrócie tutaj Twardowski. Na przykład u Hayma wyróżnionych zostaje jeszcze siedem osobnych działów, które wiążą proces dialektyczny i pojęcie "ducha absolutnego" w pierwszym zarysie Heglowskiego systemu z działem „Logiki” i „Metafizyki". Odbywa się to również w obszarze „Filozofii przyrody” („Naturphilosophie”), a także w obszarze samego „Ducha”.

122 Łącznie Haym wyróżnia, jak wspomnieliśmy, siedem takich działów, obok tych już wymienionych przez Twardowskiego. Najważniejszy w perspektywie wykładu Twardowskiego jest sam proces dialektyczny, uchwycenie w nim momentu spekulatywnego, a także odróżnienie sfery subiektywności i obiektywności ducha. Na plan dalszy schodzi tu natomiast relacja między logiką a metafizyką oraz analiza pojęć zawartych w dziale „Filozofii przyrody”, jak na przykład pojęcie "organizmu”, czy też „organiczności”. Twardowski kończy w tym momencie swój wykład, w jego części dotyczącej Heglowskiego „frankfurckiego zarysu systemu”, ufając że zarysowany przez niego schemat Heglowskiego procesu dialektycznego będzie wystarczający dla zrozumienia kolejnych treści.

123 Zob. List Hegla do Schellinga z 2 listopada 1800 roku, w: Briefe von und an Hegel, hrsg. von J. Hoffmeister, Bd. 1: 1785-1812 (G. W. F. Hegel, Sämtliche Werke 27; Philosophische Bibliothek 235), Hamburg 1952, s. 58-63, a zwłaszcza 60-63.

${ }_{124}$ Zob. R. Haym, Hegel und seine Zeit, „Fünfte Vorlesung. Der erste Entwurf des philosophischen Systems", s. 122-123, a także "Sechste Vorlesung. Rückblick auf den Gang der deutschen Philosophie vor Hegel. Geistigen Leben in Jena", s. 124-125.

125 Zob. R. Haym, Hegel und seine Zeit, „Sechste Vorlesung. Rückblick auf den Gang der deutschen Philosophie vor Hegel. Geistigen Leben in Jena. Stellung Hegel's zu den Ideen und der Philosophie der Zeit. Kant'sche Philosophie. Fichte'sche Philosophie. Entwicklungsgang der Schelling'schen Philosophie bis zum Identitätssystem. Sin und Werth des Letzteren", s. 124-142. Twardowski podąża w dalszym ciągu za wykładem Hayma. Jednak ten fragment jego wykładu o początkach Hegla w Jenie rozpoczyna się w kontekście i w nawiązaniu do rozważań Rosenkranza. Zob. K. Rosenkranz, Georg Wilhelm Friedrich Hegel's Leben, "Zweites Buch. Jena's literarische Situation", s. 147-148. Twardowski podąża tutaj za narracją Rosenkranza, opisując zastany stan filozofii w Jenie przed przybyciem tam Hegla.

126 Zob. K. Rosenkranz, Georg Wilhelm Friedrich Hegel's Leben, „Zweites Buch. Jena's literarische Situation", s. 147-148. 
${ }_{127}$ Zob. ibidem.

128 Zob. R. Haym, Hegel und seine Zeit, "Sechste Vorlesung. Rückblick auf den Gang der deutschen Philosophie vor Hegel. Kant'sche Philosophie", s. 128-129.

129 Zob. R. Haym, Hegel und seine Zeit, "Sechste Vorlesung. Rückblick auf den Gang der deutschen Philosophie vor Hegel. Fichte'sche Philosophie", s. 129-131.

130 Zob. ibidem.

131 Zob. R. Haym, Hegel und seine Zeit, „Sechste Vorlesung. Rückblick auf den Gang der deutschen Philosophie vor Hegel. Entwicklungsgang der Schelling'schen Philosophie bis zum Identitätssystem", s. 131-135.

${ }_{132}$ Twardowski streszcza w tym miejscu tekst Kuno Fischera (zob. K. Fischer, Geschichte der neuern Philosophie, Bd. 8: Hegels Leben, Werke und Lehre, Tl. 2, Heidelberg 1901, „Erstes Buch: Hegels Lehre, Fünfundzwanzigtes Capitel: Die Naturphilosophie. C. Die Organik, III: Der animalische Organismus, 5: Die Gattungen und die Arten des Thierreichs, s. 633), który podaje, że Jean-Baptiste Lamarck był autorem wydanej w 1809 roku pracy Philosophie zoologique, natomiast Georges Cuvier opublikował w 1812 roku Recherches sur les ossements fossiles des quadrupèdes. Twardowski w tekście wykładu przekazuje nieprawidłowy tytuł pracy Cuviera. Podaje jednocześnie daty śmierci obu zoologów (Lamarck - 1829, Cuvier - 1832), których brak u Fischera, pomija natomiast podane przez niemieckiego filozofa daty publikacji obu wymienionych dzieł.

133 Zob. R. Haym, Hegel und seine Zeit, „Sechste Vorlesung. Rückblick auf den Gang der deutschen Philosophie vor Hegel. Entwicklungsgang der Schelling'schen Philosophie bis zum Identitätssystem", s. 132.

134 Zob. ibidem, s. 133.

135 Zob. ibidem, s. 133-134.

136 Zob. ibidem.

137 Zob. ibidem, s. 134-135. W tym i poprzednim akapicie Twardowski nawiązuje za Haymem do wpływu romantyków na filozofię Schellinga. Jest to ważne oddziaływanie, którego nie mógł on pominać. Problem sztuki, poezji i jej wpływu na filozofię od czasów Schillera i Gethego był w filozofii niemieckiego idealizmu, zwłaszcza u Schellinga, stale obecny. Stanowił nie tyle punkt odniesienia dla jego rozważań, ile był momentem przełomowych, systemowych zmagań, które w tym czasie osiągnęły swoją kulminację w Systemie idealizmu transcendentalnego z 1800 roku.

${ }_{138}$ Zob. F. W. J. Schelling, System des transcendentalen Idealismus (1800), w: Friedrich Wilhelm Joseph von Schellings sämmtliche Werke, Dritter Band (1799. 1800), 1858, s. 327-635. Cyt. podajemy za F. W. J. Schelling, System idealizmu transcendentalnego, przeł. K. Krzemieniowa, tekst oprac. M. J. Siemek, Warszawa 1979, zob. zwłaszcza "Szósty rozdział główny: Dedukcja ogólnego organu filozofii, czyli podstawowe założenia filozofii sztuki według zasad idealizmu transcendentalnego", s. 348-377, a szczególnie „§3. Wnioski. Stosunek sztuki do całego systemu”, s. 363-369. Twardowskiemu chodzi tutaj dokładnie o fragment, który we współczesnym polskim wydaniu dzieła Schellinga znajduje się na s. 365: „Owa zdolność wytwórcza jest tą właśnie zdolnością, dzięki której sztuce udaje się rzecz niemożliwa, mianowicie zniesienie nieskończonego przeciwieństwa w skończonym wytworze. Tym, czym w pierwszej potencji był pierwotny ogląd, jest zdolność poetycka, i odwrotnie, tym, co nazywamy zdolnością poetycką, jest tylko powracający $\mathrm{w}$ najwyższej potencji ogląd wytwórczy. Tym, co działa w nich obu, jest jedno i to samo - jedyne, dzięki czemu jesteśmy zdolni pomyśleć i złączyć coś, co jest sprzeczne - mianowicie wyobraźnia. A zatem tym, co z tamtej strony świadomości jawi nam się jako rzeczywiste, z tej zaś jako idealne, czyli świat sztuki, są wytwory jednej i tej samej aktywności".
139 Zob. ibidem, s. 366-367.
140 Zob. ibidem, s. 367.
141 Zob. ibidem.
142 Zob. ibidem, s. 368-369. 
143 Zob. R. Haym, Hegel und seine Zeit, „Sechste Vorlesung. Rückblick auf den Gang der deutschen Philosophie vor Hegel. Entwicklungsgang der Schelling'schen Philosophie bis zum Identitätssystem", s. 140-141.

144 Zob. ibidem.

145 Zob. R. Haym, Hegel und seine Zeit, "Siebente Vorlesung. Der Anschluß an Schelling. Verhältniß des Hegel'schen zum Schelling'schen Softem nach der Seite ihrer Verwandtschaft und ihres Unterschiedes. Hegel identificirt seine mit der Schelling'schen Philosophie. Die «Differenz des Fichte'schen und Schelling'schen Philosophie». Gemeinschaftliche Lehr- und literarische Thätigkeit. Das Kritische Journal", s. 143-158. Twardowski kontynuuje swoje rozważania w ich początkowym fragmencie tylko na podstawie wykładu Hayma. Porównanie filozofii Hegla i Schellinga, dokonane w tych rozważaniach, przebiega na podstawie analiz Hayma i własnych przemyśleń. W przypadku analiz dotyczących Heglowskiego „Differenzschrift" dochodzą jeszcze, obok wykładu Hayma, rozważania Rosenkranza.

146 Komentarz Schellinga do Systemu idealizmu transcendentalnego w postaci Darstellung meines System ukazał się w 1801 roku w wydawanym przez niego "Zeitschrift für spekulative Physik", Bd. 2, H. 2, 1801, s. III-XIV, 1-127. Była to praca, jak podaje Twardowski za Haymem, pisana dość pośpiesznie, co było niewątpliwie spowodowane pojawieniem się w Jenie w 1800 roku Hegla. Schelling widział w Heglu swojego rywala i przeciwnika, z którym niejednokrotnie w przyszłości przyszło mu się zmierzyć na polu filozoficznym.

147 Zob. F. W. J. Schelling, System idealizmu transcendentalnego, zwłaszcza „Szósty rozdział główny: Dedukcja ogólnego organu filozofii, czyli podstawowe założenia filozofii sztuki według zasad idealizmu transcendentalnego. Ogólne uwagi do całego systemu", s. 369-374.

148 Przedstawiona tutaj przez Twardowskiego charakterystyka porównawcza Hegla z Schellingiem, jak już wspomnieliśmy, przebiega według rysów podanych przez Hayma w jego wykładzie. Są to odpowiednio: R. Haym, Hegel und seine Zeit, "Siebente Vorlesung. Der Anschluß an Schelling”, „Verhältniß des Hegel'schen zum Schelling'schen Softem nach der Seite ihrer Verwandtschaft und ihres Unterschiedes”, s. 144-148, oraz "Hegel identificirt seine mit der Schelling'schen Philosophie", s. 148-152. Analiza prównawcza Twardowskiego została skonstruowana w sposób perfekcyjny. Po to, aby nie zakłócać jej przebiegu zbędnymi w tym momencie komentarzami, odstępujemy od wskazywania miejsc pokrewnych z wykładem Hayma. Naszym zdaniem, jest to najlepsza analiza porównawcza, jaka kiedykolwiek powstała i została zaprezentowana w polskiej literaturze filozoficznej. Unikając zbędnych w tym względzie komentarzy, wskazujemy jedynie te miejsca, które są ważne dla wykładu Twardowskiego i które rzeczy wiście coś wnoszą do lektury Hayma. Wolne miejsca od komentarzy odnoszą się do kart oryginału między k. 55 a k. 60 .

149 Twardowski sięga tutaj do końcowych fragmentów podsumowania wykładu siódmego Hayma. Zob. R. Haym, Hegel und seine Zeit, „Siebente Vorlesung. Der Anschluß an Schelling. Das Kritische Journal", s. 157-158.

150 Wraz z przybyciem Hegla do Jeny rozpoczęła się rywalizacja między nim a Schellingiem. Była ona widoczna zarówno w stylu prowadzonych zajęć, jak i w samym podejściu do filozofii. Konflikt z czasem zaczął narastać. Jednak w tej pierwszej fazie Schelling z Heglem starali się utrzymywać dość poprawne stosunki. Zob. uwagi R. Hayma w Hegel und seine Zeit, "Siebente Vorlesung. Der Anschluß an Schelling. Die «Differenz des Fichte'schen und Schelling'schen Philosophie»", s. 152-154. Por. też rozważania K. Rosenkranza Georg Wilhelm Friedrich Hegel's Leben, "Zweites Buch. Jena's literarische Situation. Die Differenz des Ficchte'schen und Schelling'schen Systems", s. 148-151.

151 G. W. F. Hegel, Differenz des Fichteschen und Schellingschen System der Philosophie, „Vorerinnerung”, s. 9-15, „Mancherlei Formen, die bei dem jetzigen Philosophieren vorkommen”, s. 15-52, „Darstellung des Fichte Systems”, s. 52-94, „Vergle- 
ichung des Schellingschen Prinzips der Philosophie mit dem Fichteschen", s. 94-116, „Über Reinholds Ansicht der Philosophie”, s. 116-141, w: idem, Werke in zwanzig Bänden, Bd. 2, „Jenaer Schriften (1801-1807)”, ed. Suhrkamp Verlag, Frankfurt am Ma in 1971. Tuż po dokonanej w dniu swoich 31 urodzin (zob. w: Briefe von und an Hegel, hrsg. von J. Hoffmeister, Bd. 1: 1785-1812 (G. W. F. Hegel, Sämtliche Werke 27; Philosophische Bibliothek 235), Hamburg 1952, s. 445, przyp. 8) obronie habilitacji w Jenie 27 sierpnia 1801 roku (Dissertatio philosophica de orbitis planetarum) Hegel opublikował we wrześniu tego samego roku, już jako Privatdozent tamtejszego uniwersytetu, Differenz des Fichte'schen und Schelling'schen Systems der Philosophie (zob. G. W. F. Hegel, Differenz des Fichte'schen und Schelling'schen Systems der Philosophie in Beziehung auf Reinhold's Beyträge zur leichtern Übersicht des Zustands der Philosophie zu Anfang des neunzehnten Jahrhunderts 1stes Heft, Jena 1801). Została ona odebrana jako wsparcie pozycji jego przyjaciela Schellinga przeciw wpływom Fichtego, który jedynie dwa lata wcześniej został usunięty z katedry w Jenie. Publikacja książki, pierwszej większej filozoficznej monografii Hegla, dodatkowo wzmocniła jego więzy z Schellingiem. Zaczęli wspólnie wydawać „Kritisches Journal der Philosophie” (T. Pinkard, Hegel. A Biography, s. 105, 107, 109-110, 153-154, 678, przyp. 109).

${ }_{152}$ Zob. uwagi R. Hayma w Hegel und seine Zeit, "Siebente Vorlesung. Der Anschluß an Schelling. Die «Differenz des Fichte'schen und Schelling'schen Philosophie»", s. 152-154. Por. też rozważania K. Rosenkranza w Georg Wilhelm Friedrich Hegel's Leben, „Zweites Buch. Jena's literarische Situation. Die Differenz des Fichte'schen und Schelling'schen Systems", s. 148-151.

${ }_{153}$ Zob. R. Haym, Hegel und seine Zeit, "Siebente Vorlesung. Der Anschluß an Schelling. Gemeinschaftliche Lehr- und literarische Thätigkeit", s. 153.

154 Zob. ibidem, „,Siebente Vorlesung. Der Anschluß an Schelling. Das Kritische Journal", s. 154.

155 Ten przegląd jeneańskich filozofów naukowców czynnie wykładających, który podaje tutaj Twardowski, pochodzi od K. Fischer, Geschichte der neuern Philosophie, Bd. 8: Hegels Leben, Werke und Lehre, Tl. 1, Heidelberg 1901, „Erstes Buch: Hegels Leben und Werke, Sechstes Capitel: Hegel in Jena. Die ersten sechs Jahre seiner litterarischen und akademischen Wirksamkeit, III: Jenaische Zustände und Personen. 3: Philosophische Docenten", s. 66-67.

156 Dissertatio philosophica de orbitis planetarum quam rectore academiae magnificentissimo serenissimo principe ac domino Domino Carolo Augusto duce Saxoniae Iuliaci Cliviae Montium Angariae et Guestphaliae rel. consentiente amplissimo philosophorum ordine pro licentia docendi rite obtinenda publico examini submittit Ge. Wilh. Frid. Hegel philosophiae doctor, Ienae 1801.

157 Dokładne omówienie dysertacji habilitacyjnej Hegla podaje K. Rosenkranz w Georg Wilhelm Friedrich Hegel's Leben, "Zweites Buch. Jena's literarische Situation. Die Dissertation über die Planeten bahnen", s. 151-155.

${ }_{158}$ Przebieg obrony habilitacji Hegla dokładnie omawia K. Rosenkranz w Georg Wilhelm Friedrich Hegel's Leben, "Zweites Buch. Jena's literarische Situation. Habilitationsdisputation am 27 August, 1801", s. 156-159. Podane są tam tezy postawione przez Hegla i omówienie argumentacji. Zob. też G. W. F. Hegel, Habilitationsthesen 1801, w: idem, "Anhang” zu Werke in zwanzig Bänden, „Jenaer Schriften, 1801-1807”, s. 533-534.

${ }_{159}$ Hegel w Jenie wykładał najpierw od semestru zimowego 1801/1802 jako privatdocent, a później jako profesor od semestru letniego 1805 do semestru zimowego 1807/1808. Szerzej o wykładach Hegla w Jenie traktuje (podaje ich tytuły i lokalizację [miejsce, data, semestr]) K. Fischer w Geschichte der neuern Philosophie, Bd. 8: Hegels Leben, Werke und Lehre, Tl. 1, Heidelberg 1901, „Erstes Buch: Hegels Leben und Werke, Sechstes Capitel: Hegel in Jena. Die ersten sechs Jahre seiner litterarischen und akademischen Wirksamkeit, II: Akademische Wirksamkeit. 1: Vorlesungen", s. 62-63 . 
160 Zob. „Kritisches Journal der Philosophie”, 1802, 1. Bd.,1. St., 1802 (F. W. J. Schelling, Ueber das Wesen der philosophischen Kritik überhaupt, und ihr Verhältniß zum gegenwärtigen Zustand der Philosophie insbesondere, s. III - XXIV; Ueber das absolute Identitätssystem und sein Verhältniß zu dem neuesten (Reinholdischen) Dualismus, s. 1-90; Neue Entdeckung über die Fichte'sche Philosophie, s. 113-115, Ueber das Verhältniß der Naturphilosophie zur Philosophie überhaupt, s. 1-25, G. W. F. Hegel, Notizenblatt. Besonderer Zweck des Blattes, s. 116-121, poza tym liczne recenzje autorstwa Schellinga i Hegla). Zob. „Kritisches Journal der Philosophie”, 1802, 2. Bd., 1. St., 1802 (G. W. F. Hegel, Glauben und Wissen oder die Reflexionsphilosophie der Subjectivität, in der Vollständigkeit ihrer Formen, als Kantische, Jacobische, und Fichtesche Philosophie, s. 1-188; Ueber die wissenschaftlichen Behandlungsarten des Naturrechts, seine Stelle in der praktischen Philosophie, und sein Verhältniß zu den positiven Rechtswissenschaften, s. 1-34, Ueber Dante in philosophischer Beziehung, s. 35 - 50, oraz kilka recenzji autorstwa Schellinga i Hegla). Dokładne omówienie współpracy Schellinga i Hegla podaje K. Rosenkranz w Georg Wilhelm Friedrich Hegel's Leben, "Zweites Buch. Jena's literarische Situation. Kritisches Journal der Philosophie 1802-1803", s. 162-178.

161 Pismo redagowane przez Niethammera i Fichtego to: Philosophisches Journal einer Gesellschaft Teutscher Gelehrten, Bd. 1-4 1795/1796, Bd. 5-10 1797/1798 (razem z Fichtem).

162 Dziś wiemy, że argumentacja Twardowskiego nie odbiegała znacznie od rzeczywistości. Co prawda Schelling z Heglem współpracowali ze sobą w okresie jenajskim w zakresie wskazanych trzech czasopism, które razem współredagowali, ale do końca nie wiadomo komu przypisać autorstwo większości tych prac. Jedni skłaniają się ku Schellingowi, a inni ku Heglowi. Jeszcze inni przypisują autorstwo obu lub błędnie Schellingowi albo Heglowi. We wspomnianych dwóch czasopismach prowadzonych przez Schellinga ukazywały się jednak głównie prace jego autorstwa. Zob. "Zeitschrift für spekulative Physik”, Bd. 1, 1800 (F. W. J. Schelling, Anhang zu dem voranstehenden Aufsatz, betreffend zwei naturphilosophische Recensionen und die Jenaische Allgemeine Literaturzeitung, s. 49-99, Allgemeine Deduction des dynamischen Processes oder der Categorien der Physik, s. 100-136, Allgemeine Deduction des dynamischen Processes, s. 3-87). Zob. „Zeitschrift für spekulative Physik”, Bd. 2, 1801, (F. W. J. Schelling, Anhang zu dem Aufsatz des Herrn Eschenmayer betreffend den wahren Begriff der Naturphilosophie, und die richtige Art ihre Probleme aufzulösen, s. 109-146, Darstellung meines Systems der Philosophie, S. III-XIV, 1-127; Noch einiges über den Magnetismus, s. 142-148; Nachricht von neuen Entdeckungen über den Galvanismus, s. 149-152). Zob. też „Neue Zeitschrift für speculative Physik”, Bd. 1, 1802 (F. W. J. Schelling, Fernere Darstellungen aus dem System der Philosophie, s. 1-77; Grundzüge zu einer Darstellung des Begriffs der Physik und der Verhältnisse dieser Wissenschaft zur gegenwärtigen Lage der Naturkunde, s. 78-160; Benehmen des Obscurantismus gegen die Naturphilosophie, s. 161188; Der Ferneren Darstellungen aus dem System der Philosophie Andrer Theil, s. 1-181). O relacjach i współpracy w ramach wskazanych czasopism traktuje K. Rosenkranz w Georg Wilhelm Friedrich Hegel's Leben, "Zweites Buch. Jena's literarische Situation. Kritisches Journal der Philosophie 1802-1803", s. 162-178.

163 Zob. uwagi R. Hayma w Hegel und seine Zeit, „Achte Vorlesung. Fortsetzung. Vollendung des Systementwurfs unter Schelling'schem Einfluß, oder das System der Sittlichkeit. Zussamenhang der Hegel'schen Ethik als des Schlußgliedes seines Systems mit bessen früher entworfenen Theilen. Classische Grundlage dieser Ethik und Verhältniß ihrer Auffassung vom Staat zu dem Staatsbegriff in Hegel's Kritik der deutschen Verfassung. Schellingisirende Züge der Ethik, namentlich in Beziehung auf Form und Methode. Gliederung und Inhalt des Systems der Sittlichkeit", s. 159-179. Ta faza wykładu Twardowskiego została oparta ponownie na wskazanych rozważaniach Hayma.

${ }^{164}$ Heglowski System der Sittlichkeit uznawany jest za fragment dopełniający systemowe badania Hegla w okresie frankfurckim. Powstał najprawdopodobniej na przełomie 1802/1803 jako dopełnienie Heglowskich wykładów akademickich. Czę- 
sto łączy się go i sytuuje w odniesieniu do ustaleń Fichtego. W ten sposób dodaje się do pierwotnego tytułu podtytuł Critik des Fichteschen Naturrechts. W literaturze przedmiotu często uznawany jest za dzieło dopełniające zarys systemu frankfurckiego, jako jego trzecia część. Dzieło Hegla jest ściśle powiązane z innymi jego pracami z okresu jenajskiego: Über die wissenschaftlichen Behandlungsarten des Naturrecht, seine Stelle in der praktischen Philosophie, und sein Verhältnis zu den positiven Rechtswissenschaften (1802), Deutschlands Verfassung (1803) und die Realphilosophie (1805/06). Bez tych prac ten tekst Hegla jest trudny do zrozumienia. Hegel swój tekst rozpisał w trzech rozdziałach. Były to: 1 . Die absolute Sittlichkeit nach dem Verhältnis, s. 421-460, A. Erste Potenz der Natur, Subsumtion des Begriffs unter die Anschauung 421-436, B. Zweite Potenz der Unendlichkeit, Idealität, im Formellen, oder in dem Verhältnis, s. 436-460, 2. Das Negative oder die Freiheit oder das Verbrechen, s. 450-464, 3. Sittlichkeit, s. 464-603, Erster Abschnitt: Die Staatsverfassung. I. Die Sittlichkeit als System, ruhend, s. 468-480, II. Regierung, s. 480-503, A. Die absolute Regierung, s. 482-488, B. Allgemeine Regierung, s. 488-503, A. Das System des Bedürfnisses, s. 492-498, B. Das System der Gerechtigkeit, s. 499-501, C. Das System der Zucht, s. 501-503 (rozpisane za ed. Lassona). System der Sittlichkeit, jak zaznaczyliśmy, powstał w Jenie zimą z 1802 na 1803 rok lub wiosną 1803 roku (Zob. H. Kimmerle, Zur Chronologie von Hegels Jenaer Schriften, Nr. 4 (1967), „Hegel-Studien”, s. 125-176, zwłaszcza s. 154). Tytuł nie pochodzi od Hegla i został tekstowi nadany przez Karla Rosenkranza, który jako pierwszy publicznie omówił treść manuskryptu (zob. St. Schmidt, Hegels „System der Sittlichkeit”, (Hegel-Forschungen) Berlin 2007, s. 12). Tekst nie został opublikowany za życia autora. Po jego śmierci był wykorzystywany w rękopisie zarówno przez Rosenkranza, jak i przez Hayma. System der Sittlichkeit został opublikowany po raz pierwszy przez Georga Mollata (18631947) (zob. H. Bernert, Georg Mollat, „Zeitschrift des Vereins für hessische Geschichte und Landeskunde", Bd. 102 (1997), s. 141, 147) w 1893 roku. Publikacja nastąiłiła więc już w cztery lata po przekazaniu spuścizny Hegla przez jego synów do zbiorów Biblioteki Królewskiej w Berlinie (zob. E. Ziesche, Der handschriftliche Nachlaß, Tl. 1, s. 8, 11). Przy czym Mollat miał swobodny dostęp do rękopisu w swoim rodzinnym mieście, gdyż udało mu się nawet uzyskać zgodę na przewiezienie rękopisu na okres prac nad wydaniem do Biblioteki Murchardów w Kassel (ibidem, s. 11). Edycja ta jest niekompletna i nosi ślady wielu nieuprawnionych ingerencji wydawcy (G. W. F. Hegel, System der Sittlichkeit, Aus dem handschriftlichen Nachlasse des Verfassers herausgegeben von G. Mollat, Osterwieck/Harz 1892, s. nienumerowana; Hegels Schriften zur Politik und Rechtsphilosophie, hrsg. von Georg Lasson, (Philosophische Bibliothek 133; Georg Wilhelm Friedrich Hegel, Sämtliche Werke 7) Leipzig 1913, s. 419-503, „Vorwort”, s. 504-505). Wydanie pełne zostało opublikowane przez Georga Lassona dwadzieścia lat po Mollacie, w 1913 roku (Hegels Schriften zur Politik und Rechtsphilosophie, hrsg. von Georg Lasson (Philosophische Bibliothek 133; Georg Wilhelm Friedrich Hegel, Sämtliche Werke 7), Leipzig 1913, s. 419-503). Obecnie dysponujemy także nową edycją z 1998 roku (G. W. F. Hegel, System der Sittlichkeit. Reinschriftenwurf, w: idem, Schriften und Entwürfe (1799-1808), hrsg. von M. Baum und K. R. Meist, Th. Ebert (Georg Wilhelm Friedrich Hegel, Gesammelte Werke 5), Hamburg 1998, s. 277-361).

165 Zob. K. Fischer, w Geschichte der neuern Philosophie, Bd. 8: Hegels Leben, Werke und Lehre, Tl. 1, Heidelberg 1901, „Erstes Buch: Hegels Leben und Werke, Sechstes Capitel: Hegel in Jena. Die ersten sechs Jahre seiner litterarischen und akademischen Wirksamkeit, II: Akademische Wirksamkeit. 1: Vorlesungen”, s. 63 („2. Sommer 1802: G. W. F. H. Logicam et Metaphysicam sive systema reflexionis et rationis secundum librum sub eodem titulo proditurum, h. V-VI, deinde jus naturae, civitatis et gentium ex dictatis, h. III-IV tradet").

166 Zob. K. Fischer, Geschichte der neuern Philosophie, Bd. 8: Hegels Leben, Werke und Lehre, T1. 1, Heidelberg 1901, „Erstes Buch: Hegels Leben und Werke, Sechstes Capitel: Hegel in Jena. Die ersten sechs Jahre seiner litterarischen und akademi- 
schen Wirksamkeit, II: Akademische Wirksamkeit. 1: Vorlesungen”, s. 63 („,3. Winter 1802/1803: G. W. F. H. 1) Logicam et Metaphysicam secundum librum nundinis instantibus proditurum h. VI-VII; 2) jus naturae ex dictatis h. X-XI tradet").

167 Hegel zanim osiadł we Frankfurcie, spędził krótki czas w swoim rodzinnym mieście - Stuttgarcie w Wirtembergii, gdzie wśród interwencji wojsk francuskich i austriackich toczyła się polityczna walka o przyszły ustrój tego kraju (zakończona ostatecznie utwierdzeniem monarchii przy poparciu francuskim). Spory publicystyczne, które wówczas się toczyły, skłoniły Hegla do napisania (już po przybyciu do Frankfurtu) tekstu wspierającego przemiany demokratyczne. Praca ta powstała latem 1798 roku (przed 7 sierpnia). Znana jest pod tytułem Über die neusten inneren Verhältnisse Württembergs, besonders über die Gebrechen der Magistratsverfassung. Nie jest to jednak tytuł nadany przez autora. Hegel zatytułował ją Daß die Magistrate von den Bürgern gewählt werden müssen. Lektura tekstu została dokonana przez trzech stuttgardzkich znajomych przyszłego filozofa. Skłonili oni go do pozostawienia pracy jedynie w rękopisie. Hegel postąpił zgodnie z radami, zamiast tego opublikował anonimowo tłumaczenie pracy Carta o regionie (późniejszym kantonie) Vaud (zob. T. Pinkard, Hegel. A Biography, s. 73-76; G. Schüler, Zur Chronologie von Hegels Jugendschriften, „Hegel-Studien”, Nr. 2 (1963), s. 111-159, zwłaszcza s. 132, 148; E. Ziesche, Der handschriftliche Nachlaß, Tl. 1, s. 141).

168 Zob. R. Hayma w Hegel und seine Zeit, „Achte Vorlesung. Fortsetzung. Vollendung des Systementwurfs unter Schelling'schem Einfluß, oder das System der Sittlichkeit. Zussamenhang der Hegel'schen Ethik als des Schlußglides seines Systems mit bessen früher entworsenen Theilen", s. 160-161.

169 Zob. ibidem, s. 161.

170 Przytoczony tu przez Twardowskiego fragment z Heglowskiego System der Sittlichkeit, jak i dalsze nawiązania do Kanta, pochodzą z bezpośredniego odwołania do R. Hayma, Hegel und seine Zeit, „Achte Vorlesung. Fortsetzung. Vollendung des Systementwurfs unter Schelling'schem Einfluß, oder das System der Sittlichkeit. Zussamenhang der Hegel'schen Ethik als des Schlußglides seines Systems mit bessen früher entworsenen Theilen", s. 164.

171 Zob. ibidem.

172 Twardowskiemu chodzi tu niewątpliwie o kolejne wykłady Hegla z semestru zimowego 1803/1804 i semestru letniego 1804, a także z semestru letniego, gdzie wykładał już jako profesor. Wszystkie te wykłady były kontynuacją wcześniejszych, wskazanych już prelekcji, ich uzupełnieniem i rozwinięciem. Szerzej o nich pisze i wskazuje na nie K. Fischer w Geschichte der neuern Philosophie, Bd. 8: Hegels Leben, Werke und Lehre, Tl. 1, Heidelberg 1901, „Erstes Buch: Hegels Leben und Werke, Sechstes Capitel: Hegel in Jena. Die ersten sechs Jahre seiner litterarischen und akademischen Wirksamkeit, II: Akademische Wirksamkeit. 1: Vorlesungen", s. 63. Trzeba też wspomnieć o publikowanej w „Kritisches Journal der Philosophie”, 1802, 2. Bd., 1.St., 1802, Glauben und Wissen oder die Reflexionsphilosophie der Subjectivität, in der Vollständigkeit ihrer Formen, als Kantische, Jacobische, und Fichtesche Philosophie, s. 1-188.

173 Zob. uwagi R. Hayma w Hegel und seine Zeit, „Achte Vorlesung. Fortsetzung. Vollendung des Systementwurfs unter Schelling'schem Einfluß, oder das System der Sittlichkeit. Zussamenhang der Hegel'schen Ethik als des Schlußglides seines Systems mit bessen früher entworsenen Theilen", s. 164-165.

174 Zob. ibidem, s. 165. Przywoływany tu cytat z Heglowskiego System der Sittlichkeit, podobnie jak wcześniej, podawany jest przez Twardowskiego za wykładem Hayma.

175 Zob. uwagi R. Hayma w Hegel und seine Zeit, „Achte Vorlesung. Fortsetzung. Vollendung des Systementwurfs unter Schelling'schem Einfluß, oder das System der Sittlichkeit. Classische Grundlage dieser Ethik und Verhältnis ihrer Auffassung von Staat zu dem Staatsbegriff in Hegel's Kritik der deutschen Verfassung", s. 166-167.

176 Zob. uwagi R. Hayma w Hegel und seine Zeit, „Achte Vorlesung. Fortsetzung. Vollendung des Systementwurfs unter Schelling'schem Einfluß, oder das System der 
Sittlichkeit. Schellingisirende Züge der Ethik, namentlich in Beziehung auf Form und Methode Gliederung und Inhalt des Systems der Sittlichkeit", s. 170-171.

177 Zob. ibidem, s. 172.

178 Zob. ibidem, s. 174-175.

179 Zob. ibidem, s. 175-176.

180 Zob. ibidem, s. 176-179.

181 Zob. uwagi R. Hayma w Hegel und seine Zeit, „Neunte Vorlesung. Die Auseinandersetzung mit der Reflexionsphilosophie. Der Aufsatz über die Behandlungsarten des Naturrechts. Die Kritiken im Kritischen Journal. Formeller Standpunkt derselben: die absolute Erkenntniß. Ablehnung der Beweises für den absoluten Standpunkts. Pseudobeweise für denselben. Realer Gehalt der Hegel'schen Kritiken. Historische Construction des absoluten Idealismus. Gehalt dieser Selbstconstruction und daraus folgende Fehlurtheile", s. 180-208. U Twardowskiego następuje tutaj kontynuacja rozważań za wykładem Hayma.

${ }_{182}$ Zob. ibidem, „Neunte Vorlesung. Die Auseinandersetzung mit der Reflexionsphilosophie", s. 180.

${ }_{183}$ Zob. G. W. F. Hegel, Ueber die wissenschaftlichen Behandlungsarten des Naturrechts, seine Stelle in der praktischen Philosophie, und sein Verhältniß zu den positiven Rechtswissenschaften, w: „Kritisches Journal der Philosophie”, 1802, 2. Bd., 2. St., 1802, s. 1-88 oraz 2. Bd., 3. St., 1802, s. 1-34. Tekst ten nie zawierał pierwotnie konkretnego podziału. Występuje on dopiero w edycji Lassona, na którą powołujemy się w dalszym ciągu naszego opracowania. Tu zaznaczmy jedynie, że podział ten przebiega według treści dzieła Hegla i odnosi się bezpośrednio do: G. W. F. Hegel, Ueber die wissenschaftlichen Behandlungsarten des Naturrechts, seine Stelle in der praktischen Philosophie, und sein Verhältniß zu den positiven Rechtswissenschaften, I. Die empirische Behandlungsart, s. 334-346, II. Die formelle Behandlungsart, s. 346-371, III. Die absolute Sittlichkeit, s. 371-396, IV. Das Verhältnis des Naturrechts zu den positiven Rechtswissenschaften, s. 397-416, w: Hegels Schriften zur Politik und Rechtsphilosophie, hrsg. v. Georg Lasson, (Philosophische Bibliothek 133; Georg Wilhelm Friedrich Hegel, Sämtliche Werke 7), Leipzig 1913.

${ }_{184}$ Twardowski podąża tutaj za wykładem R. Hayma w Hegel und seine Zeit, „Neunte Vorlesung. Die Auseinandersetzung mit der Reflexionsphilosophie. Der Aufsatz über die Behandlungsarten des Naturrechts", s. 181. Zob. G. W. F. Hegel, Ueber die wissenschaftlichen Behandlungsarten des Naturrechts, seine Stelle in der praktischen Philosophie, und sein Verhältniß zu den positiven Rechtswissenschaften, I. Die empirische Behandlungsart, s. 334-346, w: Hegels Schriften zur Politik und Rechtsphilosophie, hrsg. v. Georg Lasson (Philosophische Bibliothek 133; Georg Wilhelm Friedrich Hegel, Sämtliche Werke 7), Leipzig 1913.

185 Zob. uwagi R. Hayma w Hegel und seine Zeit, „Neunte Vorlesung. Die Auseinandersetzung mit der Reflexionsphilosophie. Der Aufsatz über die Behandlungsarten des Naturrechts", s. 181. Por. G. W. F. Hegel, Ueber die wissenschaftlichen Behandlungsarten des Naturrechts, seine Stelle in der praktischen Philosophie, und sein Verhältniß $z u$ den positiven Rechtswissenschaften, II. Die formelle Behandlungsart, s. 346-371, w: Hegels Schriften zur Politik und Rechtsphilosophie, hrsg. v. Georg Lasson (Philosophische Bibliothek 133; Georg Wilhelm Friedrich Hegel, Sämtliche Werke 7), Leipzig 1913.

186 Zob. uwagi R. Hayma w Hegel und seine Zeit, „Neunte Vorlesung. Die Auseinandersetzung mit der Reflexionsphilosophie. Der Aufsatz über die Behandlungsarten des Naturrechts", s. 181. G. W. F. Hegel, Ueber die wissenschaftlichen Behandlungsarten des Naturrechts, seine Stelle in der praktischen Philosophie, und sein Verhältniß zu den positiven Rechtswissenschaften, III. Die absolute Sittlichkeit, s. 371-396, w: Hegels Schriften zur Politik und Rechtsphilosophie, hrsg. v. Georg Lasson (Philosophische Bibliothek 133; Georg Wilhelm Friedrich Hegel, Sämtliche Werke 7), Leipzig 1913.

187 Por. G. W. F. Hegel, Ueber die wissenschaftlichen Behandlungsarten des Naturrechts, seine Stelle in der praktischen Philosophie, und sein Verhältniß zu den positiven 
Rechtswissenschaften, III. Die absolute Sittlichkeit, s. 371-396, w: Hegels Schriften zur Politik und Rechtsphilosophie, hrsg. v. Georg Lasson (Philosophische Bibliothek 133; Georg Wilhelm Friedrich Hegel, Sämtliche Werke 7), Leipzig 1913.

188 Zob. ibidem. Zob. też uwagi R. Hayma w Hegel und seine Zeit, „Neunte Vorlesung. Die Auseinandersetzung mit der Reflexionsphilosophie. Formeller Standpunkt derselben: die absolute Erkenntniß", s. 186-188.

189 G. W. F. Hegel, Ueber die wissenschaftlichen Behandlungsarten des Naturrechts, seine Stelle in der praktischen Philosophie, und sein Verhältniß zu den positiven Rechtswissenschaften, IV. Das Verhältnis des Naturrechts zu den positiven Rechtswissenschaften, s. 397-416, w: Hegels Schriften zur Politik und Rechtsphilosophie, hrsg. v. Georg Lasson (Philosophische Bibliothek 133; Georg Wilhelm Friedrich Hegel, Sämtliche Werke 7), Leipzig 1913. Zob. też uwagi R. Hayma w Hegel und seine Zeit, „Neunte Vorlesung. Die Auseinandersetzung mit der Reflexionsphilosophie. Der Aufsatz über die Behandlungsarten des Naturrechts. Historische Construction des absoluten Idealismus", s. 200-206.

190 Zob. ibidem. Zob. też uwagi R. Hayma w Hegel und seine Zeit, „Neunte Vorlesung. Die Auseinandersetzung mit der Reflexionsphilosophie. Der Aufsatz über die Behandlungsarten des Naturrechts. Historische Construction des absoluten Idealismus", s. 204-206.

191 Zob. uwagi R. Hayma w Hegel und seine Zeit, „Neunte Vorlesung. Die Auseinandersetzung mit der Reflexionsphilosophie. Der Aufsatz über die Behandlungsarten des Naturrechts", s. 182.

192 Zob. ibidem. Por. G. W. F. Hegel, Ueber die wissenschaftlichen Behandlungsarten des Naturrechts, seine Stelle in der praktischen Philosophie, und sein Verhältniß zu den positiven Rechtswissenschaften, IV. Das Verhältnis des Naturrechts zu den positiven Rechtswissenschaften, s. 397-416, w: Hegels Schriften zur Politik und Rechtsphilosophie, hrsg. v. Georg Lasson (Philosophische Bibliothek 133; Georg Wilhelm Friedrich Hegel, Sämtliche Werke 7), Leipzig 1913.

193 G. W. F. Hegel, Glauben und Wissen oder die Reflexionsphilosophie der Subiectivität in der Vollständigkeit ihrer Formen als Kantische, Jakobische und Fichtesche Philosophie, „Kritisches Journal der Philosophie”, 1802, 2. Bd., 1. St., 1802, s. 1-188.

194 Zob. Heglowskie Wie der gemeine Menschenverstand die Philosophie nehme, - dargestellt an den Werken des Herrn Krug's (tak brzmiał pierwotny tytuł). Była to polemika z rówieśnikiem Hegla, Wilhelmem Traugottem Krugem. W momencie opublikowania tekstu (styczeń 1802 roku) Krug był profesorem nadzwyczajnym we Frankfurcie nad Odrą, trzy lata później przejął po śmierci Kanta katedrę w Królewcu (zob. W. Röd, Die Philosophie der Neuzeit 3, Tl. 1: Kritische Philosophie von Kant bis Schopenhauer, (Geschichte der Philosophie 9.1) München 2006, s. 158). Praca Hegla ukazała się pierwotnie w „Kritisches Journal der Philosophie”, 1802, 1. Bd., 1. St., 1802, s. 91-115. Hegel ustosunkował się tam do trzech tekstów Kruga z okresu 1800-1801: Briefe über die Wissenschaftslehre, Briefe über den neuesten Idealismus oraz Entwurf eines neuen Organons der Philosophie. Ostatnia z wymienionych prac została także zrecenzowana przez filozofa w Krugs Entwurf eines neuen Organons der Philosophie, „Erlanger Litteratur-Zeitung" 1802, Anzeigenblatt, nr 22 (4 czerwca 1802) (zob. G. Lasson, Hegels Mitarbeit an der Erlanger Litteraturzeitung, w: idem, Beiträge zur Hegel-Forschung, Berlin 1909, s. 7-42, s. 7, 11; B. Bowman, Die Schreibfeder-Kontroverse. Zu Hegels Auseinandersetzung mit W. T. Krug im "Kritischen Journal der Philosophie" und ihrem Hintergrund bei Schelling, w: Gegen das "unphilosophische Unwesen”. Das "Kritische Journal der Philosophie" von Schelling und Hegel, hrsg. von Klaus Vieweg (= Kritisches Jahrbuch der Philosophie 7), Würzburg 2002, s. 131-146, s. 132). Pełna satyry polemika Hegla opublikowana w „Kritisches Journal der Philosophie” spotkała się z repliką Kruga, pisaną pod zabawnym pseudonimem „Zettel und Squenz, Bücherverleihern zu Buxtehude", a noszącą tytuł Wie der ungemeine Menschenverstand die Philosophie nehme; an dem kritisch-philosophischen Journale der Herren Schelling und Hegel (zob. ibidem, s. 132). Wymowa tego dzieła kontynuowała ton nadany uprzednio przez He- 
gla, o czym świadczy przyjęte przez Kruga motto: „Difficile est, satyram non scribere” („Zettel und Squenz, Bücherverleihern zu Buxtehude” [tj. W. T. Krug], Wie der ungemeine Menschenverstand die Philosophie nehme; an dem kritisch-philosophischen Journale der Herren Schelling und Hegel, [Meißen] 1802, s. 1]). Hegel do polemiki z Krugem nawiązywał w późniejszych latach w Fenomenologii ducha i Encyklopedii nauk filozoficznych (zob. B. Bowman, Sinnliche Gewißheit. Zur systematischen Vorgeschichte des deutschen Idealismus (Hegel-Forschungen), Berlin 2003, s. 45). Ze swojej strony Krug występował przeciw zmarłemu już Heglowi jeszcze w 1835 roku w pracy Schelling und Hegel. Oder die neueste Philosophie im Vernichtungskriege mit sich selbst begriffen. Ein Beitrag zur Geschichte der Philosophie des 19. Jahrhunderts" (zob. B. Bowman, Die Schreibfeder-Kontroverse, s. 133).

195 Pracę tę, jak słusznie zaznacza Twardowski, należy przypisać Schellingowi. Zob. F. W. J. Schelling, Rückert und Weiß oder die Philosophie, zu der es keines Denkens und Wissens bedarf, „Kritisches Journal der Philosophie”, 1802, 1. Bd., 1. St., 1802, s. $75-112$.

196 Ta analiza postępuje u Twardowskiego w dalszym ciągu za wykładem Hayma. Zob. uwagi R. Hayma w Hegel und seine Zeit, „Neunte Vorlesung. Die Auseinandersetzung mit der Reflexionsphilosophie. Realer Gehalt der Hegel'schen Kritiken, s. 195-200, Historische Construction des absoluten Idealismus, s. 200-205, Gehalt dieser Selbstconstruction und daraus folgende Fehlurtheile", s. 205-208.

197 Zob. R. Haym, Hegel und seine Zeit, "Neunte Vorlesung. Die Auseinandersetzung mit der Reflexionsphilosophie. Realer Gehalt der Hegel'schen Kritiken", s. 198-199.

198 Zob. ibidem, s. 199-200.

199 Zob. R. Haym, Hegel und seine Zeit, „Neunte Vorlesung. Die Auseinandersetzung mit der Reflexionsphilosophie. Formeller Standpunkt derselben: die absolute Erkenntniß", s. 187-188.

200 Zob. R. Haym, Hegel und seine Zeit, „Neunte Vorlesung. Der Aufsatz über die Behandlungsarten des Naturrechts. Ablehnung der Beweises für den absoluten Standpunkts", s. 189-190.

201 Zob. ibidem.

${ }^{202}$ Zob. ibidem.

${ }^{203}$ Zob. ibidem.

204 Zob. uwagi R. Hayma w Hegel und seine Zeit, „Neunte Vorlesung. Die Auseinandersetzung mit der Reflexionsphilosophie. Ablehnung der Beweises für den absoluten Standpunkts", s. 191.

205 Zob. ibidem, s. 191-192.

206 Zob. ibidem, s. 192-193.

207 Zob. uwagi R. Hayma w Hegel und seine Zeit, „Neunte Vorlesung. Die Auseinandersetzung mit der Reflexionsphilosophie. Realer Gehalt der Hegel'schen Kritiken", s. 199.

${ }^{208}$ Zob. ibidem, s. 199-200.

209 Zob. uwagi R. Hayma w Hegel und seine Zeit, „Neunte Vorlesung. Die Auseinandersetzung mit der Reflexionsphilosophie. Historische Construction des absoluten Idealismus", s. 201.

210 Zob. ibidem, s. 202-204.

211 Zob. uwagi R. Hayma w Hegel und seine Zeit, „Neunte Vorlesung. Die Auseinandersetzung mit der Reflexionsphilosophie. Historische Construction des absoluten Idealismus", s. 204.

${ }^{212}$ Zob. ibidem, s. 205.

${ }_{213}$ Zob. ibidem.

214 Zob. ibidem, s. 205-206.

215 Zob. ibidem, s. 206.

216 Zob. ibidem, s. 207-208. 
217 Zob. uwagi R. Hayma w Hegel und seine Zeit, "Zehnte Vorlesung. Die Lossagung von Schelling und der Romantik. Schicksal der Philosophie der Romantik. Trennung von Schelling und allmälige Verselbständigung Hegel's. Vorlesungen seit 1803. Die Vorrede zur Phänomenologie. Polemik gegen die Methodelosigkeit. Historische Construction des antiromantischen Standpunkts. Neue Formulirung des Princips und der Methode. Aristotelische Züge in dieser Formulirung. Kritischer Rück- und Vorbild", s. 209-231. Rozbrat z Schellingiem, a także przejście ku Fenomenologii ducha Twardowski ujmuje i przedstawia na podstawie lektury wykładów Hayma, rozważań Fischera, a także sięga do Rosenkranza. Ta część wykładu jest jednak przede wszystkim płynnym przedstawieniem jenajskiej postaci systemu Hegla za Haymem. Po różnych odniesieniach do Kanta, Fichtego, Schellinga, romantyków, następuje tutaj charakterystyka bezpośrednich powodów odejścia od "starych systemów", w tym przede wszystkim od Schellinga. Nowa perspektywa to możliwość wyrażenia systemu w postaci Fenomenologii ducha. Twardowski podąża za Haymem, a jednocześnie stara się czytać Fenomenologię ducha. Pojawiające się w jego wykładzie cytaty z Hegla pochodzą w większości przypadków z Hayma, co nie otwiera przed nim możliwości korzystania z oryginału Hegla. W naszym komentarzu sięgamy zatem w tym przypadku zarówno do Hayma, jak i do samego Hegla.

${ }_{218}$ Zob. K. Fischer, Geschichte der neuern Philosophie, Bd. 6: Friedrich Wilhelm Joseph Schelling, Erstes Buch: Schellings Leben und Schriften, Heidelberg 1872 „Fünftes Capitel: Karoline Schlegel”, s. 56-68, a także „Sechstes Capitel: Karolinens Verbindung mit Schelling", s. 68-84.

219 Zob. „Sommer 1804: G.W.F.H., Philosophiae systema universum ita tractabit, ut aliis lectionibus Logicam et Metaphysicam et philosophiam mentis, aliis philosophiam naturae doceat". Zob. K. Fischer, Geschichte der neuern Philosophie, Bd. 8: Hegels Leben, Werke und Lehre, Tl. 1, Heidelberg 1901, „Erstes Buch: Hegels Leben und Werke, Sechstes Capitel: Hegel in Jena. Die ersten sechs Jahre seiner litterarischen und akademischen Wirksamkeit, II: Akademische Wirksamkeit. 1: Vorlesungen", s. 63.

${ }^{220}$ Zob. „Sommer 1805: G.W.F.H., Totam philosophiae scientiam. i. e. a) philosophiam speculativam (Logicam et Metaphysicam), naturae et mentis ex libro per aestatem prodituro h. VI-VII vespertina, b) jus naturae ex eodem h. IV-V tradet". Zob. K. Fischer, Geschichte der neuern Philosophie, Bd. 8: Hegels Leben, Werke und Lehre, Tl. 1, Heidelberg 1901, „Erstes Buch: Hegels Leben und Werke, Sechstes Capitel: Hegel in Jena. Die ersten sechs Jahre seiner litterarischen und akademischen Wirksamkeit, II: Akademische Wirksamkeit. 1: Vorlesungen", s. 63.

${ }^{221}$ Twardowski nawiązuje tutaj do systemu budowanego przez Hegla w okresach berneńskim, frankfurckim i jenajskim. W każdym z nich przybierał on różną formę i był sukcesywnie modyfikowany. W ostatniej postaci chodzi oczywiście o $\mathrm{Fe}$ nomenologię ducha jako pierwszą jego część. Zob. G. W. F. Hegel, System der Wissenschaft, Tl. 1: Die Phänomenologie des Geistes, Bamberg-Würzburg 1807. Dalej podajemy też odniesienia do polskiego przekładu Fenomenologii ducha, przeł. A. Landman, Warszawa 1963. W 1805 roku Hegel został mianowany profesorem nadzwyczajnym w Jenie, lecz jego finansowa sytuacja nie polepszyła się (dopiero po roku zaczął otrzymywać niewielką pensję), ponieważ spadek po ojcu się wyczerpał, musiał się zadłużać. Potrzebował lepszej posady na innym uniwersytecie. By ją otrzymać, musiał opublikować książkę, która wzmocniłaby jego pozycję. Udało mu się zawrzeć umowę z wydawcą Göbhardtem w Bambergu, jednak to finansowe poręczenie ze strony przyjaciela i protektora - Immanuela Niethammera - umożliwiło dokończenie procesu wydawniczego. Dzieło rozrastało się znacznie w stosunku do planowanych na początku rozmiarów i Hegel ostatecznie (choć jedynie kilka dni) przekroczył wyznaczony w umowie termin dostarczenia całości rękopisu (18 października 1806 roku). W trakcie pisania ostatnich partii Fenomenologii ducha pod Jeną, gdzie Hegel mieszkał i wykładał, toczyła się bitwa pomiędzy wojskami francuskimi i pruskimi (sam filozof pisał, że w dniu poprzedzającym starcie widział Napoleona przejeżdżającego przez ulice zajętego przez Francuzów miasta). To dało asumpt do pięk- 
nej, ale nieprawdziwej opowieści o Heglu piszącym ostatnią linię Fenomenologii wśród odgłosów toczącej się w pobliżu wielkiej bitwy. W rzeczywistości tekst był w późniejszym czasie przerabiany. Gdy Hegel przyjął posadę redaktora „Bamberger Zeitung", jednym z powodów wyboru tej właśnie pracy była nadzieja na sprawniejszą współpracę z bamberskim wydawcą Fenomenologii. Hegel do końca nie był pewien, jaki tytuł tekst będzie nosił. Ostatecznie książka wyszła w kwietniu 1807 roku jako Die Phänomenologie des Geistes, pierwszy tom publikacji System der Wissenschaft. Dzieło początkowo odbierane było jako głos stronnika Schellinga, jednakże dzięki lekturze tekstu oraz recenzjom w ciągu kilku lat ugruntowała się opinia o Heglu jako samodzielnym przedstawicielu niemieckiego idealizmu. (zob. T. Pinkard, Hegel. A Biography, s. 203, 223, 227-230, 232, 240, 264-265).

222 Zob. K. Fischer, Geschichte der neuern Philosophie, Bd. 8: Hegels Leben, Werke und Lehre, T1. 1, Heidelberg 1901, „Erstes Buch: Hegels Leben und Werke, Sechstes Capitel: Hegel in Jena. Die ersten sechs Jahre seiner litterarischen und akademischen Wirksamkeit, IV: Die Phänomenologie und die Schlacht. 1: Das Werk und der Streit mit dem Verleger", s. 68-69.

${ }_{223}$ Zob. ibidem, „2: Die Schlacht bei Jena”, s. 69-70.

224 Zob. List Hegla do Niethammera z 8 października 1806 roku, w: Briefe von und an Hegel, hrsg. von J. Hoffmeister, Bd. 1: 1785-1812 (G. W. F. Hegel, Sämtliche Werke 27; Philosophische Bibliothek 235), Hamburg 1952, s. 118-119.

225 Zob. List Hegla do Schellinga z 1 maja 1807 roku, w: Briefe von und an Hegel, hrsg. von J. Hoffmeister, Bd. 1: 1785-1812 (G. W. F. Hegel, Sämtliche Werke 27; Philosophische Bibliothek 235), Hamburg 1952, s. 159-162.

${ }_{226}$ Zob. K. Fischer, Geschichte der neuern Philosophie, Bd. 8: Hegels Leben, Werke und Lehre, Tl. 1, Heidelberg 1901, „Erstes Buch: Hegels Leben und Werke, Sechstes Capitel: Hegel in Jena. Die ersten sechs Jahre seiner litterarischen und akademischen Wirksamkeit, IV: Die Phänomenologie und die Schlacht. 2: Die Schlacht bei Jena", s. 70.

${ }_{227}$ Zob. G. W. F. Hegel, System der Wissenschaft, Tl. 1: Die Phänomenologie des Geistes, s. I-XCI. Zob. też Przedmowę do Fenomenologii ducha, s. 3-90.

${ }_{228}$ Zob. R. Haym, Hegel und seine Zeit, "Zehnte Vorlesung. Die Lossagung von Schelling und der Romantik. Die Vorrede zur Phänomenologie”, s. 215.

${ }_{229}$ Zob. G. W. F. Hegel, System der Wissenschaft, Tl. 1: Die Phänomenologie des Geistes, s. LXXXV. Zob. też Przedmowę do Fenomenologii ducha, s. 85.

${ }^{230}$ Zob. ibidem.

${ }^{231}$ Zob. G. W. F. Hegel, System der Wissenschaft, Tl. 1: Die Phänomenologie des Geistes, s. IX. Zob. też Przedmowe do Fenomenologii ducha, s. 15.

${ }^{232}$ Zob. G. W. F. Hegel, System der Wissenschaft, Tl. 1: Die Phänomenologie des Geistes, s. VII. Zob. też Przedmowę do Fenomenologii ducha, s. 12.

${ }_{233}$ Zob. G. W. F. Hegel, System der Wissenschaft, Tl. 1: Die Phänomenologie des Geistes, s. XXXVII-XXXVIII. Zob. też Przedmowę do Fenomenologii ducha, s. 42-43.

${ }^{234}$ Zob. G. W. F. Hegel, System der Wissenschaft, Tl. 1: Die Phänomenologie des Geistes, s. XXXVIII. Zob. też Przedmowe do Fenomenologii ducha, s. 43.

${ }_{235}$ Zob. ibidem.

${ }^{236}$ Zob. G. W. F. Hegel, System der Wissenschaft, Tl. 1: Die Phänomenologie des Geistes, s. XV. Zob. też Przedmowę do Fenomenologii ducha, s. 20.

${ }_{237}$ Zob. G. W. F. Hegel, System der Wissenschaft, Tl. 1: Die Phänomenologie des Geistes, s. XIX-XX. Zob. też Przedmowe do Fenomenologii ducha, s. 23-24.

${ }^{238}$ Zob. G. W. F. Hegel, System der Wissenschaft, Tl. 1: Die Phänomenologie des Geistes, s. LXI-LXII. Zob. też Przedmowę do Fenomenologii ducha, s. 65-66.

${ }_{239}$ Zob. G. W. F. Hegel, System der Wissenschaft, Tl. 1: Die Phänomenologie des Geistes, s. LXII. Zob. też Przedmowe do Fenomenologii ducha, s. 66.

${ }_{240}$ Zob. G. W. F. Hegel, System der Wissenschaft, Tl. 1: Die Phänomenologie des Geistes, s. XXVIII. Zob. też Przedmowę do Fenomenologii ducha, s. 33. 
${ }^{241}$ Zob. dokładnie tytuł brzmi: System der Wissenschaft, Erster Theil: Die Phänomenologie des Geistes.

${ }^{242}$ Zob. R. Haym, Hegel und seine Zeit, „Zehnte Vorlesung. Die Lossagung von Schelling und der Romantik. Historische Construction des antiromantischen Standpunkts", s. 218-220

${ }^{243}$ Zob. G. W. F. Hegel, System der Wissenschaft, Tl. 1: Die Phänomenologie des Geistes, s. XXIX. Zob. też Przedmowe do Fenomenologii ducha, s. 34.

${ }^{244}$ Zob. R. Haym, Hegel und seine Zeit, "Zehnte Vorlesung. Die Lossagung von Schelling und der Romantik. Historische Construction des antiromantischen Standpunkts", s. 218-220.

${ }^{245}$ Zob. G. W. F. Hegel, System der Wissenschaft, Tl. 1: Die Phänomenologie des Geistes, s. XXVIII. Zob. też Przedmowę do Fenomenologii ducha, s. 33.

${ }_{246}$ Zob. G. W. F. Hegel, System der Wissenschaft, Tl. 1: Die Phänomenologie des Geistes, s. XX-XXI, XXVII-XXVIII. Zob. też Przedmowę do Fenomenologii ducha i porównaj rozważania na s. 24-27 z uwagami na s. 32-33.

${ }_{247}$ Zob. ibidem.

${ }^{248}$ Zob. R. Haym, Hegel und seine Zeit, "Zehnte Vorlesung. Die Lossagung von Schelling und der Romantik. Neue Formulirung des Princips und der Methode", s. $220-221$.

${ }^{249}$ Zob. G. W. F. Hegel, System der Wissenschaft, Tl. 1: Die Phänomenologie des Geistes, s. XX-XXI. Zob. też Przedmowę do Fenomenologii ducha i porównaj rozważania na s. $24-25$.

${ }^{250}$ Zob. G. W. F. Hegel, System der Wissenschaft, Tl. 1: Die Phänomenologie des Geistes, s. XIX-XX. Zob. też Przedmowę do Fenomenologii ducha i porównaj rozważania na s. 24.

${ }^{251}$ Ibidem.

${ }^{252}$ Zob. R. Haym, Hegel und seine Zeit, "Zehnte Vorlesung. Die Lossagung von Schelling und der Romantik. Neue Formulirung des Princips und der Methode", s. 221.

${ }^{253}$ Zob. R. Haym, Hegel und seine Zeit, "Zehnte Vorlesung. Die Lossagung von Schelling und der Romantik. Neue Formulirung des Princips und der Methode", s. 221-222.

${ }^{254}$ Zob. R. Haym, Hegel und seine Zeit, "Zehnte Vorlesung. Die Lossagung von Schelling und der Romantik. Neue Formulirung des Princips und der Methode", s. 222-223.

${ }^{255}$ Zob. R. Haym, Hegel und seine Zeit, "Zehnte Vorlesung. Die Lossagung von Schelling und der Romantik. Neue Formulirung des Princips und der Methode", s. 223-224.

${ }^{256}$ Zob. G. W. F. Hegel, System der Wissenschaft, Tl. 1: Die Phänomenologie des Geistes, s. XX-XXI. Zob. też Przedmowę do Fenomenologii ducha i porównaj rozważania na s. $25-26$.

${ }^{257}$ Zob. G. W. F. Hegel, System der Wissenschaft, Tl. 1: Die Phänomenologie des Geistes, s. XXIII. Zob. też Przedmowę do Fenomenologii ducha i porównaj rozważania na s. 29.

258 Zob. ibidem. Zob. też R. Haym, Hegel und seine Zeit, „Zehnte Vorlesung. Die Lossagung von Schelling und der Romantik. Neue Formulirung des Princips und der Methode", s. 224.

259 Zob. R. Haym, Hegel und seine Zeit, "Zehnte Vorlesung. Die Lossagung von Schelling und der Romantik. Neue Formulirung des Princips und der Methode", s. 224.

${ }^{260}$ Zob. R. Haym, Hegel und seine Zeit, "Zehnte Vorlesung. Die Lossagung von Schelling und der Romantik. Aristotelische Züge in dieser Formulirung", s. 225.

${ }^{261}$ Zob. R. Haym, Hegel und seine Zeit, "Zehnte Vorlesung. Die Lossagung von Schelling und der Romantik. Aristotelische Züge in dieser Formulirung", s. 225-226.

${ }^{262}$ Zob. ibidem. 
${ }^{263}$ Zob. R. Haym, Hegel und seine Zeit, "Zehnte Vorlesung. Die Lossagung von Schelling und der Romantik. Aristotelische Züge in dieser Formulirung", s. 226.

${ }^{264}$ Zob. G. W. F. Hegel, System der Wissenschaft, Tl. 1: Die Phänomenologie des Geistes, s. XXII. Zob. też Przedmowę do Fenomenologii ducha i porównaj rozważania na s. 28.

${ }^{265}$ Zob. G. W. F. Hegel, System der Wissenschaft, Tl. 1: Die Phänomenologie des Geistes, s. XXIII. Zob. też Przedmowę do Fenomenologii ducha i porównaj rozważania na s. 30 .

${ }^{266}$ Zob. G. W. F. Hegel, System der Wissenschaft, Tl. 1: Die Phänomenologie des Geistes, s. XXIV. Zob. też Przedmowę do Fenomenologii ducha i porównaj rozważania na s. 31.

267 Zob. R. Haym, Hegel und seine Zeit, "Zehnte Vorlesung. Die Lossagung von Schelling und der Romantik. Aristotelische Züge in dieser Formulirung", s. 228.

268 Zob. R. Haym, Hegel und seine Zeit, "Zehnte Vorlesung. Die Lossagung von Schelling und der Romantik. Kritischer Rück- und Vorbild", s. 229-231.

${ }_{269}$ Zob. ibidem.

270 Ta część wykładu Twardowskiego wsparta została na trzech pierwszych rozważaniach Hayma z wykładu jedenastego, zob. R. Haym, Hegel und seine Zeit, „Elfte Vorlesung. Die Phänomenologie. Die Phänomenologie als Versuch, den Standpunkt der absoluten Erkenntniß wissenschaftlich zu rechtfrtigen. Verbindung des transcendentalen und des historischen Beweises. Confusion dieser Verbindung", s. 232-244 , oraz na wybranych fragmentach z rozważań Fischera, zob. K. Fischer, Geschichte der neuern Philosophie, Bd. 8: Hegels Leben, Werke und Lehre, Tl. 1, Heidelberg 1901. Rozwinięcia do pracy Fischera podajemy w konkretnym przypadku.

271 Zob. G. W. F. Hegel, System der Wissenschaft, Tl. 1: Die Phänomenologie des Geistes, s. XXXII-XXXIII. Zob. też Przedmowę do Fenomenologii ducha i porównaj rozważania na s. 38.

272 Zob. K. Fischer, Geschichte der neuern Philosophie, Bd. 8: Hegels Leben, Werke und Lehre, T1. 1, Heidelberg 1901, "Zweites Buch: Hegels Lehre, Erstes Capitel: Hegels Ausgangpunkte und Aufgaben. Die Idee der Weltentwicklung, II: Das absolute Identitätssystem, 5: Der Weg zur Wahrheit", s. 230.

${ }^{273}$ Zob. R. Haym, Hegel und seine Zeit, „Elfte Vorlesung. Die Phänomenologie. Die Phänomenologie als Versuch, den Standpunkt der absoluten Erkenntniß wissenschaftlich zu rechtfrtigen", s. 235. Jeśli chodzi o pracę K. Fischera, Hegels Leben, Werke und Lehre, to Twardowski odnosi się zapewne do fragmentów poświęconych fenomenologii ducha, lecz w tym przypadku bez konkretnego wskazania miejsca.

274 Zob. R. Haym, Hegel und seine Zeit, „Elfte Vorlesung. Die Phänomenologie. Die Phänomenologie als Versuch, den Standpunkt der absoluten Erkenntniß wissenschaftlich zu rechtfrtigen", s. 235. Zob. też O. Pöggeler, Zur Deutung der Phänomenologie des Geistes, „Hegel-Studien”, Bd. 1, 1961, s. 255-294.

${ }_{275}$ Zob. R. Haym, Hegel und seine Zeit, „Elfte Vorlesung. Die Phänomenologie. Verbindung des transcendentalen und des historischen Beweises", s. 236-238.

276 Zob. W. Windelband, Die Geschichte der neueren Philosophie in ihrem Zusammenhange mit der allgemeinen Cultur und den besonderen Wissenschaften, Bd. 2, Die Blüthezeit der deutschen Philosophie. Von Kant bis Hegel und Herbart, Leipzig 1880 (2. Aufl. 1899), „II. Teil, Die Kantische Philosophie. §61. Kants ästhetische Philosophie", s. 150 i dalsze.

${ }_{277}$ Zob. R. Haym, Hegel und seine Zeit, „Elfte Vorlesung. Die Phänomenologie. Verbindung des transcendentalen und des historischen Beweises", s. 236.

${ }_{278}$ Zob. ibidem.

279 Zob. G. W. F. Hegel, System der Wissenschaft, Tl. 1: Die Phänomenologie des Geistes, s. XXXII-XXXIII. Zob. też Przedmowę do Fenomenologii ducha, s. 38.

${ }_{280}$ Zob. R. Haym, Hegel und seine Zeit, „Elfte Vorlesung. Die Phänomenologie. Verbindung des transcendentalen und des historischen Beweises", s. 236. 
${ }^{281}$ Zob. G. W. F. Hegel, System der Wissenschaft, Tl. 1: Die Phänomenologie des Geistes, „Einleitung” s. 9. Zob. też Wstęp do Fenomenologii ducha, s. 99.

${ }^{282}$ Zob. G. W. F. Hegel, System der Wissenschaft, Tl. 1: Die Phänomenologie des Geistes, „Einleitung”, s. 8-9. Zob. też Wstęp do Fenomenologii ducha, s. 98.

${ }^{283}$ K. Fischer, Geschichte der neuern Philosophie, Bd. 8: Hegels Leben, Werke und Lehre, Tl. 1, Heidelberg 1901, „Zweites Buch: Hegels Lehre, Fünftes Capitel: Die Phänomenologie des Geistes. Vorrede, Einleitung und Eintheilung, II: Enleitung, 1. Das Erkentnißvermögen als Werkzeug und Medium", s. 296-297.

${ }^{284}$ K. Fischer, Geschichte der neuern Philosophie, Bd. 8: Hegels Leben, Werke und Lehre, Tl. 1, Heidelberg 1901, "Zweites Buch: Hegels Lehre, Fünftes Capitel: Die Phänomenologie des Geistes. Vorrede, Einleitung und Eintheilung, II: Einleitung, 2: Die falsche Grundlage des Zweifels. Das erscheinende Wissen", s. 297.

285 Zob. K. Fischer, Geschichte der neuern Philosophie, Bd. 8: Hegels Leben, Werke und Lehre, Tl. 1, Heidelberg 1901, „Zweites Buch: Hegels Lehre, Fünftes Capitel: Die Phänomenologie des Geistes. Vorrede, Einleitung und Eintheilung, II: Einleitung, 2: Die falsche Grundlage des Zweifels. Das erscheinende Wissen", s. 298-299.

${ }_{286}$ Zob. G. W. F. Hegel, System der Wissenschaft, Tl. 1: Die Phänomenologie des Geistes, „Einleitung”, s. 10-11. Zob. też Wstęp do Fenomenologii ducha, s. 99.

${ }_{287}$ Zob. G. W. F. Hegel, System der Wissenschaft, Tl. 1: Die Phänomenologie des Geistes, „Einleitung”, s. 11-12. Zob. też Wstęp do Fenomenologii ducha, s. 101.

${ }_{288}$ Zob. K. Fischer, Geschichte der neuern Philosophie, Bd. 8: Hegels Leben, Werke und Lehre, Tl. 1, Heidelberg 1901, „Zweites Buch: Hegels Lehre, Fünftes Capitel: Die Phänomenologie des Geistes. Vorrede, Einleitung und Eintheilung, II: Einleitung, 2: Die falsche Grundlage des Zweifels. Das erscheinende Wissen", s. 299-300.

${ }_{289}$ Zob. G. W. F. Hegel, System der Wissenschaft, Tl. 1: Die Phänomenologie des Geistes, "Einleitung”, s. 12. Zob. też Wstęp do Fenomenologii ducha, s. 101-102.

290 Zob. K. Fischer, Geschichte der neuern Philosophie, Bd. 8: Hegels Leben, Werke und Lehre, Tl. 1, Heidelberg 1901, „Zweites Buch: Hegels Lehre, Fünftes Capitel: Die Phänomenologie des Geistes. Vorrede, Einleitung und Eintheilung, II: Einleitung, 3: Die Methode der Ausführung", s. 300 i dalsze. Cały ten fragment wywodu Twardowskiego jest streszczeniem rozważań Fischera. Podąża on w swojej argumentacji „krok w krok” za nim.

${ }_{291}$ Zob. K. Fischer, Geschichte der neuern Philosophie, Bd. 8: Hegels Leben, Werke und Lehre, Tl. 1, Heidelberg 1901, „Zweites Buch: Hegels Lehre, Fünftes Capitel: Die Phänomenologie des Geistes. Vorrede, Einleitung und Eintheilung, II: Einleitung, 2: Die falsche Grundlage des Zweifels. Das erscheinende Wissen", 3: Die Methode der Ausführung", s. 301.

${ }^{292}$ Zob. ibidem.

${ }^{293}$ Zob. ibidem.

${ }^{294}$ Zob. ibidem, s. 301-302.

295 Zob. ibidem, s. 303.

${ }_{296}$ Zob. G. W. F. Hegel, System der Wissenschaft, Tl. 1: Die Phänomenologie des Geistes, „Einleitung”, s. 18. Zob. też Wstęp do Fenomenologii ducha, s. 107.

${ }_{297}$ Zob. K. Fischer, Geschichte der neuern Philosophie, Bd. 8: Hegels Leben, Werke und Lehre, Tl. 1, Heidelberg 1901, „Zweites Buch: Hegels Lehre, Fünftes Capitel: Die Phänomenologie des Geistes. Vorrede, Einleitung und Eintheilung, III: Der Stufengang des Bewußtseins, 1: Die Hauptstufen", s. 304-305.

${ }_{298}$ Zob. K. Fischer, Geschichte der neuern Philosophie, Bd. 8: Hegels Leben, Werke und Lehre, Tl. 1, Heidelberg 1901, „Zweites Buch: Hegels Lehre, Fünftes Capitel: Die Phänomenologie des Geistes. Vorrede, Einleitung und Eintheilung, III: Der Stufengang des Bewußtseins, 2: Die triadische Ordnung", s. 305. Podane przez Twardowskiego strony są mylne. Nie chodzi tu o strony 308-309, lecz o stronę 305 z dzieła Fischera.

299 Zob. G. W. F. Hegel, System der Wissenschaft, Tl. 1: Die Phänomenologie des Geistes, „Inhalt”, s. 4-9. Zob. też Heglowski Spis treści do I wydania Fenomenologii ducha, s. 3-5. 
300 Zob. K. Fischer, Geschichte der neuern Philosophie, Bd. 8: Hegels Leben, Werke und Lehre, Tl. 1, Heidelberg 1901, „Zweites Buch: Hegels Lehre, Sechstes Capitel: Das gegenständliche Bewußtsein, II: Das wahrnehmende Bewußtsein, 1: Das Ding und die Eigenschaften", s. 309.

301 Zob. R. Haym, Hegel und seine Zeit, „Elfte Vorlesung. Die Phänomenologie. Verbindung des transcendentalen und des historischen Beweises", s. 236-238.

302 Zob. ibidem, s. 239-240.

303 Twardowski dokonuje tutaj za Haymem nagłego przeskoku i cytuje fragment kończący całą Heglowską Fenomenologię ducha. Zob. G. W. F. Hegel, System der Wissenschaft, Tl. 1: Die Phänomenologie des Geistes, s. 765. Zob. też Fenomenologia ducha, t. II, s. 428.

${ }^{304}$ Prawo biogenetyczne (biogenetisches Grundgesetz, in. teoria rekapitulacji) niemieckiego biologa Ernesta Haeckla, wygłoszone przez niego w 1866 roku w książce Zasady morfologii ogólnej organizmów (Generelle Morphologie der Organismen) (zob. E. Haeckel, Generelle Morphologie der Organismen. Allgemeine Grundzüge der Organischen Formen-Wissenschaft, mechanisch begründet durch die von Charles Darwin reformirte Descendenz-Theorie, Bd. 2: „Allgemeine Entwickelungsgeschichte der Organismen. Kritische Grundzüge der Mechanischen Wissenschaft von den entstehenden Formen der Organismen begründet durch die Deszendenz-Theorie", Berlin 1866, s. 300; a także Natürliche Schöpfungsgeschichte. Gemeinverständliche wissenschaftliche Vorträge über die Entwickelungslehre im Allgemeinen und diejenige von Darwin, Goethe und Lamarck im Besonderen, über die Anwendung derselben auf den Ursprung des Menschen und andere damit zusammenhängende Grundfragen der Naturwissenschaft, 2. verbesserte und vermehrte Aufl., Berlin 1870, s. 361-361) głosiło, że organizm w swoim jednostkowym rozwoju powiela etapy ewolucji danego gatunku. Odniesienie wiążące tezy „Fenomenologii ducha” z teorią rekapitulacji podaje Twardowski za Windelbandem.

305 Zob. R. Haym, Hegel und seine Zeit, „Elfte Vorlesung. Die Phänomenologie. Verbindung des transcendentalen und des historischen Beweises", s. 239.

${ }^{306}$ Zob. G. W. F. Hegel, System der Wissenschaft, Tl. 1: Die Phänomenologie des Geistes, s. 765. Zob. też Fenomenologia ducha, t. II, s. 428. Przywoływany przez Hegla cytat pochodzi z Schillera: Freundschaft.

${ }_{307}$ Zob. R. Haym, Hegel und seine Zeit, „Elfte Vorlesung. Die Phänomenologie. Confusion dieser Verbindung", s. 240.

${ }_{308}$ Zob. ibidem, s. 242-244.

309 Twardowski wskazuje tutaj na wykład R. Hayma z Hegel und seine Zeit, „Elfte Vorlesung. Die Phänomenologie. Die Phänomenologie nach ihrer dreisachen Bedeutung als Einleitung in das System, als dessen erster Theil und das Ganze. Gleichzeitüge Weltereignisse und Hegel's Stellung zu diesen und den Nationalinteressen", s. 244-260. W dalszej części swojego letniego wykładu korzysta też z kolejnych siedniu wykładów Hayma, lecz czyni to już tylko wybiórczo, co postaramy się wskazać.

310 Twardowski sięga do wykładu R. Hayma z Hegel und seine Zeit w sposób selektywny. Od wykładu 12 do 18 są to konkretne wskazania na całe partie lub zlokalizowane miejsca. Ważny pozostaje zwłaszcza wykład 12: „Dreizehnte Vorlesung. Die Logik", s. 292-331.

311 Odwołania do przywoływanej wielokrotnie już przez nas pracy Fischera (s. 65 nn.), podobnie jak do wykładu Hayma, występują w wykładzie letnim Twardowskiego o Heglu wraz z konkretnym przywołaniem. Poza tym sięgał on także do Windelbanda, jak i Rosenkranza, co w konkretnych miejscach próbujemy wskazać. Dodajmy, że obligował go również czas, a mianowicie ściśle wyznaczone ramy semestralne. Wykłady Twardowskiego odbywały się dwa razy w tygodniu we wtorki i czwartki od 7.00 do 8.00 rano od 6 maja 1905 roku do 6 lipca 1905 roku. Sala wykładowa była wówczas pełna, a punktualność i porządek wręcz wzorowy w wydaniu prowadzącego wykład, jak i jego słuchaczy. 